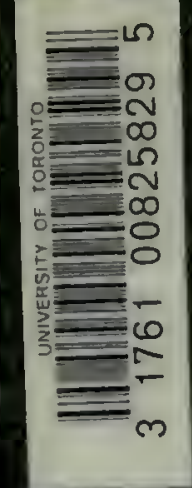



Digitized by the Internet Archive in 2008 with funding from Microsoft Corporation

http://www.archive.org/details/monographofokapi00lankuoft 


\section{MONOGRAPH OF THE}

\section{OKA PI}

m.

\section{SIR E. RAY LANKESTER, K.C.B., M.A., D.Sc., F.R.S.,}

HONORARY FELLOW OF EXETER COLLEGE, OXYORD; MEMBRE DE L'INSTTIUT DE FiRANCE (ASSOCJÉ ÉTHANGGR DE r'ACADÉMIE DES SClENCRS); EMERTUS ProfesSOR OF ZOOLOGY IN UNIYERSTTY COLLEGE, LONDON;

LATE. DIRECTOI OF THE NATURAL HISTORY I)FARTMENTS OF TUE BRTISII MUShUM;

JATE PRESIDENT OF THE BRITISH ASSOCIA'ION FOR THE ADYANCHMENT OF SCHENCE;

BATE FULLERIAN PROFESSOR OF PIIYSIOLOGY IN 'J'IIF ROYAL INSIITUTION

OF GREA'I BRITAIN; LATE MANACRE PROFESSOR OF COMLARATIVE

ANATOMY AND FELLOW OF MERTON COLLBGE, OXHORD.

\section{ATLAS}

(OF 48 PIATES)

COMPLIED WITH IILE ASSISTANCE OF

W. G. RIDEWOOD, D.SC.

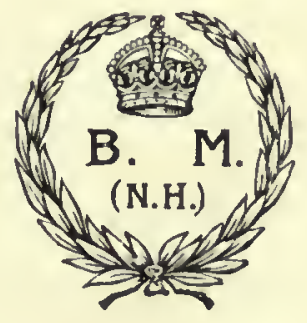

LONDON :

PRINTED BY ORDER OF THE TRUSTEES OF 'I'HE BRITISH MUSEUM.

SOLD BY LONGMANS \& CO., 39, PATERNOSTER ROW, E.C.; B. QUARITCH, 31, GRAFTON STREET, NEW BOND STREET, W.; DULAU \& CO., LTD., 37, SOHO SQUARE, W.; $A X \mathrm{~A} \& \mathrm{~T}$

THF BRITISH MUSEUAI (NA'IURAL HJSTORY), CROMWELL ROAD, S.W. 1910.

[ALI RIGHTS RESERVED]

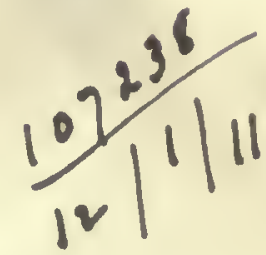


PIRINED BY ADLARD AND SON LONDON AND DORKING

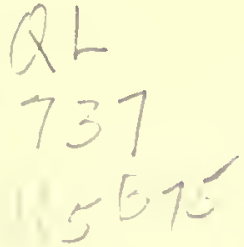




\section{PRE A A C.}

The preparation of the 'Monograph of the Okapi,' on which Sir Ray Lankester' was engaged when he retired from the Direetorship of the Natural History Departunents of the British Mrusenm, has taken longer than was expected. As the lithographic plates were printed off and the blocks originally intended for use as text-figures were. made two years ago, it was suggested that all the illustrations should be published forthwith in the form of an Atlas of Plates without waiting for the text. Sir Ray Lankester concurred cordially in this proposal, and the plates have accordingly been arranged for publication hy Dr. W. G. Ridewood, who has also written appropriate legends.

The material on which the Atlas is based consists in the first pluce of the series of skins, skulls and other bones in the British Museum, and in the second place of specimens which have been lent for the purpose of illustration and of photograplis given by musemms or private owners. Special thanks are due to Sir H. H. Johuston, G.C.M.G., the late Mr. Boyd Alexander and Major Powell-Cotton for the presentation of specimens of the Okapi, and to the Hon. Walter Rothschild, Mr. Rowland Ward, Mr. W. Eagle Clarke, and the directors of numerous foreign museums for the loan of specimens or for the gift of photographs. The figures which it has thus been possibje to put together in l'lates 1 and $29-4.6$ illustrate the variability of the skin-markings, while those of skulls shown in Plates $2-18$ constitute an important contriluntion to the discussion of the problem as to the existence of two races of Okapi, with "broad" and "narrow" skulls respectively.

$\sqrt{ }$ It is doubtful whether the Atlas will be followed by a volume of text at a later date. The necessity for publishing the text is less great than it was when the work was originally projected, in consequence of the appearance of Fraipont's large monograph in 1907, of the paper by M. de Rothsehild and H. Nenville in the present year, and of other publications on the same subject. It is hoped, however, that the illustrations will speak for themelves, and that they will be of service as a contribution to onr knowledge of the rare animal which forms the sulject of this Monograph.

SIDNEY F. HARMER, Keeper of Zoology.

Britrsh Museum (Natural History),

May, 1910. 



\section{NOTE AS 'TO T'HE OCCURRENCE AND 'I'HE ABSENCl: OF' OSSICONES IN SPECIIENS OF OKAPI, AND AS T'O BROAD AND NARROW SKULLS.}

Tun fact that very small, apparently young, "ossicones," destined to develop to full size and to become ankylosed to the skull, have been found in a full-sized specimen of Okapi (Skull C, figured in Plate 4, fig. 1, and Plate 8, fig. 1) makes it uncertain whether the presence of these structures can be rightly regarded as a character of the malc, or that their alssence is to be held as a character of the female. 'The large skull $\mathrm{C}$ (Rowland Ward's specimen purclased by the Britislı Mrusemm) is not that of an adult, althongh probably full-grown. In this specimen, as in Sir Harry Johnston's large specimen (Skull A), and in Mr. Boyd Alexander's (Skull D), the three decidnous molars of the upper jaw are still in use. The three individuals were approximately of the same age and sub-adult. In A there is no ronghness (though there is a "vascularised" patch as stated in my original description of it) on the frontal bone corresponding to the attachment of an ossicone, and lence I concluded (when describing it ten ycars ago), in view of its large size, that this individual was permanently hornless. But it is necessary to mention here that the taxidermist, who momited the skin belonging to this skull for the British Museum, found a small fibrous body on each side in the integument of the head corresponding in position to the ossicones, and I do not donbt (now that the small bony ossicones of Skull C, found in the same position, have become known to me) that these little lumps in the speeimen A wore commencing ossicones. Unfortunately they were not preserved. In Ward's specimen (Skull C) the skull is as free from any rongh growth, indicating the attachment of the ossicone on either sile, as it is in Sir Harry Jolnston's specimen (Skull A). On the other hand, the skull (D) of Mr. Boyd Alexander's specimen has a roughly marked area on each frontal bone and two fairly large but immature ossicones, which, thongh soparate, fit on to the roughened patches. I have had, it therefore appear's, no Okapi skull in my hands which was devoid of ossicones or detached commencements of them, and yet was adult or sub-adult. On the otlier hand, M. Fraipont has recorded at least one such specimen, and this (No. 489) was transmitted to the Tervueren Muscum as that of a female (Plate 16, fig. K). 'Thongh it may very possibly be the case that the adult female Okapi his no ossicones, I think that it must be regarded as still a doubtful question as to whether this is the case. Full-grown skulls witliout ossicones may develop these structures later. The rare absence of ossicones in a truly adult speeimen may be due, not to sex, but to individual variation. In marked contrast to the Okapi, the Giraffe is born with the ossicones in a soft unealcified condition 
projecting more than an inch from the head. The very late appearance of the ossieones in the Okapi is a generic eharneter, and possibly applies to the female as well as the male. At present we do not really know any characters indicating the sex of skins or skulls of Okapi. Of the series of skulls measured by me, five are markedly broader than the rest, giving, as explained in the diagrams, the indiees 198.9 (C, Ward's B. M.), $197 \cdot 7$ (J, Jolnston's smaller), 190*(O, Genoa), 189 (A, Johnston's larger), 189 (E, Powell-Cotton private collection). 'The rest range from 17: to 150 . It seemed to me at one time that possibly a difference of sex might go with the difference in breadth of skull, but I have not been able to bring any evidence in favour of that hypothesis, and, noreover, though the relation given in my measurements is a simple statement of fact, I am not satisfied with it as a eorrect expression of the eharactel of the skull which suggests the term "broadness." Any measurement of the proportion of breadth to length in Okapi skulls is complicated by the variation in the proportionate length of the premaxillæ, the nasals, the frontals, and the occipital region of the skull. Another eharacter which differs in the skulls studied by me is the form of the orbital margin, which in some cases tends to be somewhat fuadrangular, whilst in others it is more nearly circnlar. For illustrations of this structure and of the præorbital tubercle, whiel varies also in form and prominence, reference should be made to Plates $8,9,10,11$ and 12 .

The asymunctry of the skull of Okapi, especially in regard to the size and the direction of the axes of the ossicones, is noteworthy. Sometimes the right and sometimes the left ossicone is the longer (compare Plate 2 with Plate 5).

It appears that not only in the striping of the skin, but in regard to many osteological featmes such as brealth of skull, proportions of cranial bones, exact form of sutures, size of tympanie bulla, size and skewness of ossicones, early or later development of the latter, and as to many features in the proportions of the "apophyses" or processes of the vertelsa (sce Plates $23-28$ ), there is a very large range of variation in Okapis, no two specimens being closely alike. The range of variation is indicated in the illustrative figures eontained in this atlas, and seems to me remarkable. At the same time I must emplasise the fact that I have not been able to find any records of the presence or absenee of such variations in a series of specimens of any other wild nummal occurring in a limited area such as that inhabited by the Okapi, and I an unable to say (without further cxamination of series of the kind-not easily to be brought together-say, of a species of Antelope, or of lios or other such Pecorine genus) that Okapi is really exceptional in the amount of individual variation which specimens of it present.

July, 1910.

E. RAY IAANKES'TER. 


\section{LIST OF THE PLA'TES.}

Information eoneerning the Skulls A-P is given in the Explanation of I'lates 13-17, in the pages preceding Plate 13.

Plate 1.-Coloured figures of the bandoliers of Okapi skin sent to Dr. P. L. Sclater by Sir Harry Johnston in 1900 (the two co-types of Equus (?) johustoni, Sclater, now in the British Musenm), and of the hind quarters of the monnted specimens in the British Musenm presented respectively by Sir Harry Johnston and Major Powell Cotton.

Plate 2.-Coloured figures of the horns (ossicones) of Okapi skull in the Musémm d'Iistoire Naturelle, Paris. ('This skull is that denoted Skull P in the list preceding Plate 13.) $a$, in fig. 2, the line of erosion of the extremity of the ossicone; $b$, the hard white extremity of the ossicone that protrudes throngh the skin. These figures were prepared in Paris for Sir Ray Lankester under the kind supervision of Prof. Edmond Perrier.

Plite 3.-Dorsal views of Skulls A and B. Skull A is that presented to the British Mnseum by Sir Harry Johnston; the premaxilla are wanting in the actunl specimen and are drawn of a pale tint, as also in Plate 4, fig. 1, and in Plate 8. Skull B is that purchased by the British Musem of Major Powell-Cotton.

PuATE 4.-Dorsal views of Skulls C and D, and figures of ossicones of Skull C. In figs. 1a, 1 b, and $1 \mathrm{c}$ the ossicones are drawn of the natural size, not lalf natural size as stated on the plate. Skull C is that purchased by the British Musenm of Mr. Rowland Ward; Skull D is that presented to the British Musenm by the late Mr. Boyd Alexander.

Plate 0.-Dorsal views of Sknlls D and E. Skull D is that presented to the British Museum by the late Mr. Boyd Alexander; Skull E is that in Major Powell-Cotton's prirate collection.

PuAte 6.-Palatal views of Sknlls D and E. Sknll D is that presented to the British Museum by the late Mr. Boyd Alexander; Skull E is that in Major Powell-Cutton's private collection.

PLAte 7.-Palatal views of Skulls F and B. Sknll F is that in the Hon. Walter Rothschild's musenm at T'ring; Skull B is that purchased by the British Musenm of Major Powell-Cotton.

Pratre 8.-Side views of Skulls C and A. Skull C is that purchased by the British Musenm of Mr. Rowland Ward; Skull A is that presented to the British. Musenm by Sir Harry Johnston. $a$, in fig. 1 , the rudimentary ossicone in position. Compare with tigs. $1 \mathrm{a}, 1 \mathrm{~b}$, and $1 \mathrm{c}$ in l'late 4 .

Plate 9.-Side view of Skull B, and figures of ossicones and teeth of the same. Skull B is that purchased by the British Musenm of Major Powell-Cotton.

Plate 10.-Side view of Skull E, and figures of teeth of the same, and of the preorbital tubercle of Skulls B, D, and E. Sknll E is that in Major Powell-Cotton's private collection; Skull B is that purchased by the British Museum of Major Powell-Cotton; Skull $\mathrm{D}$ is that presented to the British Museum by the late Mr. Boyd Alexander. $x$, in fig. 1, the hard white tip of the ossicone which protrudes through the skin, Compare with $b$ in Plate 2, fig. 2. 


\section{LIST OF THE PLATES (continued).}

PLATE 11.-Side view of Sknll D, and figures of ossicone and teeth of the same. Skull D is that presented to the British Musenm by the late Mr. Boyd Alexander. In fig. 4 the letter $c$ has been placed too much to the right ; the canine is the left-hand tooth of the three.

Plate 12.-Side and dorsal views of Skull G. Skull G is that in the Rogal Seottish Musenm, Edinburgh.

PLATEs 13-17.-Dorsal riews of Sknlls A-P. For explanation see the pages preceding Plate 13.

Pi.ATE 18.-Dorsal riew of Skull B with ossicones in position-in Plate 3, fig. 2, the skull is drawn with the ossicones removed-and sagittal seetion of the same. Skull B is that purcliased by the British Museum of Major Powell-Cotton.

PLATE 19.-Tine diagrams showing the angles between certain bones in skults of the Ox, Elk, Okapi, Elephant, and Man.

PIATFS 20-22.-The last three cervical and first two dorsal vertebre of Okapi (Plate 20), Giraffe (Plate 21), Ox and Camel (Plate 22).

Plates 23-28. -The last cervical and first dorsal vertebre of the Okapi skeleton in the Iron. Walter Rothsehild's musenm at Tring compared with those of the skeleton in the British Musemm purchased of Major Porrell-Cotton.

PIAATES 29-40.-Leg stripes of the Okapi. For explanation see the page preceding Plate 29.

Plates 41, 42.-Bandoliers of Okapi skin, lent by Major Powell-Cotton.

Ps.ATE 43.-Bandoliers of Okapi skin, lent by Major Powell-Cotton; and head of the Okaji presented to the British Musenm by the late Mr. Boyd Alexander.

Plate 44.-Side views of the monnted specimens of Okapi in the British Museum presented respectively by Sir Ilarry Johnston and the late Mr. Boyd Alexander.

Plate 45.-Side views of the mounted specimen of Okapi in the British Musenm presented by Mijor Powell-Cotton, and that in the Royal Scottish Museum, Edinburgh.

Plate 46.-P'llotograph of a living Okapi calf, and side view of the mounted specimen of Okapi in the Hon. Walter Rothschild's musem at 'Tring.

P'IATE 47.- T'ails of Okapi.

Plate 48.-Diagrams showing the slope of the hair on the liead of the Okapi. 
MONOGRAPH OF OKAPI. PLATE 1.

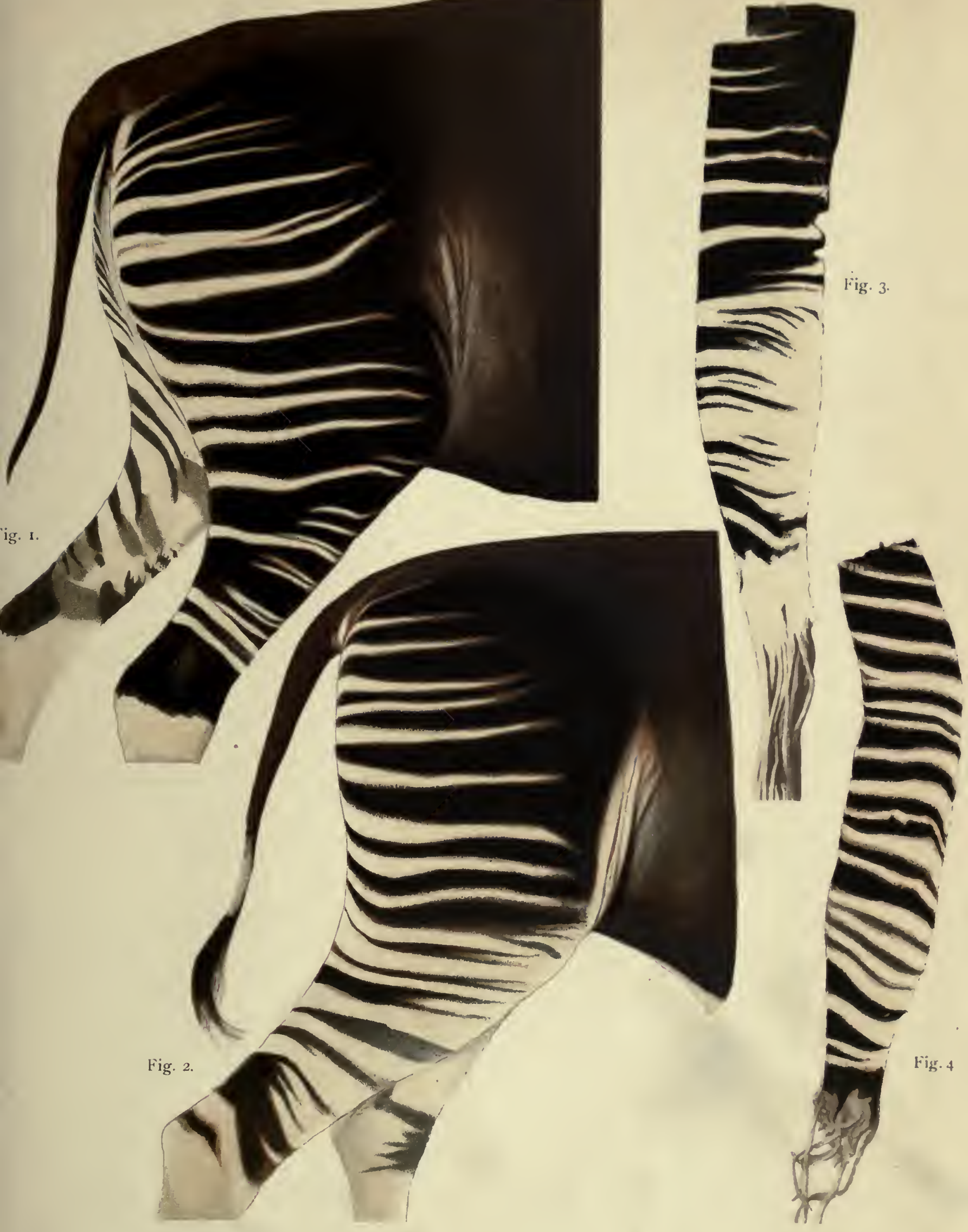

COLOUR OF THE OKAPI. 


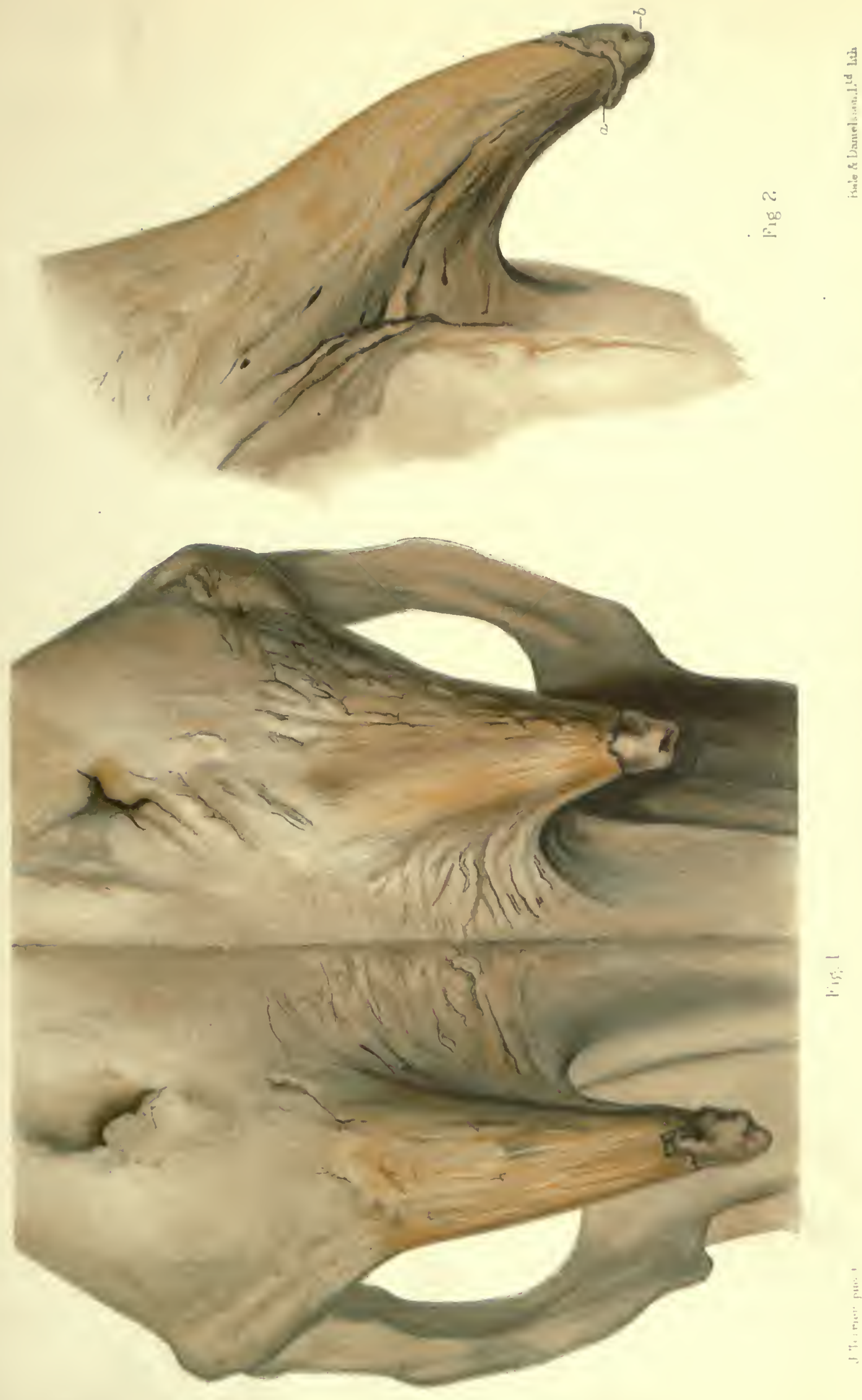

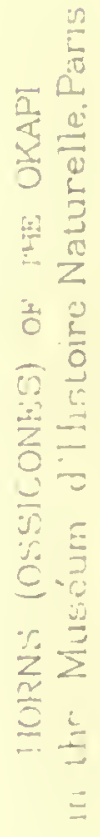



Skull A.

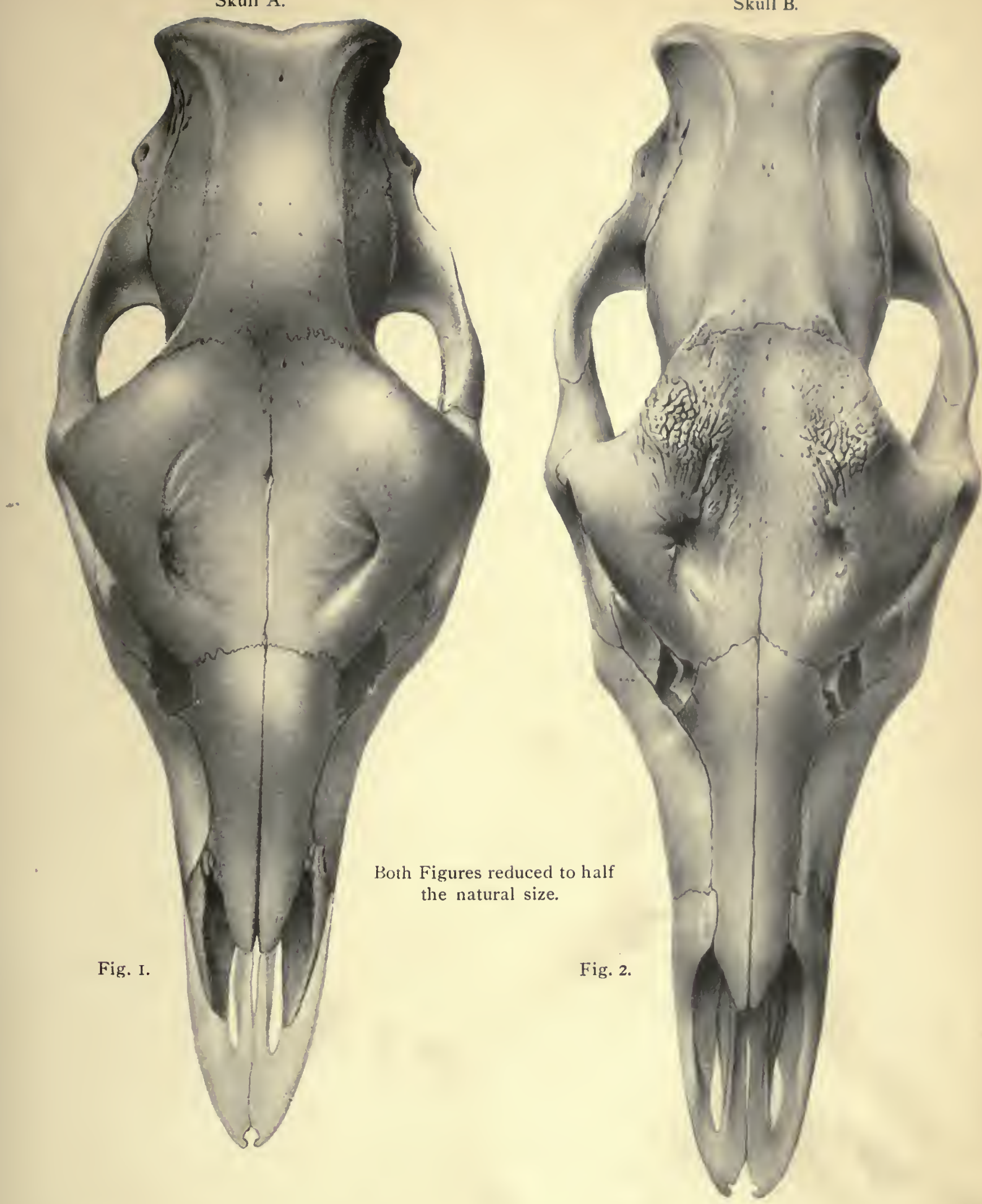

Fig. I. Skull A. Sir Harry Jolnston's specimen, presented to B.M.

Fig. 2. Skull B. Major Powell Cotton's spccimen purchased with skeleton by B.M. 

Skull C.

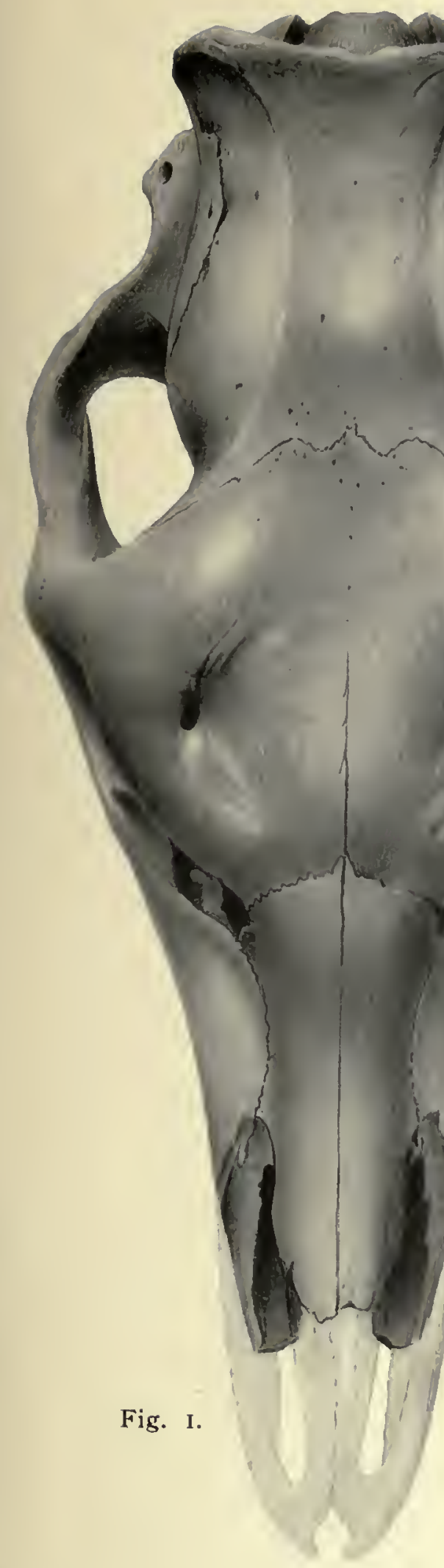

Skull D.

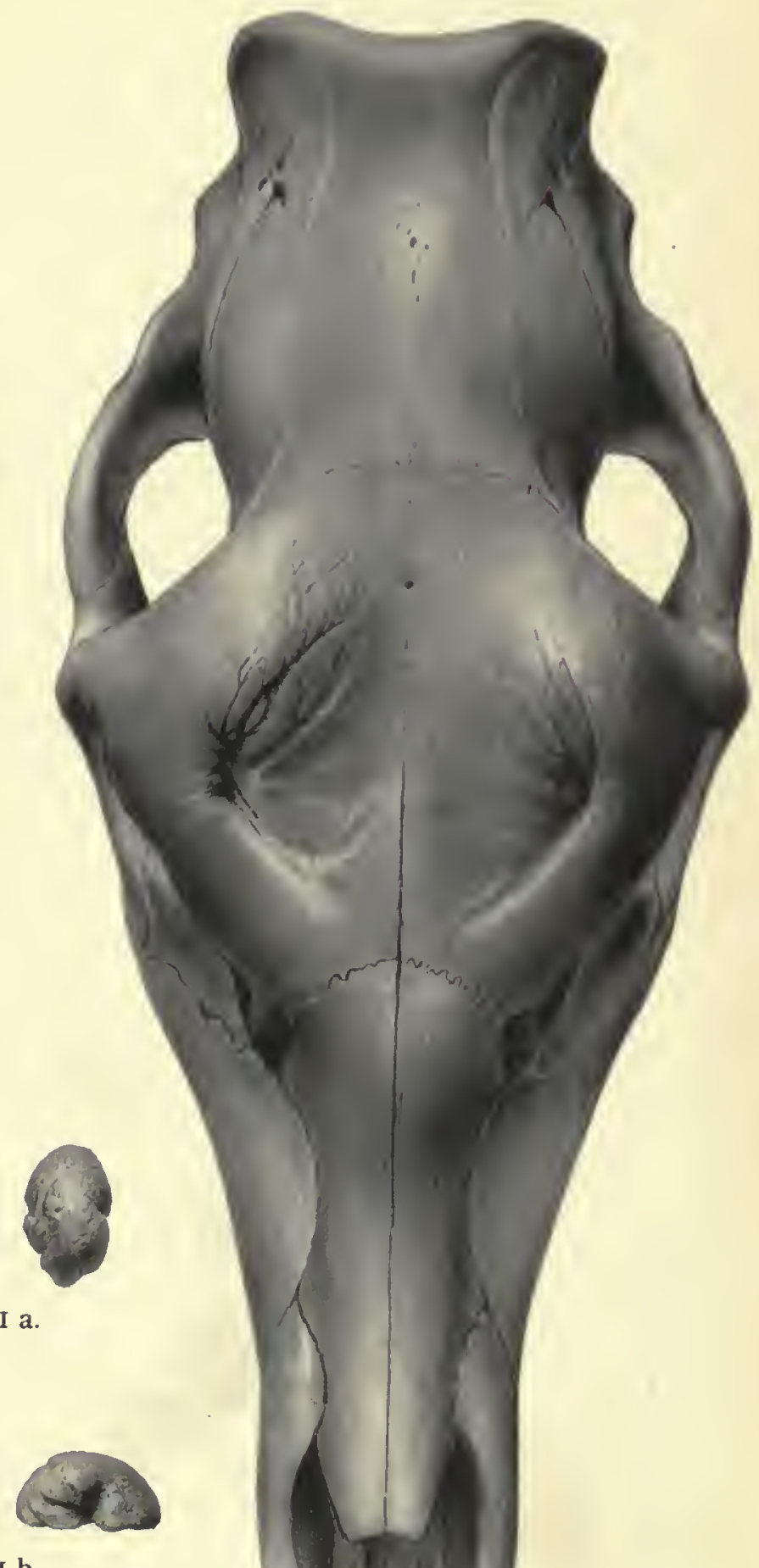

Fig. 2.

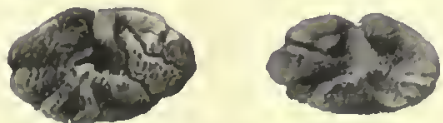

Fig. I c.

All the figures reduced to half of the natural size.

Fig. I. Skull C. Mr. Rowland Ward's Specimen, purchased by B. M.

Fig. Ia, b, c. Top, lateral and basal view of the pair of rudimentary ossicones.

Fig. 2. Skull D. Mr. Boyd Alexander's specimen presented to B. M. 

PLATE 5.

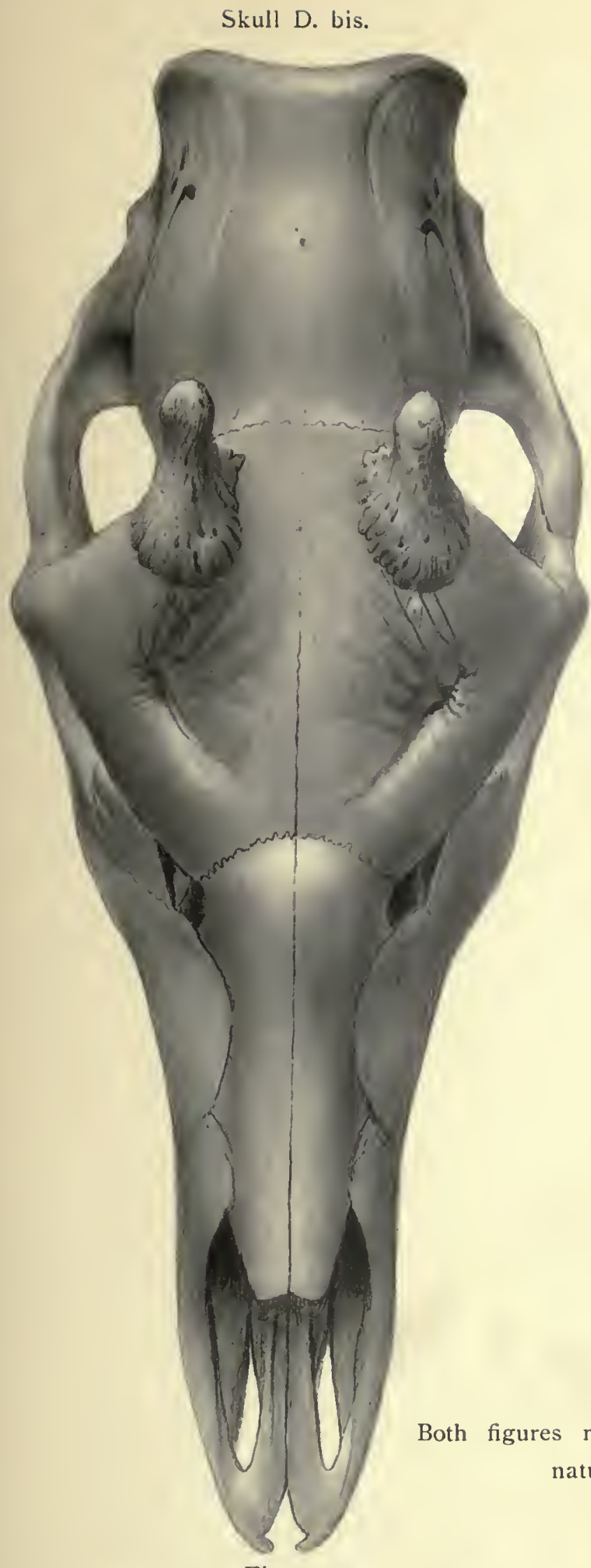

Fig. I.
Skull E.

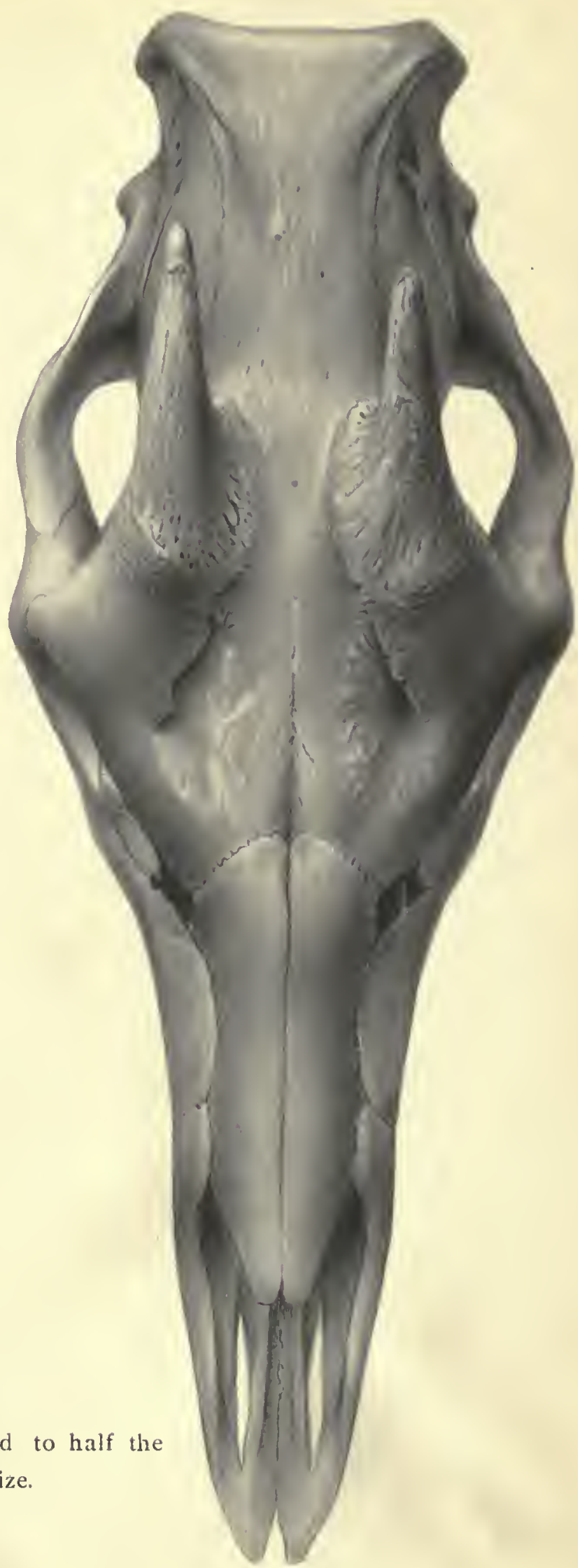

Fig. 2.

Fig. I. Sknll D. bis. Mr. Boyd Alexander's specimen with the horn-cones in position.

Fig. 2. Skull E. Major Powell Cotton's second specimen (in his private collection). 

Skull D.

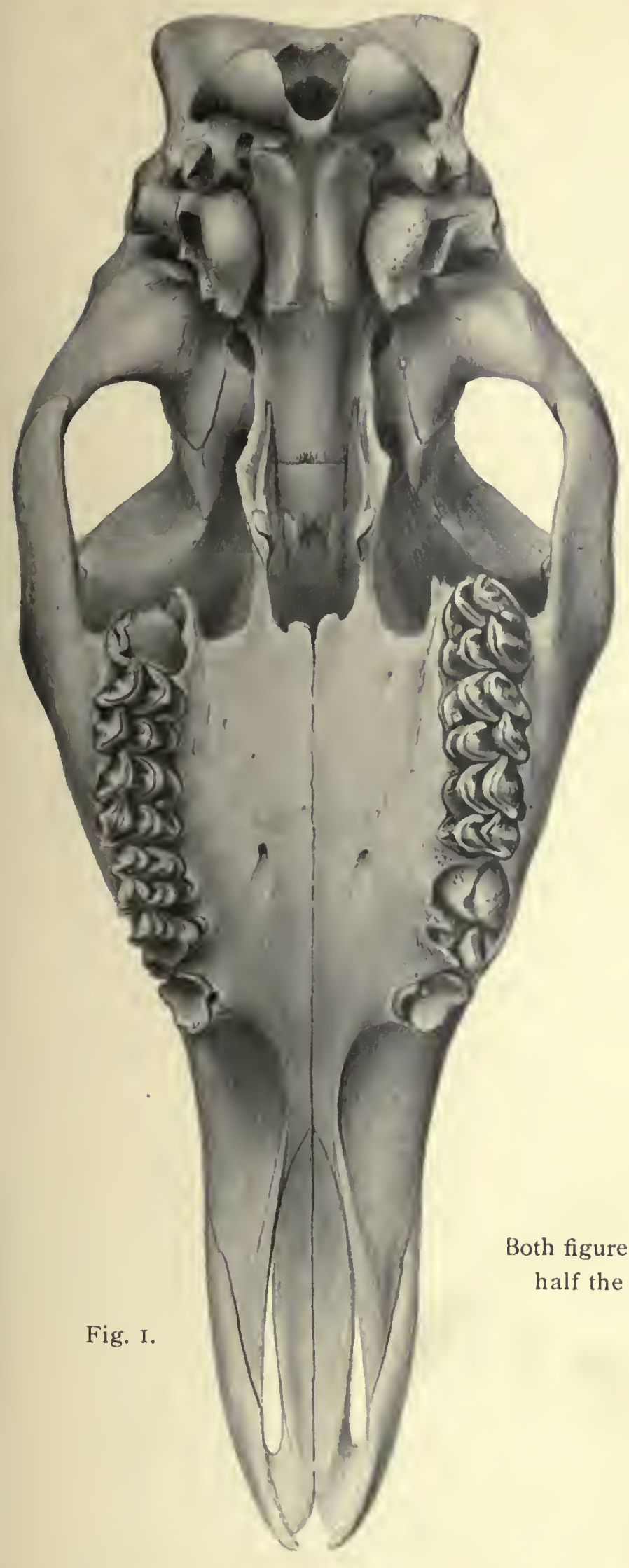

Skull E.

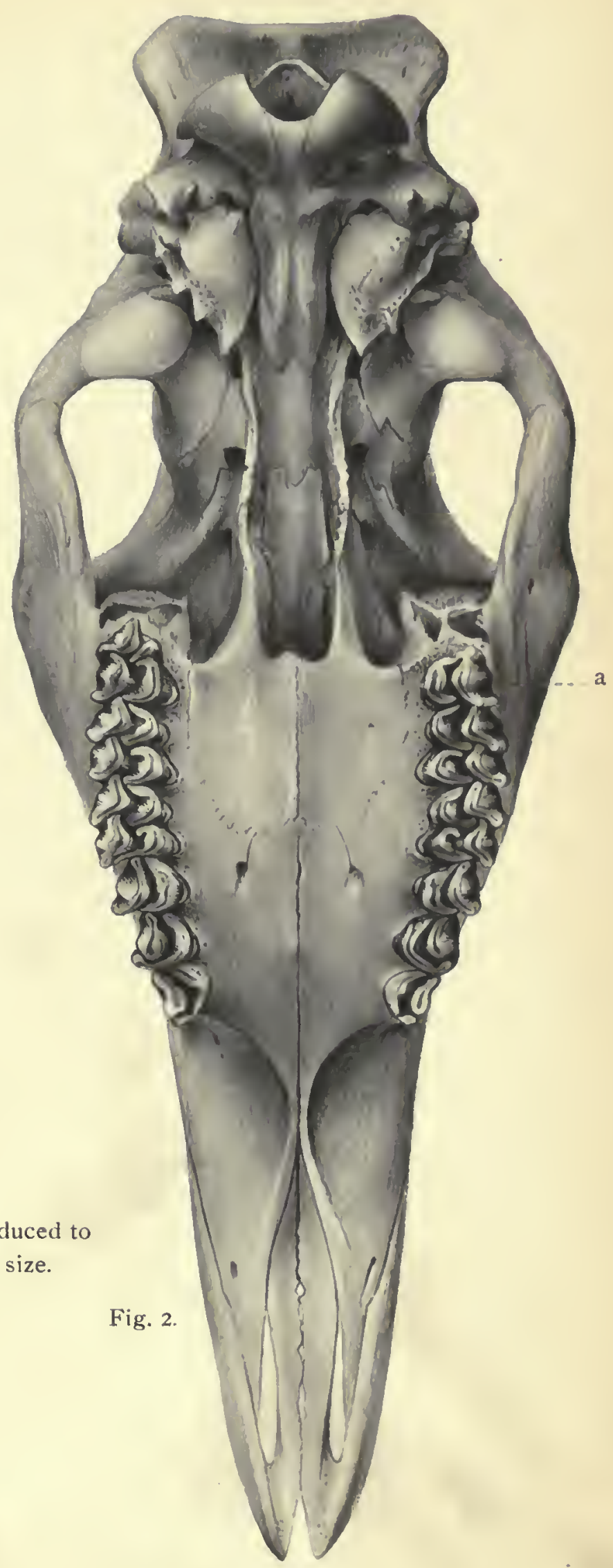

Fig. I. Skull D. Mr. Boyd Alexander's specimen presented to the B.M.

Fig. 2. Skull E. Major Powell Cotton's second specimen in his private collection. (a) The abnormal posterior molar of the right side. 

Skull F.

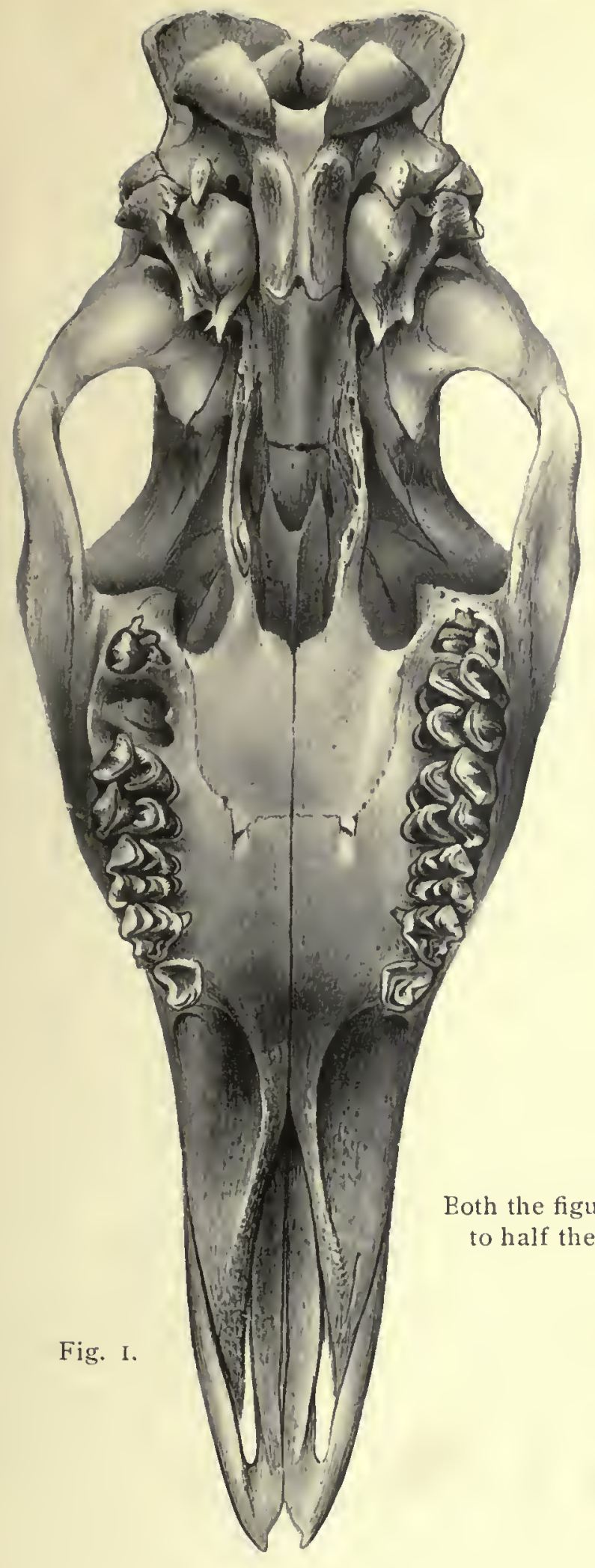

Skull B.

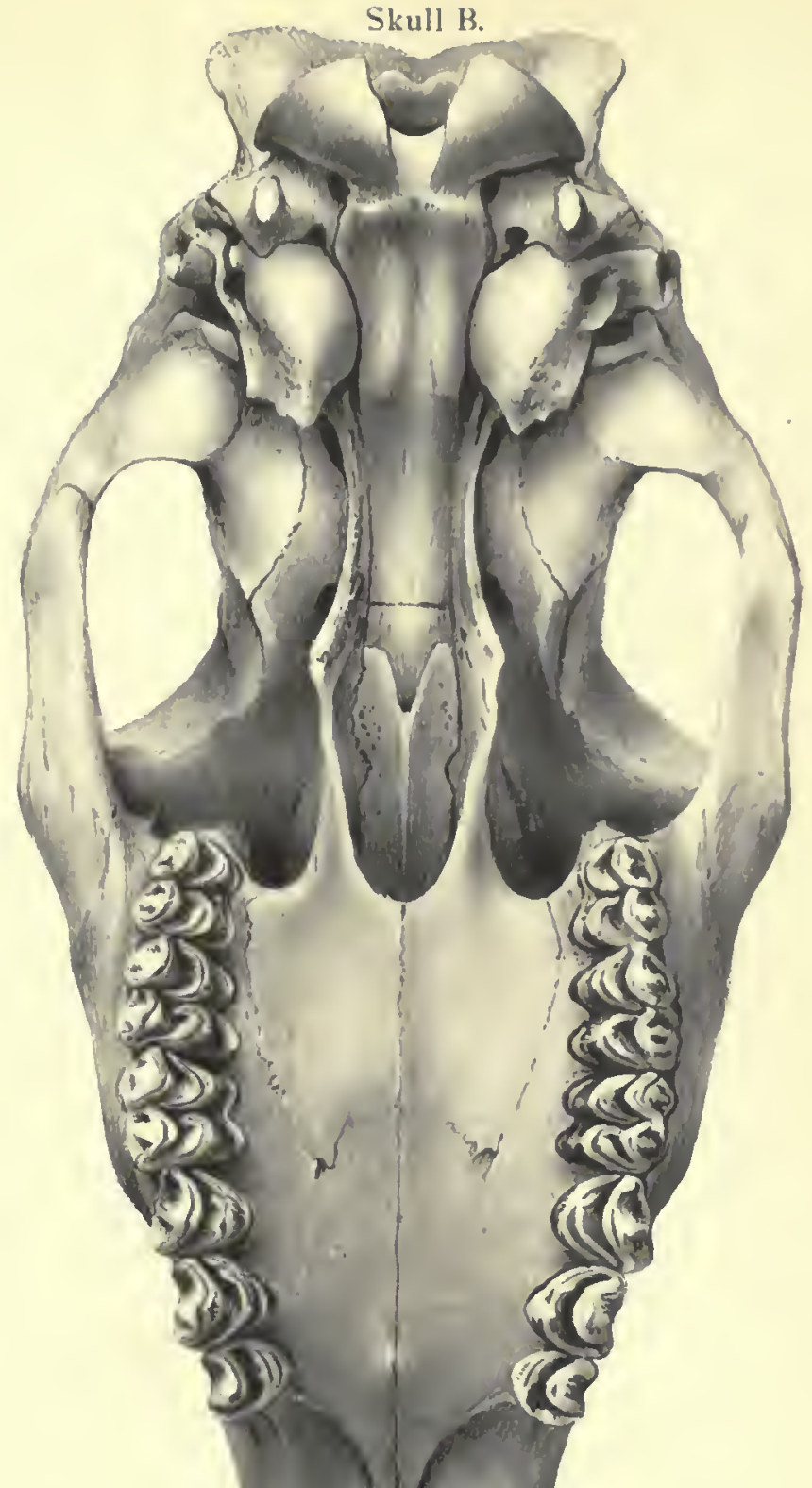

Fig. 1. Skull F. Hon. Walter Rothschild's specimen.

Fig. 2. Skull B. Major Porvell Cotton's specimen purchased by the B.M. 



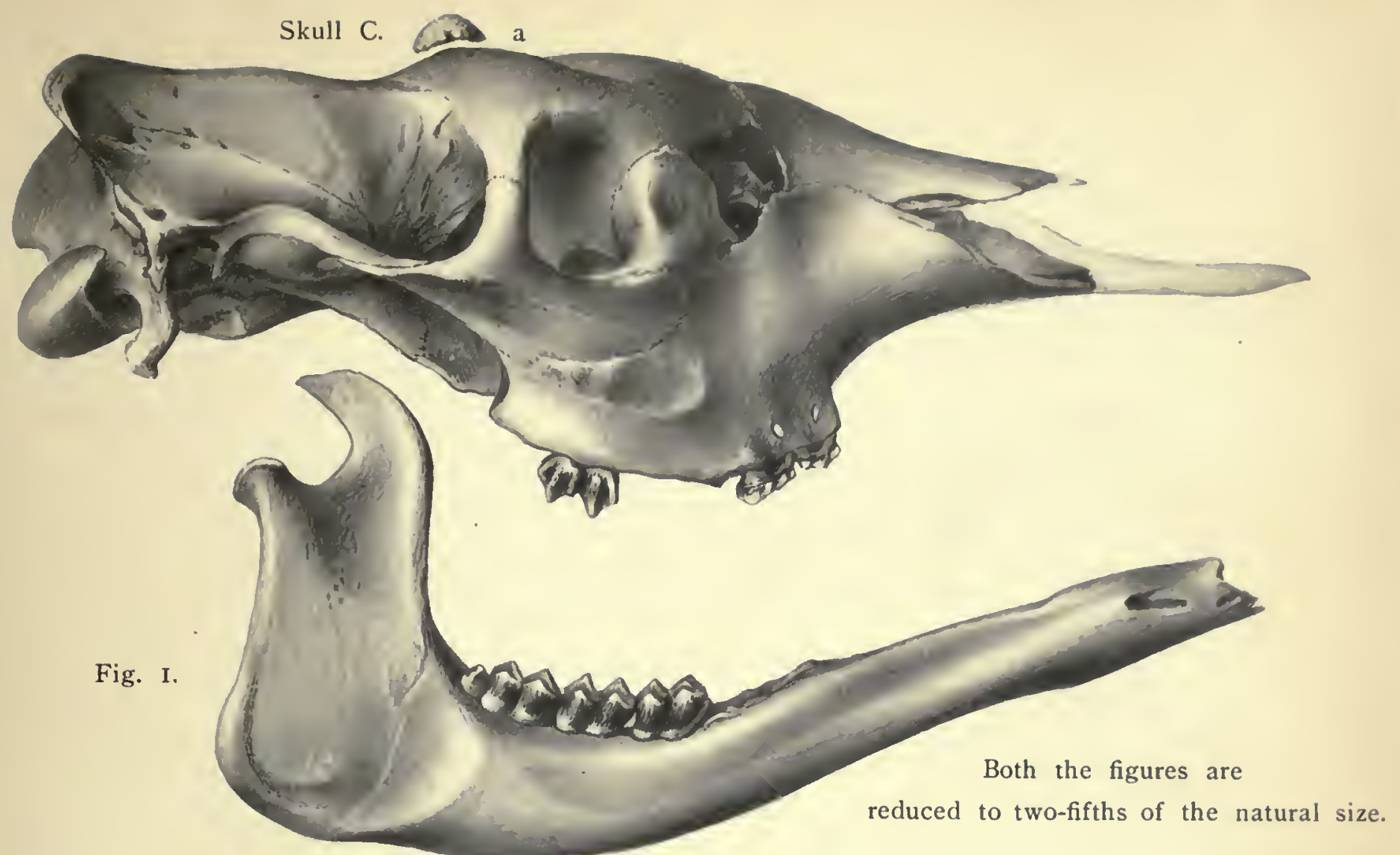

Skull A.

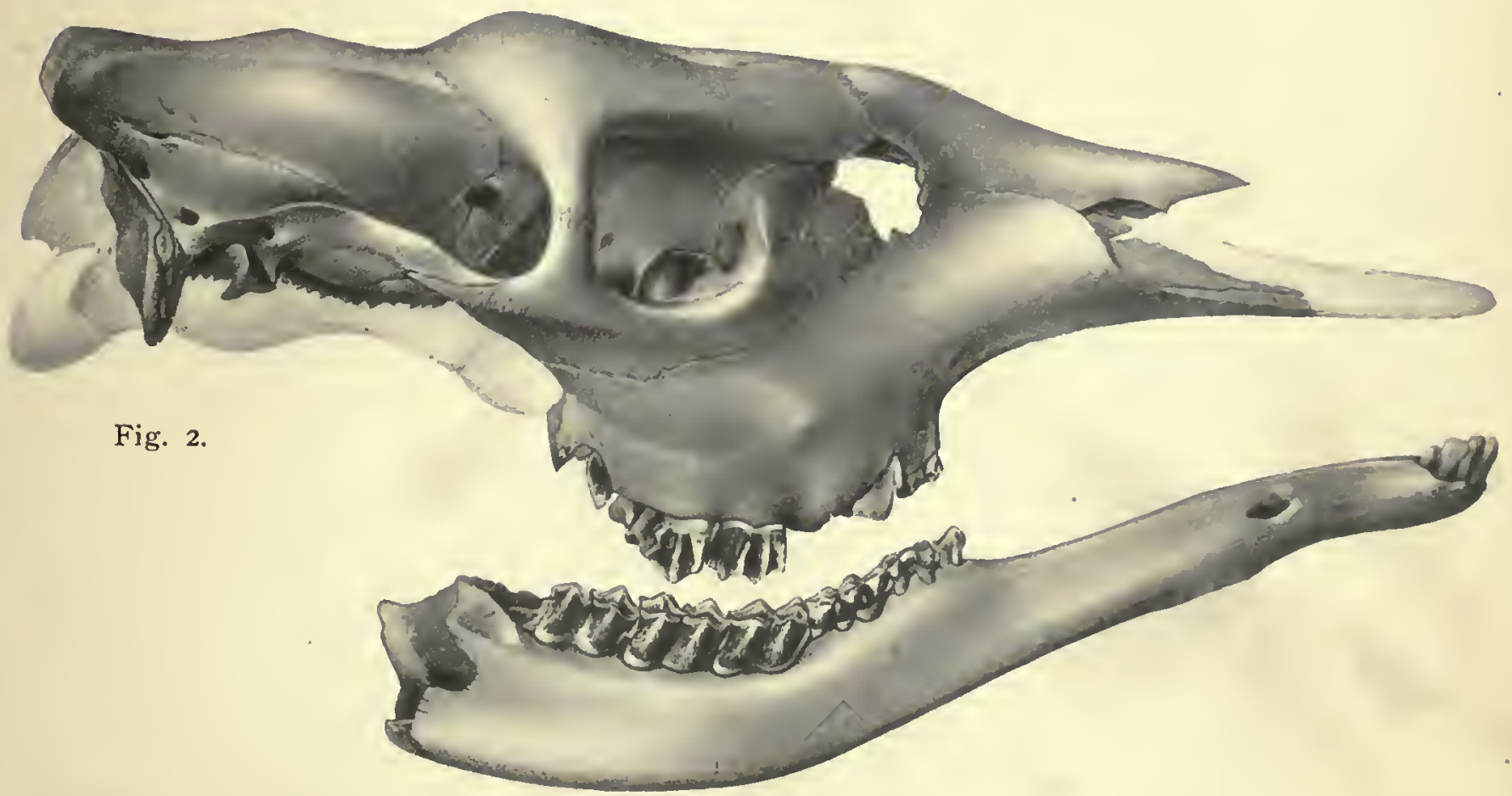

Fig I. Skull C with lower jaw, purchased by B. M. from Mr. Rowland Ward.

Fig. 2. Skull A with lower jaw, presented to B. M. by Sir Harry Johnston. 



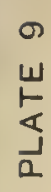

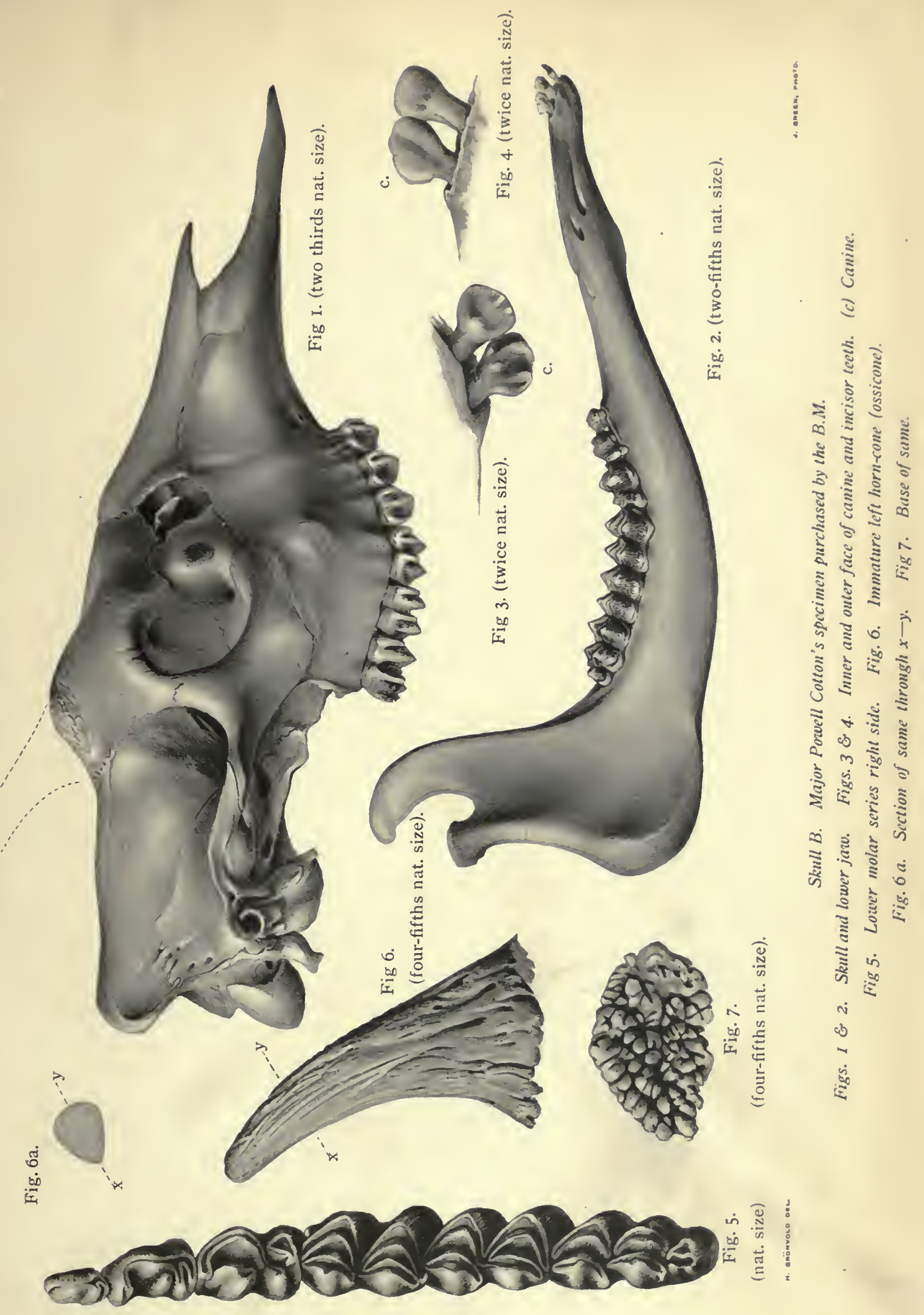





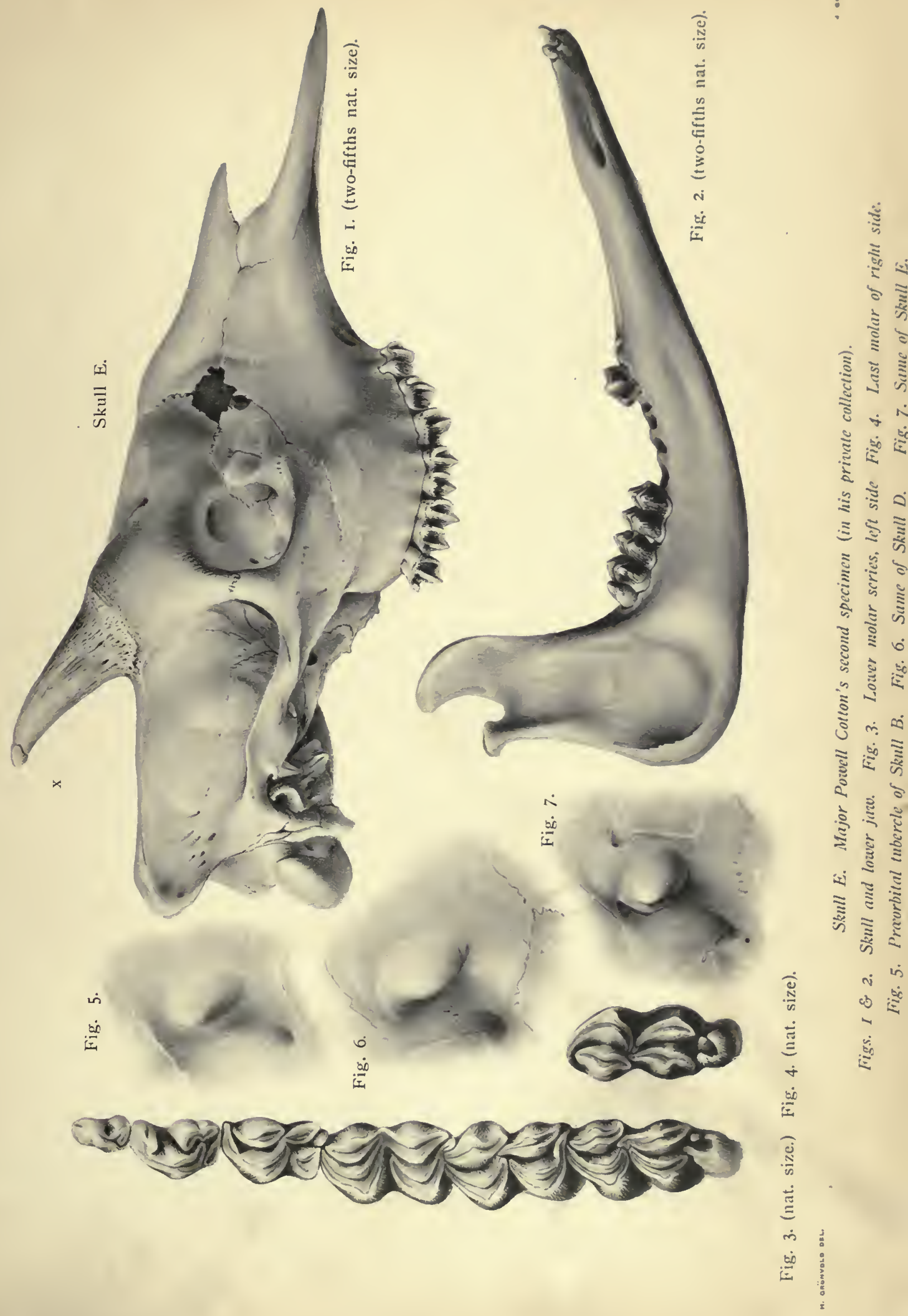





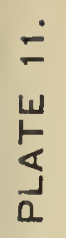
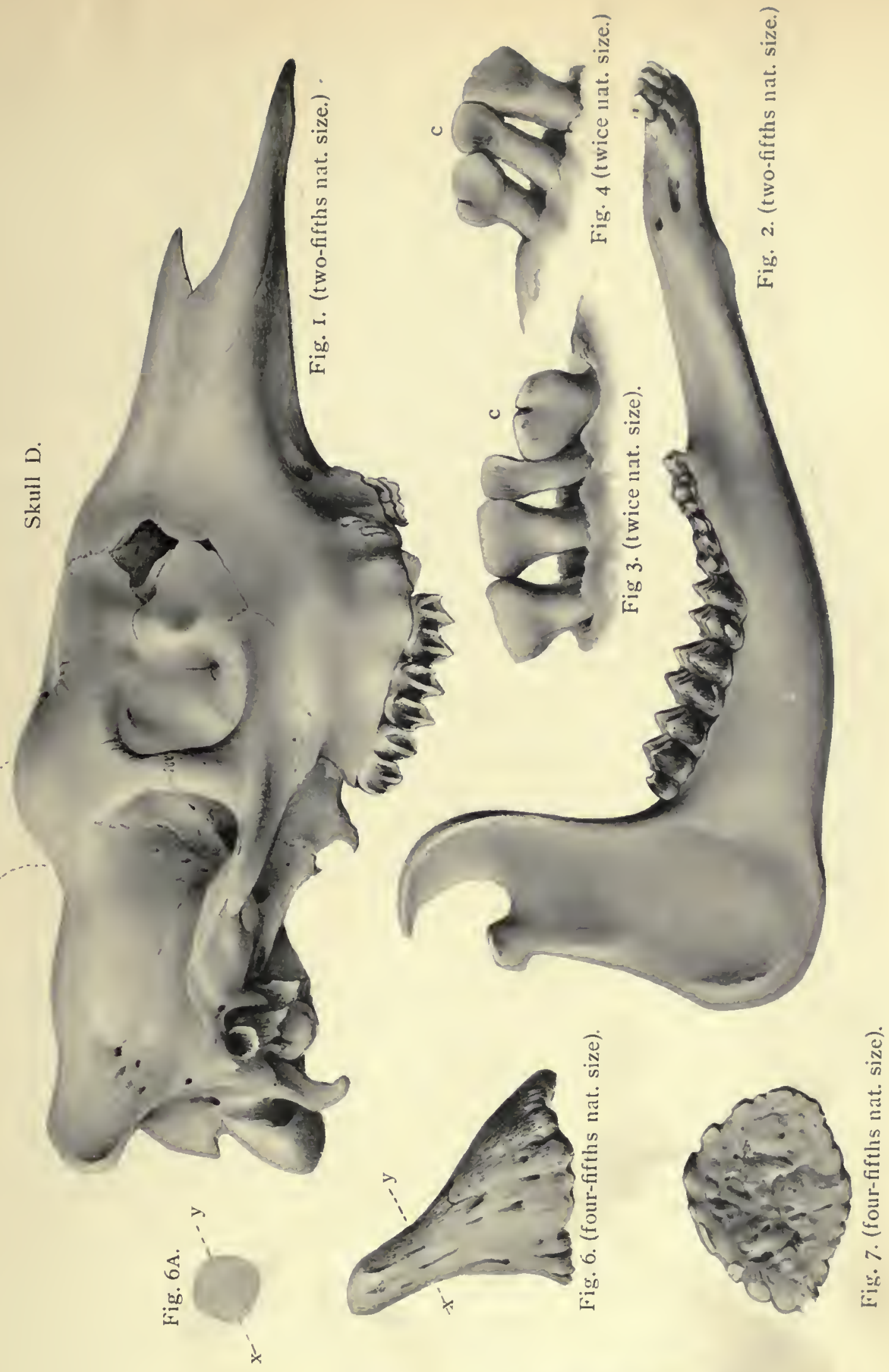

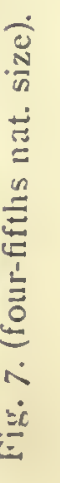

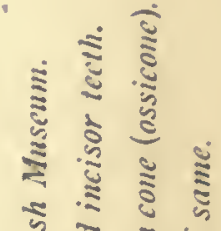

¿ $\cong$

¿

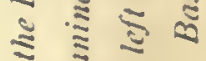

- $5 \div$

ป ะ

ฐ

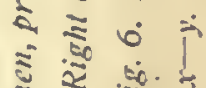

要

से

m $\dot{\Xi}$

है

है है

ग

ปิ

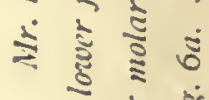

$\therefore \lesssim$

ミ

ऊ䒕

ن

क

:

cin)

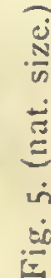





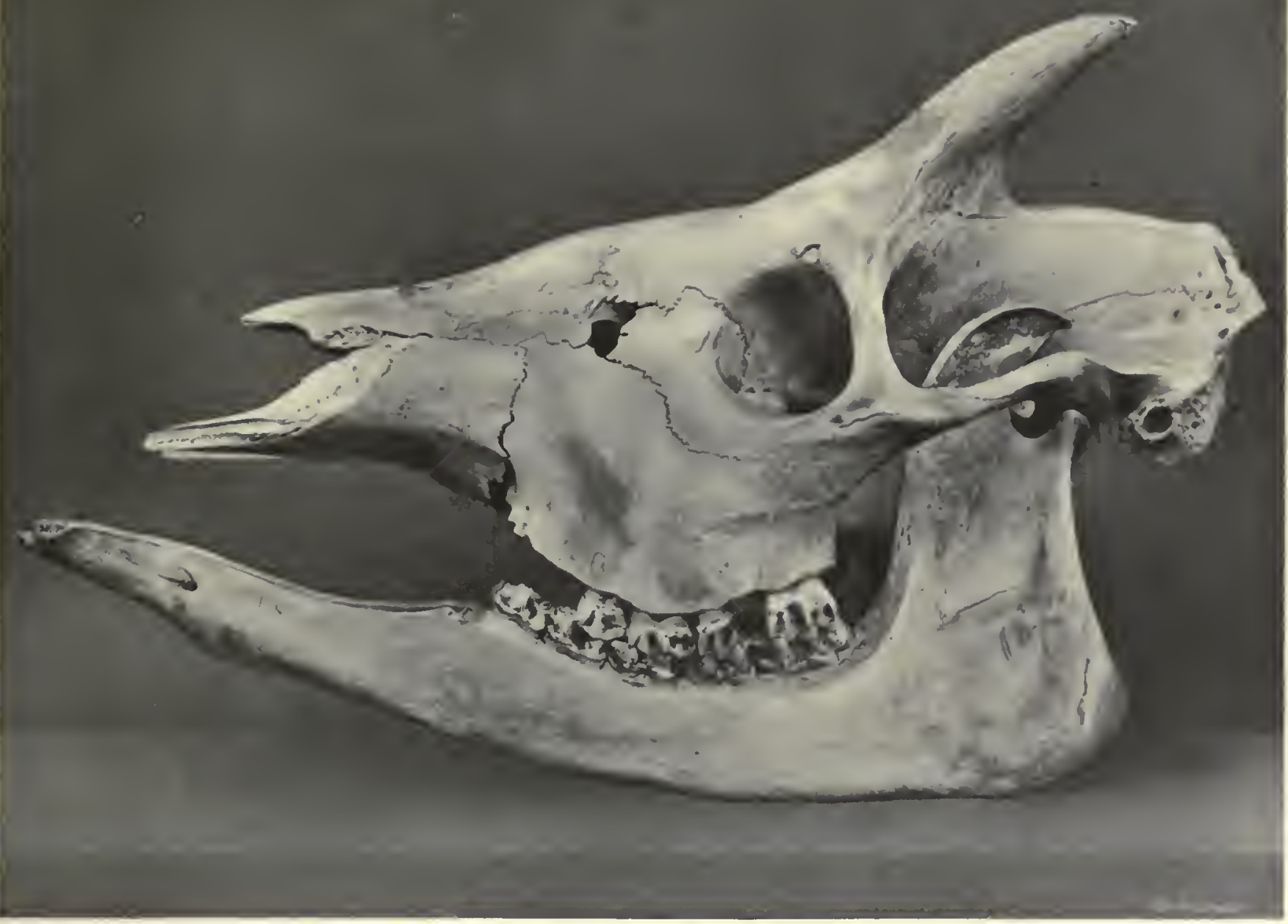

Fig. I.

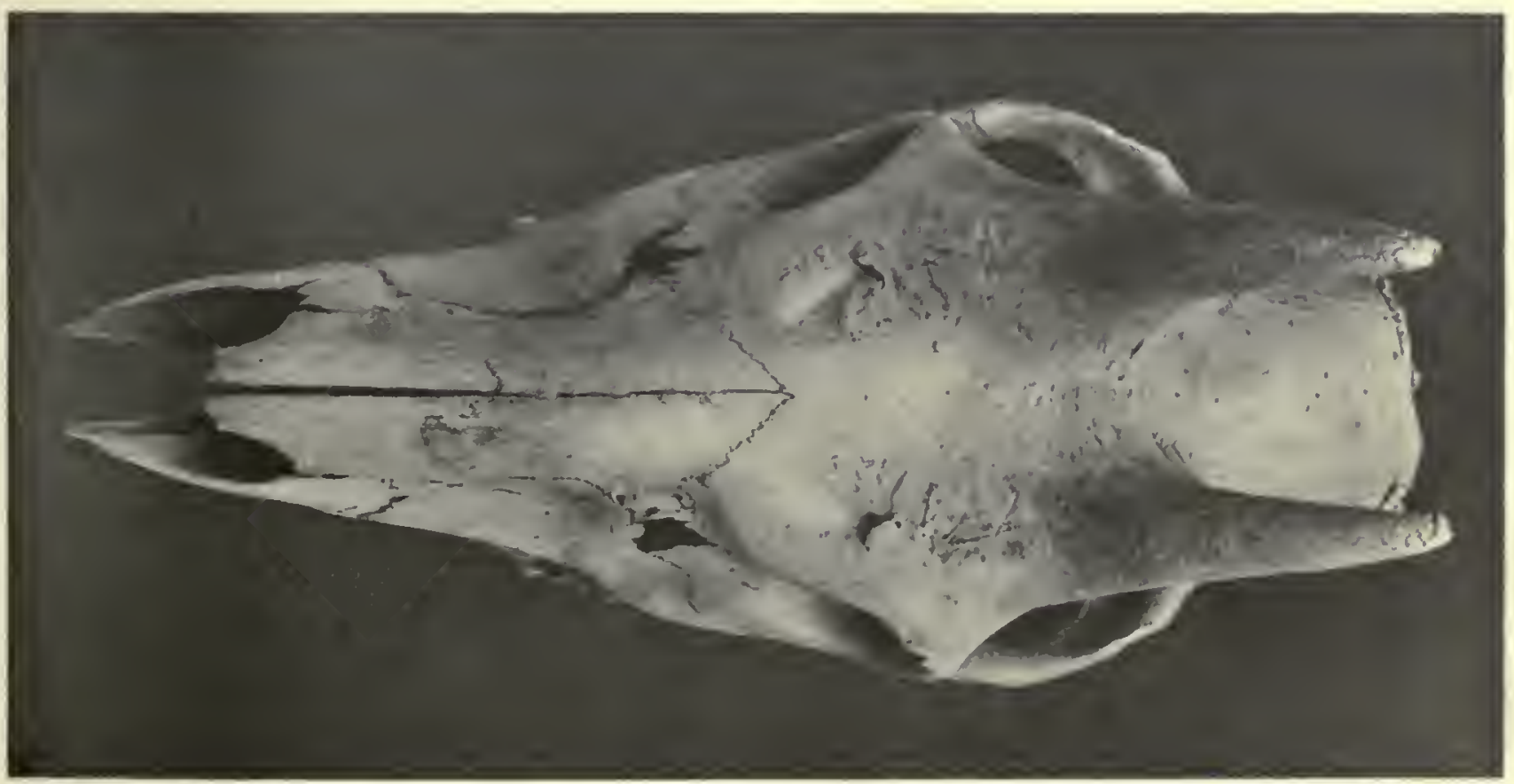

Fig. 2.

Skull G, in the Royal Scottish Museum, Edinburgh. Fig. 1. Left side view. Fig. 2. Dorsal view. Turo-fifths natural size. From photographs supplied by Mr. Eagle Clarke. 



\section{PLATES 13-17.}

The figures in Plates 13-17 show the dorsal views of fifteen skulls of the Okapi in the Britisl Museum, the Museums of Edinhurgh, 'Terveren, Rome, Madrid, Genon, and Paris, and the private collections of Major Powell-Cotton and the Hon. Walter Rothsehild, drawn mainly from photographs taken with a tolephoto lens, with the hasieranial axis of the skull set normally to the line drawn from the centre of the skull to the centre of the lens.

With a view to facilitating a comparison of the length of the nasal region of the various skulls with the postorbital breadth, for the purpose of deciding whether two types of skull, "broad" and "narrow," ean be distinguished, dotted lines have been drawn in the figures to explain the method of olotaining the ratios mentioned in the legends beneatl the figmres. The distance $\mathrm{MN}$ is the distance from the front of the suture between the nasal and premaxillary bones to the onter end of the suture between the nasal and frontal bones, that is, to the foremost point of the froutal bone. This distance gives a fair indication of the length of the facial parts of the skull. The distance from the front of the premaxillary bones wonld possibly have heen a better criterion, but. the selection of the above measurement was largely determined by the absence of the premaxilla in some of the skulls. 'The distance $\mathrm{HE}$ is the maximm width of the skull in the region of the postorbital areh. 'l'his gives a fair indication of the breadth of the skull as a whole. 'The ratio EE (or MM) to MN gives ronghly the hreadth of the skull in terms of the length of the facial parts. Thus, in skull $\mathrm{C}$ the ratio $\mathrm{EE}$ (or MM) to MN is $198 \cdot 9: 100$, in skull $B$ it is $179 \cdot 3: 100$; so that $C$ is a relatively broader skull than $B$.

The fifteen Okapi skulls specially studied are for convenience denoted lyy the letters A-P. The particulars of these, so far as concerus the illustrations published in this Atlas, are as follows:-

\section{PLATE 13.}

Skull A.-In the British Museum; Reg. No., 1.8.9.51; presented by Sir Harry Jolınston in 1901. Sex doubtful: when first described supposed to be female because of alssence of ossicones, soft rudiments of which were, however, present; young, abont two thirds grown. Locality: Semliki Forest, near Lake Albert Edward. 'The skull is figured by E. Ray Lankester, 'Trans. Zool. Soc.,' 1902, vol. xvi, plates xxxi and xxxii, and pp. 284 and 290. Figured also in Plates 3 and 8 of this Atlas. This skull, with the corresponding skin (see Plate 44, fig. 1), is the type of Okapiu erilissoni, Lankester ('Amm. Mag. Nat. Hist.,' ser. 7, x, 59, November', 1902, p. 417).

Skull B.-In the British Museum; Reg. No., 6.12.27.1 ; part of a complete skeleton 
purehased of Major Powell-Cotton in 1906. Definitely stated by Major Powell-Cotton to be male, not quite alult. Locality : Itmi Forest, Makala. 'This skull is figmred also in Plates 3, 7, 9, and 18. 'The right ossicone is figured by E. Ray Lankester', 'Proc. Zool. Soc.' 1907, plate vii. 'The skin corresponding with this skull is that shown in Plate tis, fig. 1.

Skull C.-In the British Museum; Reg. No., 7.12.25.1; purchased of Mr. Rowland Warl in 1907. Young; sex doubtful; the skin is mounted as though male; see Plate 32, fig. 1. Locality; Ituri Forest. 'This skull is also figmred in Plates 4 and 8 . 'The ossicone is figured by E. Ray Lankester, 'Proc. Zool. Soe.'’ 1907, p. 128.

\section{Pra'l'e 14.}

Skull D.-In the British Museum; Reg. No., 7.7.8.264; presented by the late Mr. Boyd Alexander in 1907. Young male; the body was examined by Mr. Boyd Alexander' (see 'From the Niger to the Nile' ii, London, 1907, p. 26t). Loeality : Welle River, near the northern border of the Congo Free State. This skull is figured also in Plates 4, 5, 6, and 11. The ossieone is figured by E. Ray Lankester, 'Proe. Zool. Soe.,' 1907, p. 13t. 'The skin corresponding with this skull is that figmred in Plate 4t, fig. 2.

Skull E.-In Major Powell-Cotton's private collection. Adult male. 'Taken alive in a pit between the 20th and 30th of September, 1906, at two hours' march from the chief Akmupi's village of Maliangi, on the north side of the River Lindi, and opposite to the post of Makala. 'This skull is figmed also in Plates 5, 6, and 10 .

Skull F.-In the Hon. Walter Rothschild's musemm at Tring. Young, sex doubtful. Locality: unknown. 'The skull is part of a nearly complete skeleton. Figured also in Plate 7. The skin corresponding with this skull is that figured in Plate 46, fig. 2.

\section{PLA'TE 15.}

Skull G.-In the Royal Scottish Museum, Edinburgh. The skin is mounted as thongh the animal were male; the sex, however, is doubtful; adult. Loeality: Ituri Forest. 'The skull is also figured in Plate 12. A small figure of the skull is published in R. Lydekker's 'The Game Animals of Africa,' 1908, p. 379, fig. 79. 'The ossicone is figmred by E. Ray Lankester, 'Proc. Zool. Soc.' 1907, p. 131, and plate vi. The skin corresponding with this skull is that figured in Plate 45, fig. 2.

Skull H.--In the British Museum; Reg. No., 7.12.25.2; a cast purchased of Mr. Rowland Ward in 1907; the actual skull went to America. Supposed to be male, but sex doubtful; adult. Locality: doubtful. The ossicone of this skull is figured by E. Ray Lankester, 'Proc. Zool. Soc.,' 1907, plate vi, figs. 9-12.

Skmll .J.-In the British Musemm; Reg. No., 1.8.9.52: presented by Sir Harry Johnston in 1901. Sex doubtful; young. Locality: Semliki Forest, near Uganda frontier, $4000 \mathrm{ft}$. 'This is the smaller of the two skulls presented by Sir Harry Johnston, the other being Skull A. It is figured by E. Ray Lankester, 'Trans. Zool. Soc.,' 1902, vol. xri, plates $\mathrm{xxxi}$ and $\mathrm{xxxii}$. 


\section{Plate 16.}

Skull K.-In the Tervueren Muscum (Musée du Congo), Belgium; the skull of a complete skcleton, No. 489. Suid to be female, adult. Locality: Ituri Forest. 'This skull is figured by C. I. Forsyth Major, 'Proc. '/ool. Soc.', 1902, vol. ii, p. 34., tcxt-fig. 63, and by J. Fraipont, 'Annales du Musée du Congo, Zool.,' ser. 2, vol. i, “Okapia,” 1907, plates $\mathrm{v}$ and vii. The figure of Skull $\mathrm{K}$ in Plate 16 is from Forsyth Major's figure. Although obtained at the same time as skin No. 488, now at Rome (sec Plate 33, fig. 1), the skeleton No. 489 is apparently from a differcnt animal (sce Fraipont, p. 14, paragr. 5).

Skull L.-In the British Museum; Reg. No., 7.12.26.1; a cast of a skull in the Tervneren Museum (Musée du Congo), Belgium; the skull of a complete skeleton, No. 480. Said to be male, adult. Locality: Mundalah, on the road from Mawamli to Beni. The skull is fignred by C. I. Forsyth Major, 'Proc. Zool. Soc.,' 1902, vol. ii, p. 73, text-fig. 7, and p. 343, text-fig. 64; by E. Ray Lankester', 'Trans. Zool. Soc.' vol. xvi, 1902, p. 304, text-fig. 15; and by J. Fraipont, 'Annales du Muséc du Congo, Zool.,' ser. 2, vol. i, "Okapia," 1907, plates iii, iv, and vi, and text-fig. 46 on page 40 bis. A figure of the extremity of the ossicone is given by E. Ray Lankester', 'Proc. Zool. Soc.,' 1907, p. 126, text-fig. 49. Skull L is the type of Olerpia lielnechtsi, Major. 'The distinctive characters of the species are given in 'La Belgique Coloniale, Ann. viii, No. 4.5, November 9th, 1902, p. 533 ; but the figure of the skull in the 'Proc. Zool. Soc.,' 1902, vol. ii, p. 73, illustrating remarks made by Dr. Forsyth Major at the Society's meeting on June 3rd, 1902, and published in October, 1902, bears the name Olictia liebrechtsi, Maj., and stands as the basis of the species. The skin mentioned by $\mathrm{Dr}_{1}$. Forsyth Major on the same occasion is now monnted in the Stockholm Musenm. The right fore and lind legs of this are shown in Plate 39, fig. 1.

Skull M.-In the Zoological Museum of the University of Rome. Sex doubtful, adult. Locality: Itmi Forest. T'he skull of a complete skeleton clescribed and figured by A. Carruccio, 'Boll. Soc. Zool. Ital.,' ser. 2, rol. iv, 1908, pp. 1-20 and 101-116, and vol. vi, 1905, pp. 177-190. The skeleton is apparently not that of the same animal as the skin mounted at Rome, of which the legs are figured in 1'late 33, fig. 1. According to J. Fraipont ("Annales du Musée du Congo, Zool.,' scr. 2, vol. i, "Okapia," 1907, p. 14, paragr. 5 and 6) the skin given to the King of Italy is No. 488 and the skeleton No. 500. The figure of Skull M in Plate 16 is from a photograph supplied by the University of Rome.

\section{Prate 17.}

Skull N.-In the Madrid Muscum; the skull of a complete skeleton, apparently the skeleton corresponding with the skin No. 536 mounted in the 'l'orveren Museum, of which the legs are figured in Plate 37, fig. 2. See J. Fraipont, "Annales du Musée du Congo, Zool.,' ser. 2, vol. i, "Okapia," 1907, p. 14, parag. 10. Skull $\mathrm{N}$ is withont horns, and clearly does not correspond with the horned skin mounted in the Madrid Museum (skin No. 705a of J. Fraipont, p. 14, fig. 7), of which the legs are figured in Plate 34, fig. 
2, and Plate 3.5, fig. 3 of this Atlas. 'The figure of Skull $\mathrm{N}$ in Plate 17 is from a photograph supplied by the Madrid Musemm.

Skull O.-In the Genoa Musenm. From a photograph supplied by the Genoa Musenm. Skull O is without horns, and is evidently not the skull of the same animal as the skin mounted in the Genoa Musemm, of which the legs are fignred in Plate 34, fig. 1.

Śkull P.-In the Paris Museum (Muséum d'Histoire Naturelle). 'The skull of a complete skeleton. From a plotograph supplied by the Paris Museum. The ossicones are figured in Plate 2. 'The skull is figmed by M. de Rothschild and H. Neuville, 'Ann. Sei. Nit., Kool.,' rol. x, Xos. 1 and 2, 1909, pp. 15, 22, and 29. Apparently this is not the skull corresponding with the monnted skin in the Paris Musem, of which the legs are figrured in Plate 3.5, fig. 1; for althongh in the paper by Rothschild and Nenville the skeleton and skin are regarded as from the same animal (p. 2, "Un seul spécimen . . . l'Anatomie comparce"), Frapont states that the skeleton (No. 501) corresponding with the Parris skin (No. 503) went to Stockholm, and that the skin (No. 5:34) corresponding with the Parris stseleton (No. 535) is at 'Tervueren ("Annales du Musće du Congo, Zool., ser. 2, vol. i, "Okapia," 1907, p. 14, paragr. 7 and 9). In this case Skull P corresponds with the legrs figured in l'late 38 , fig. 2.

Eleven of the ahove fifteen skulls were examined at the British Museum (Natuml History), and the relative ages of these may be approximately determined by the following particular's of the dentition and sutmes. $J$ is elearly the youngest of the series; the deciduons molars are only moderately worn, and the third true molar has not yet developed. $\mathrm{F}$ is somewhat older than $\mathrm{J}$; the three deciduous molars are in use, the third molar is present, but his not yet cut the gum. C is older still; the three decifluons molars are in use, the third molar has cut the grm and is slightly wom. A and D are almost of the same age as (', but a little oleler; the third molar shows rather more signs of wear. 'The three deciduons molar's are still in use in both. In the extent of wear of the hindermost molar tooth in the lower jaw, and in the fact that the left permanent emine is alleady in use, D would alperer to loe slightly older than A; but in D the third decidnons incisor has not been shed, whereas in $A$ it has, and the posterior or fifth cusp of the third molar in the lower jaw is not so freely exposed as in A.

In the following skulls there are no milk teeth remaining. B is a little older than A and I), and E, G, H, K and L ale the oldest of the series, and hardly distinguishable the one from the other as regards age. In $B$ the horns or ossicones ane not yet ankylosed to the skull, and the parieto-frontal sutme is very distinct. In E, G, H and L the ossicones ane fused on, and the parieto-frontal suture is obliterated. In $K$ there are no ossicones, and the parieto-frontal suture is obliterated. In E and H the lachrymo-malar and fronto-malar sutures persist; in $K$ the lachrymo-malar.sutme is present, but not the fronto-malar; in $\mathrm{G}$ and $\mathrm{L}$ both have disappeared. 
0

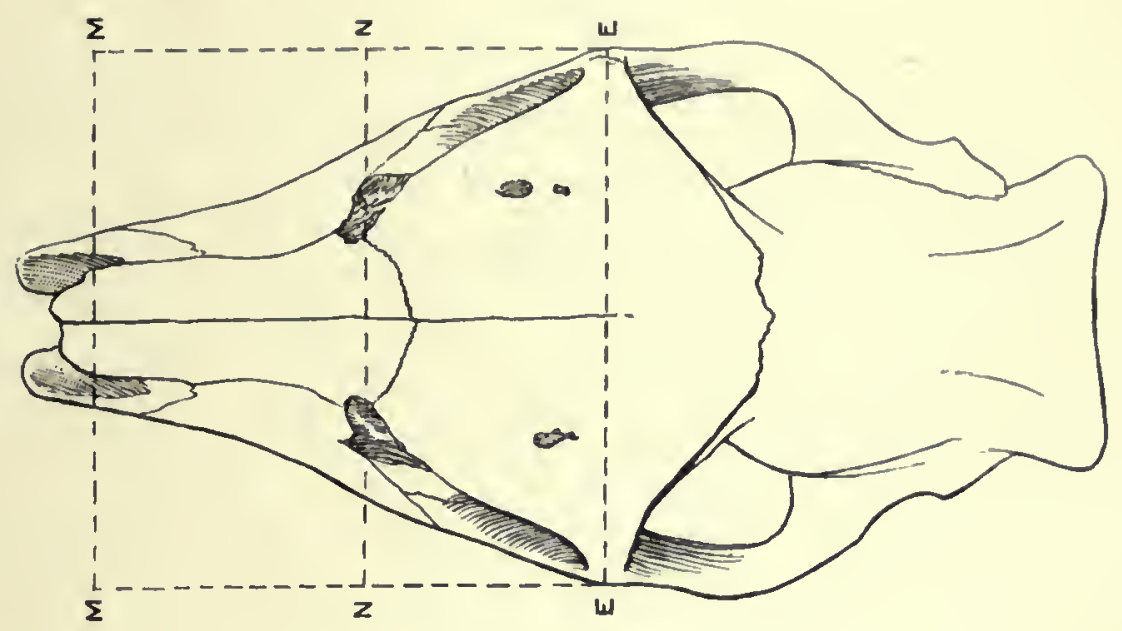

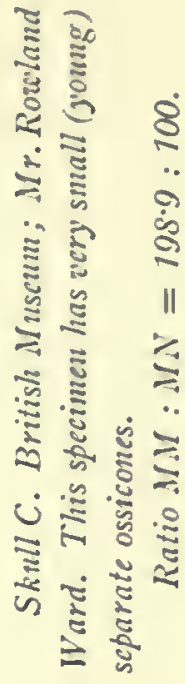

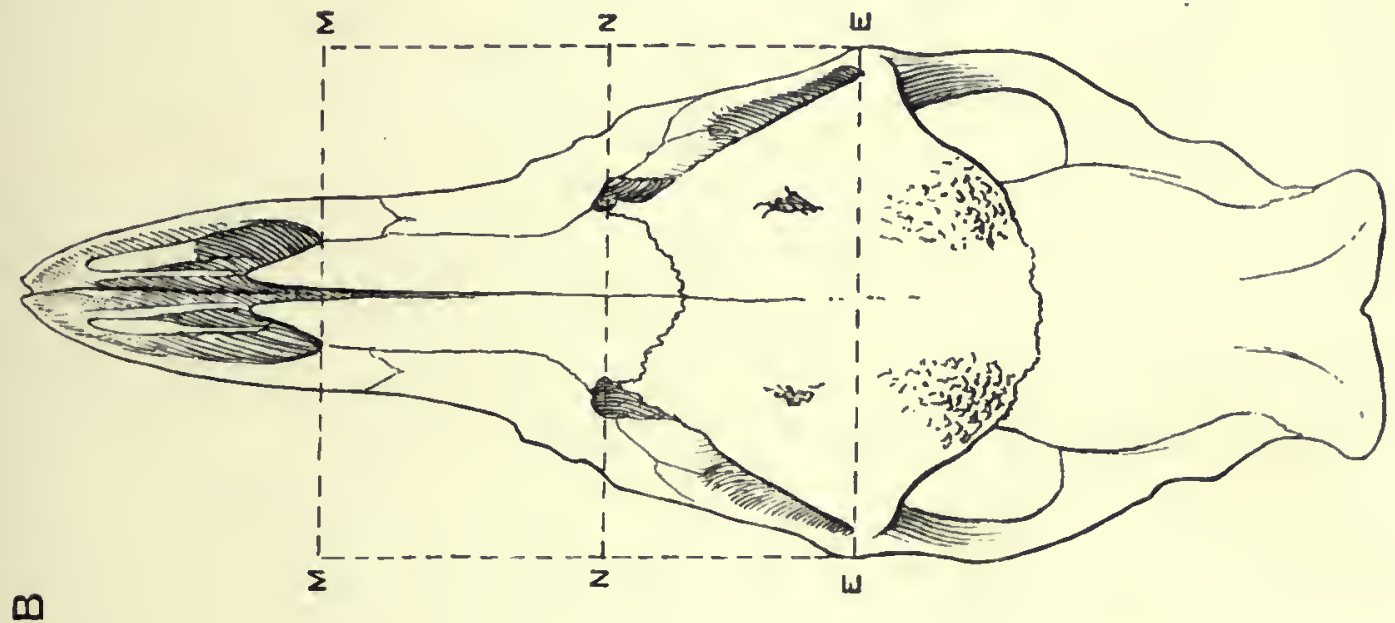

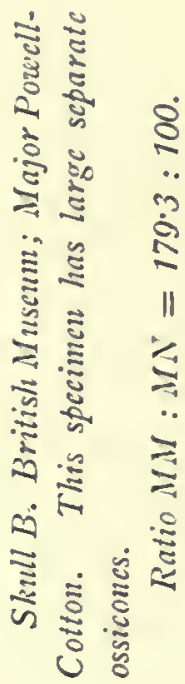
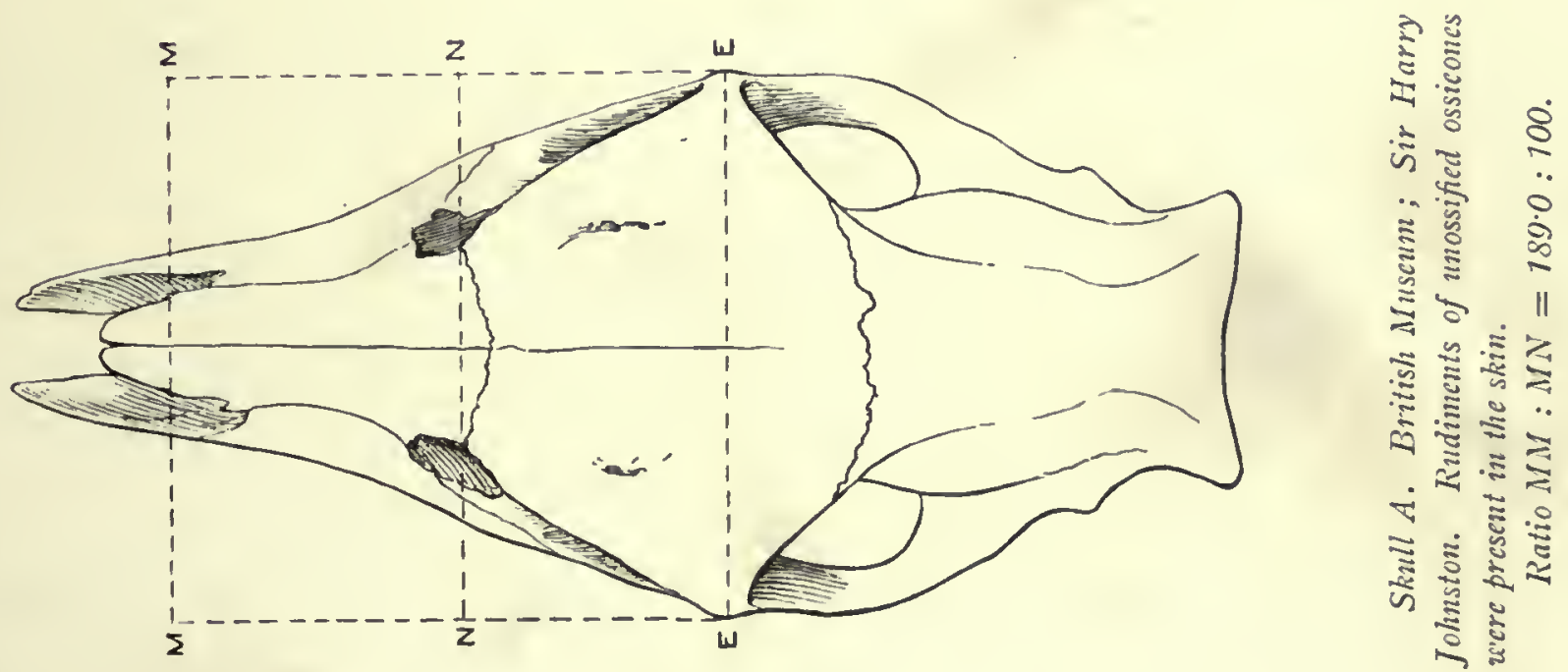

PLATE 14.

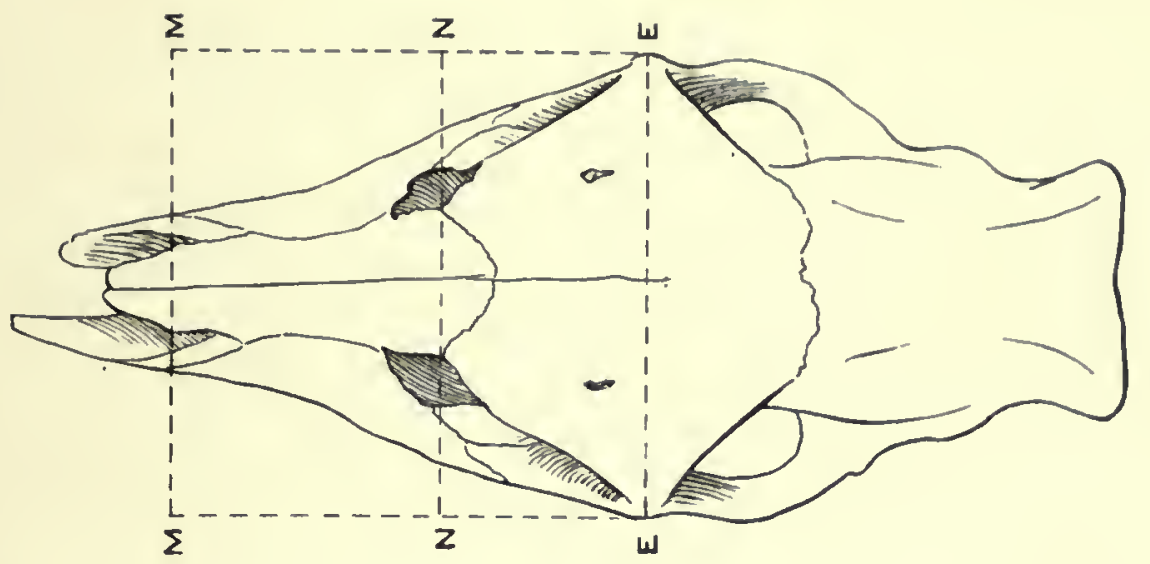

ᄂ
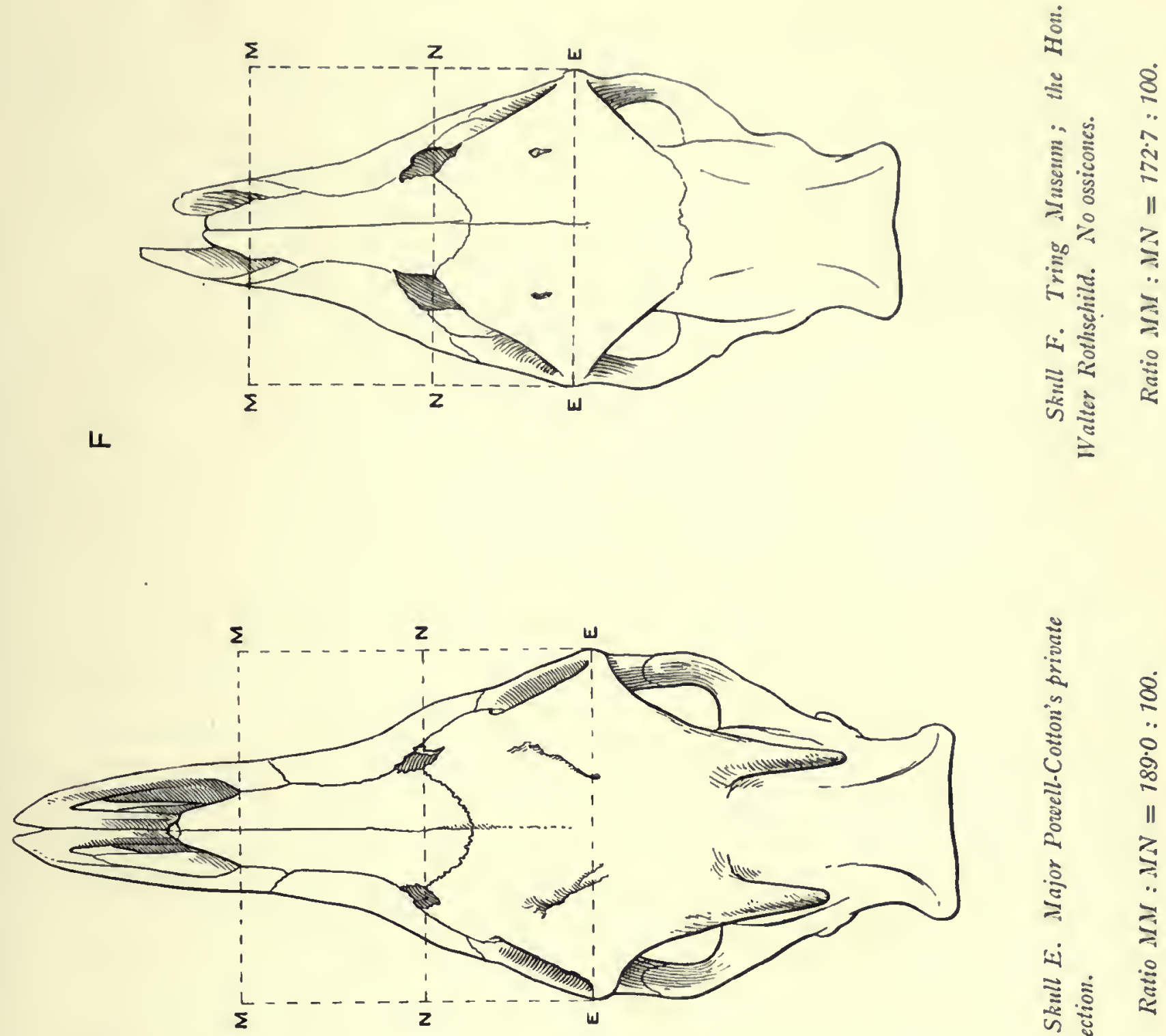

ш
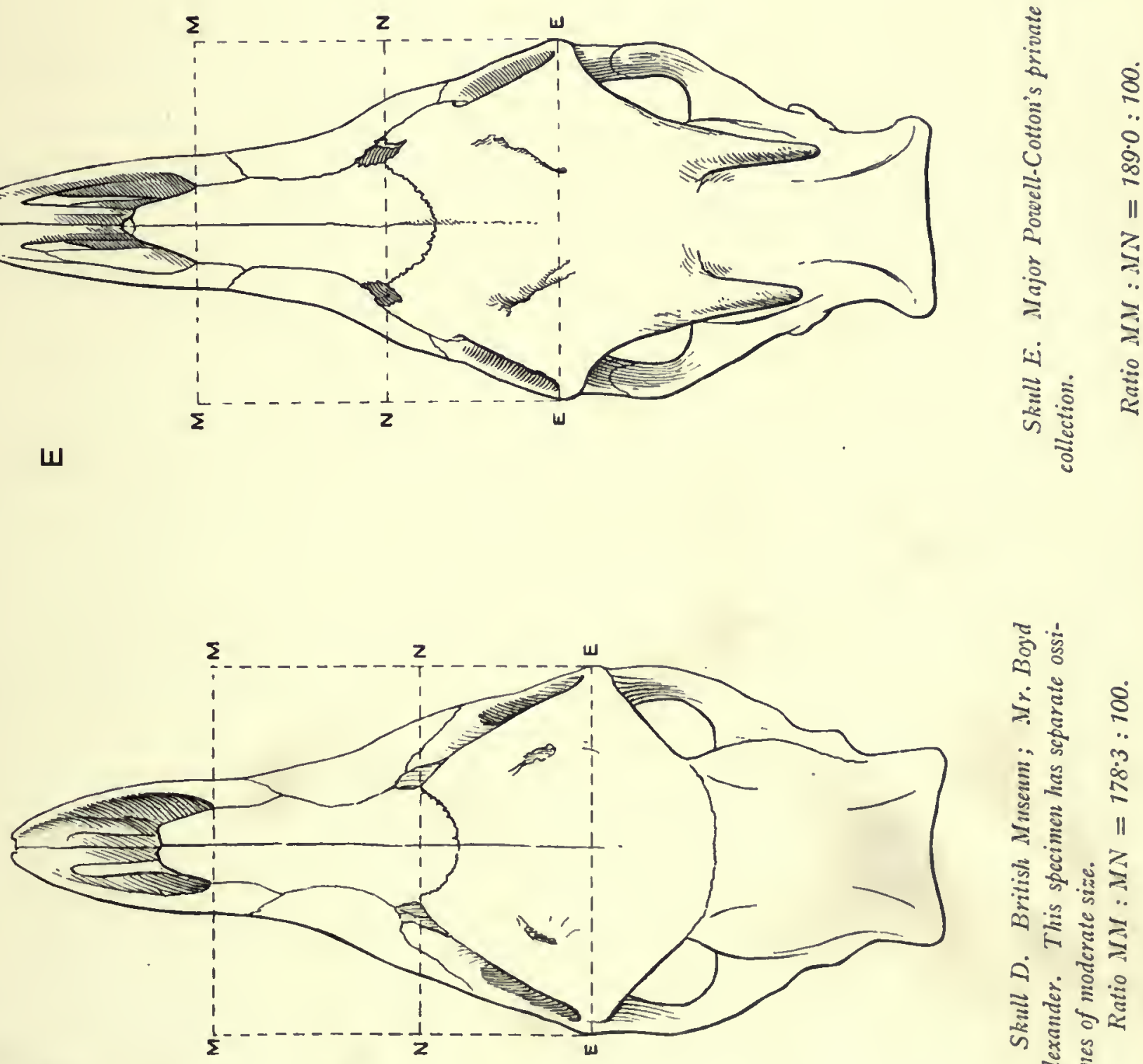

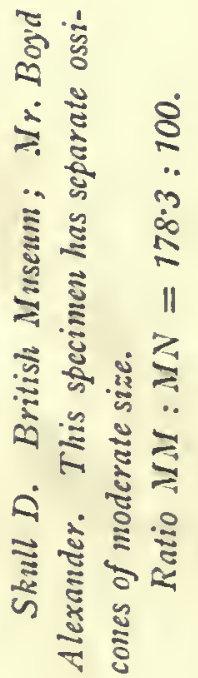



PLATE 15.
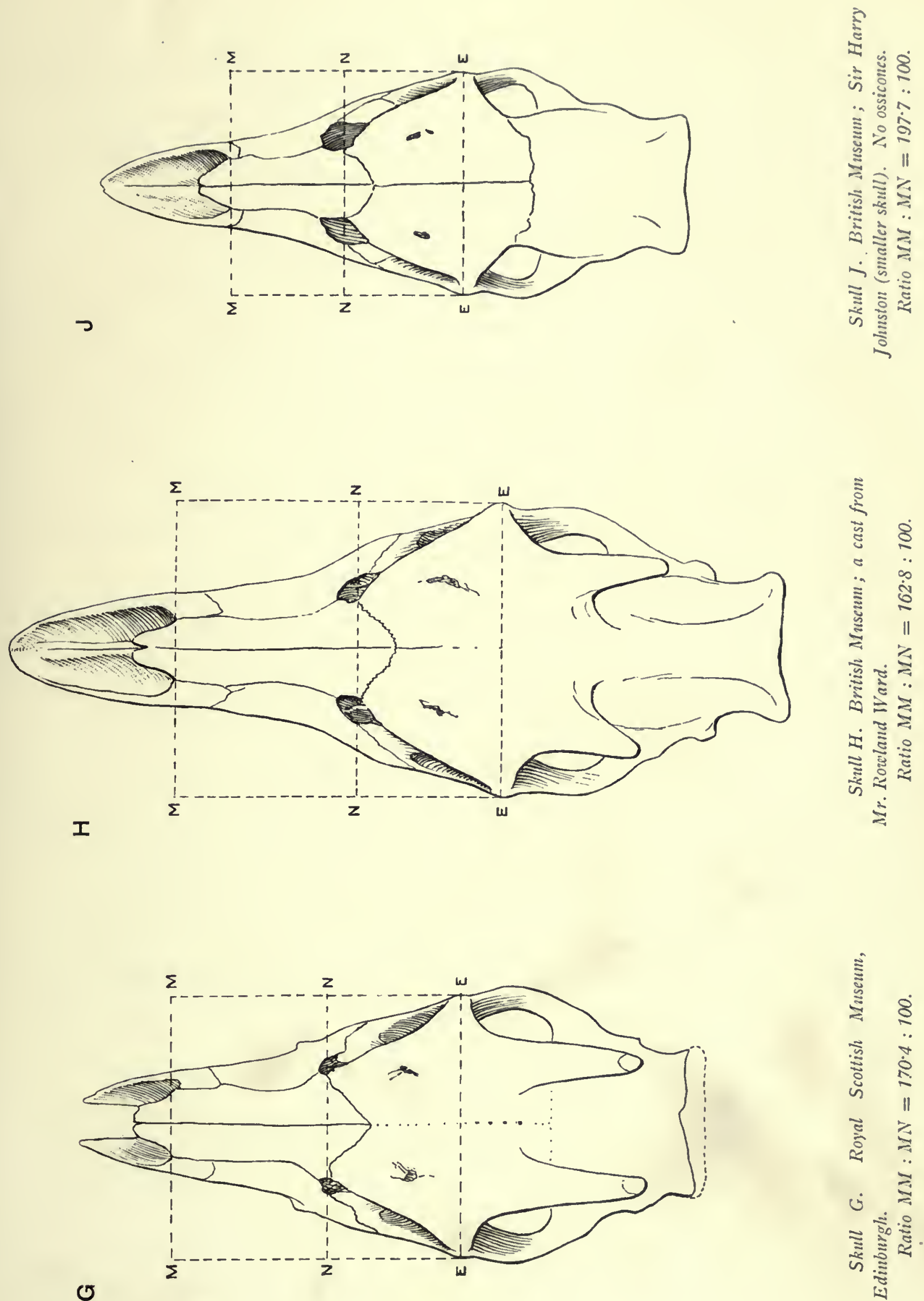

PLATE 16.

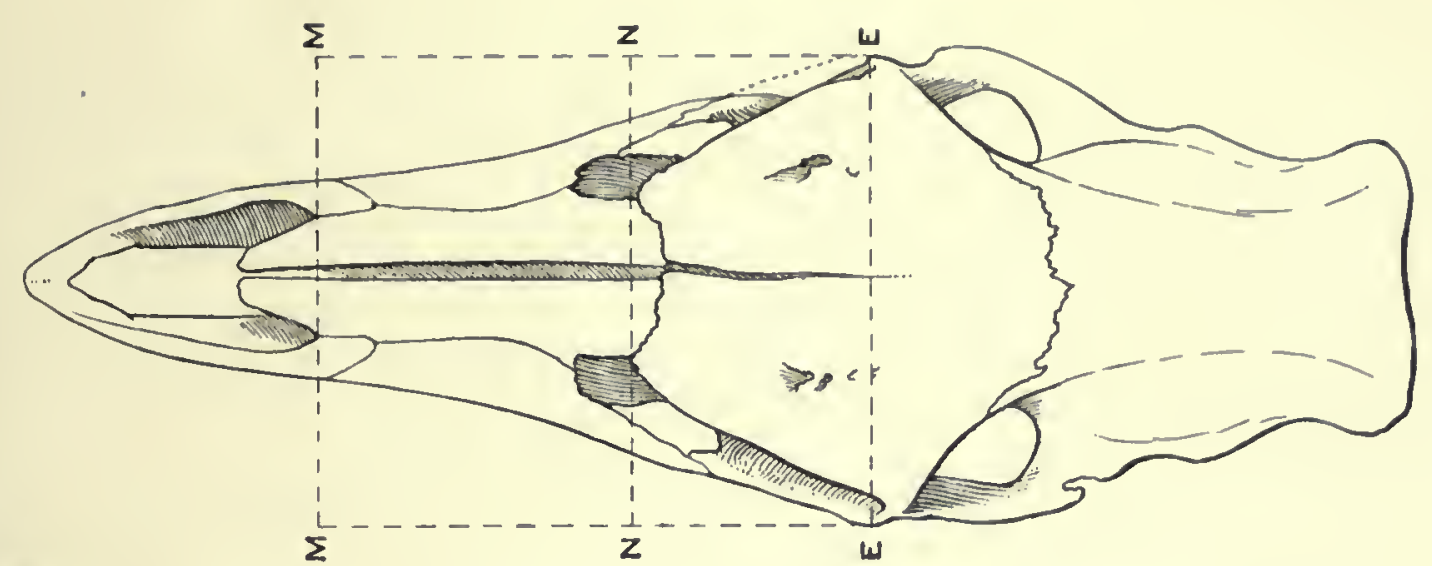

$\Sigma$
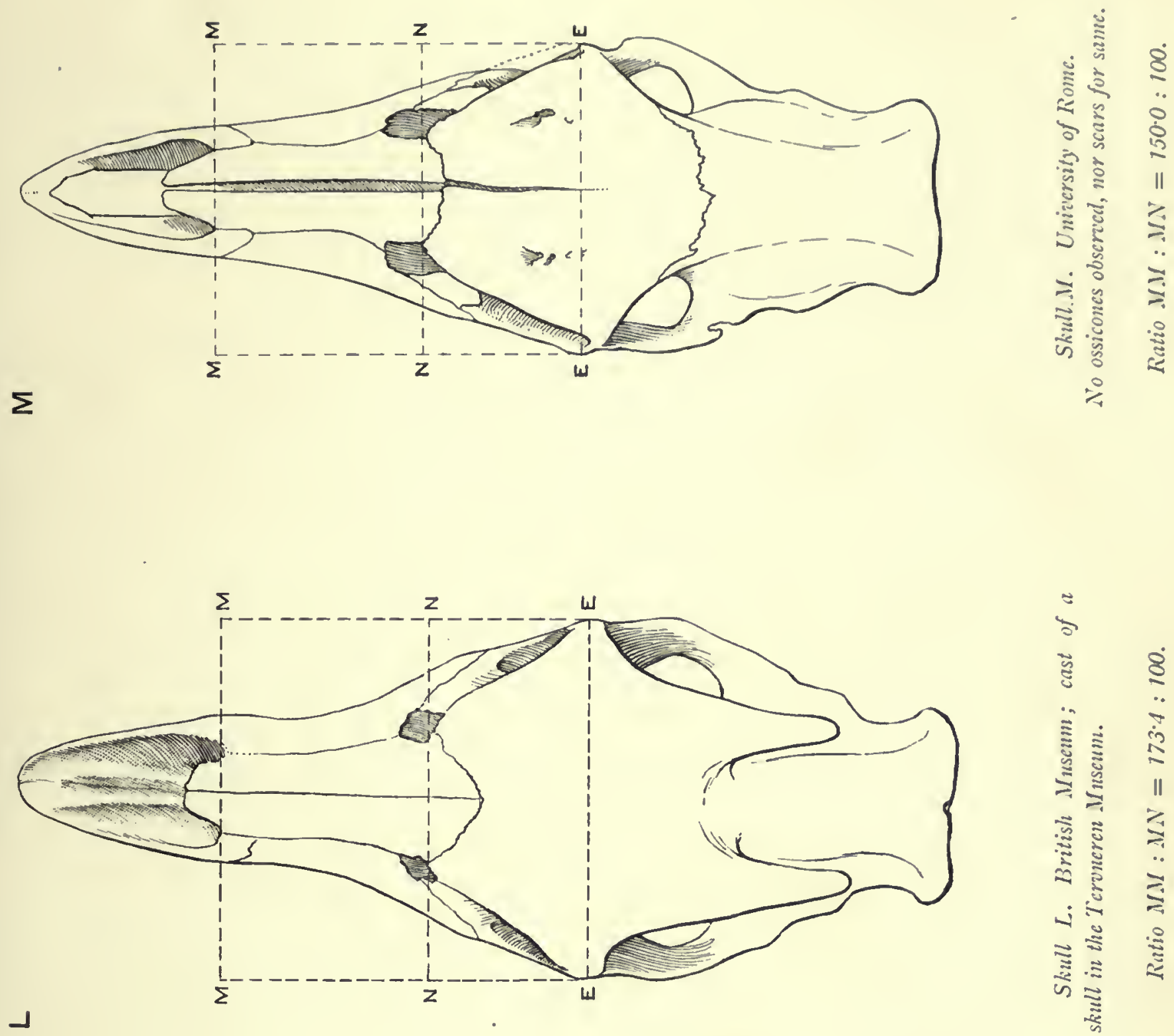

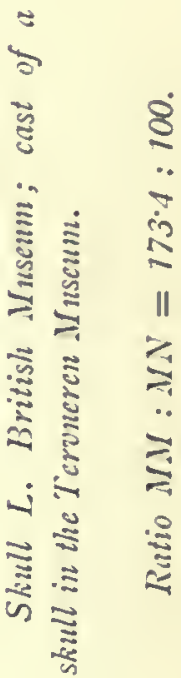
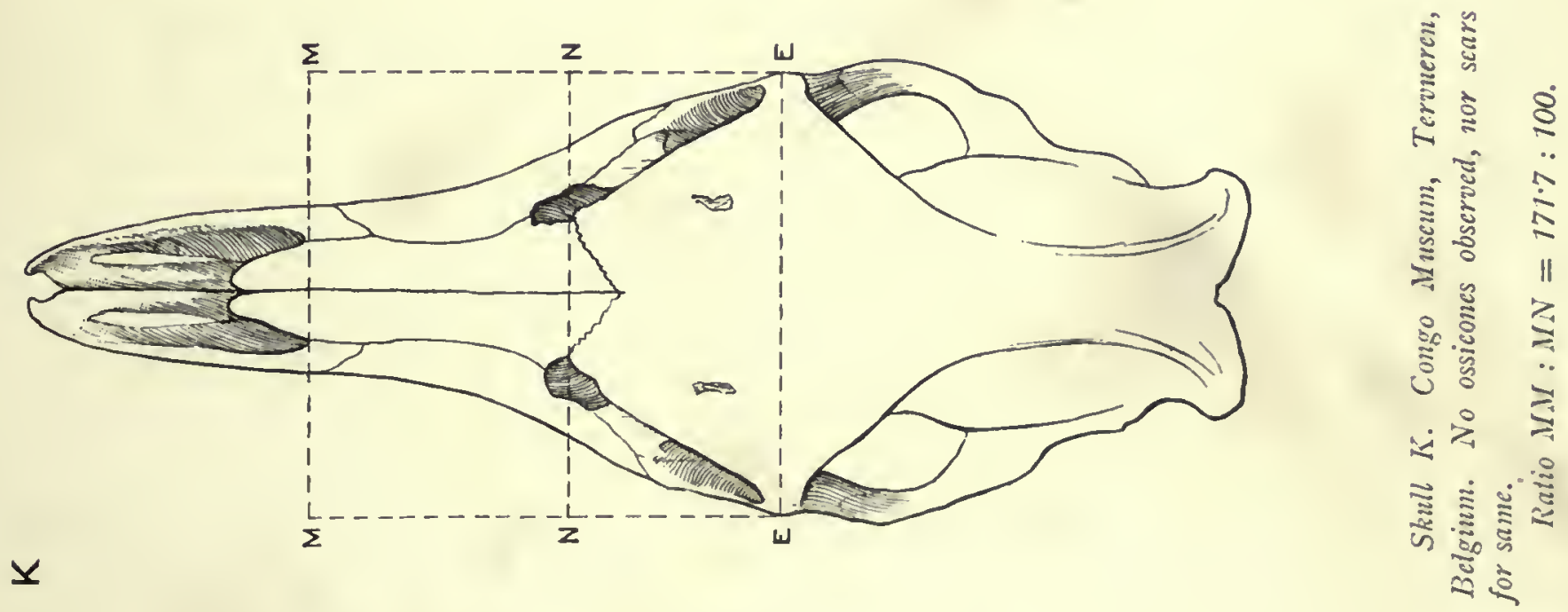

PLATE 17.

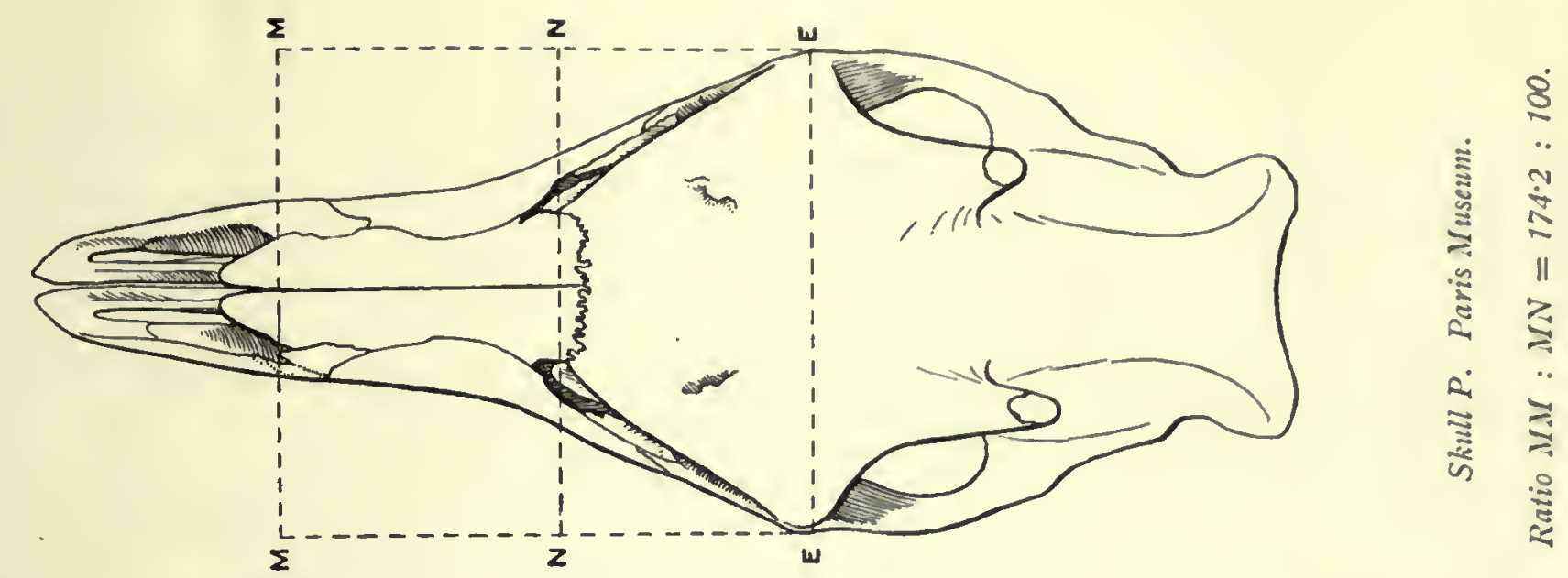

a.

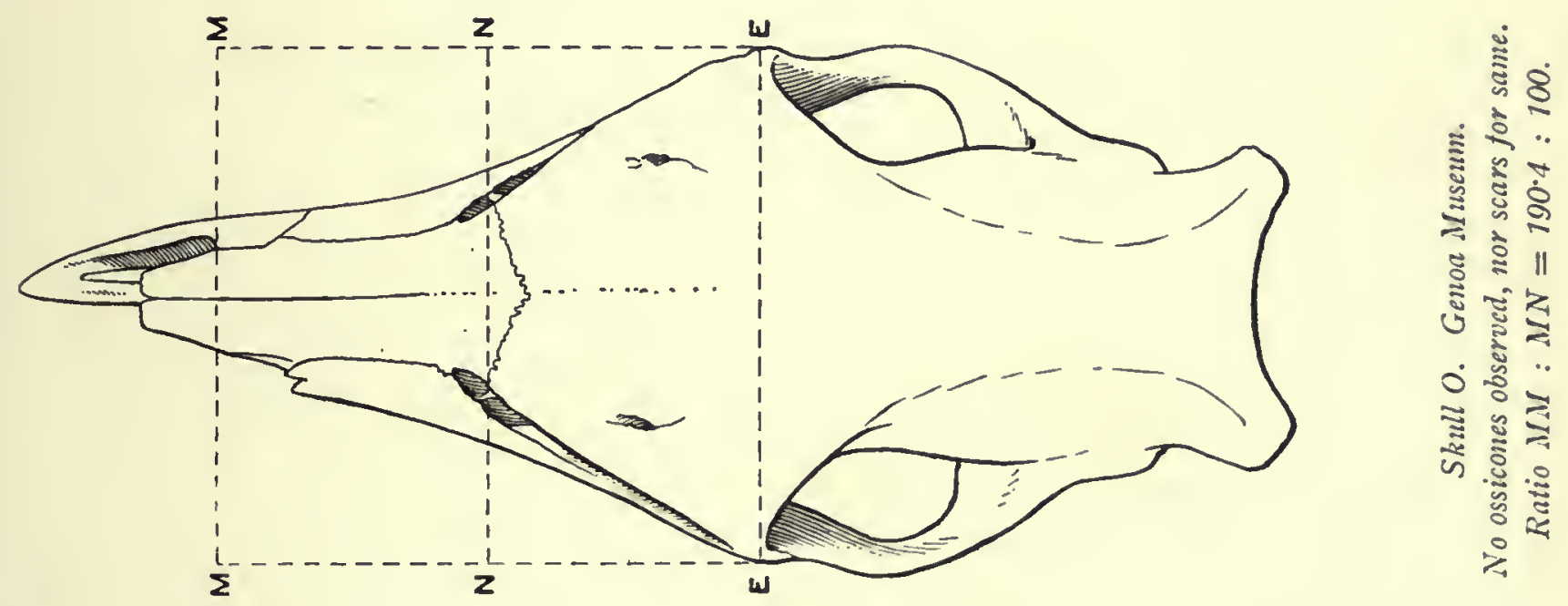

0

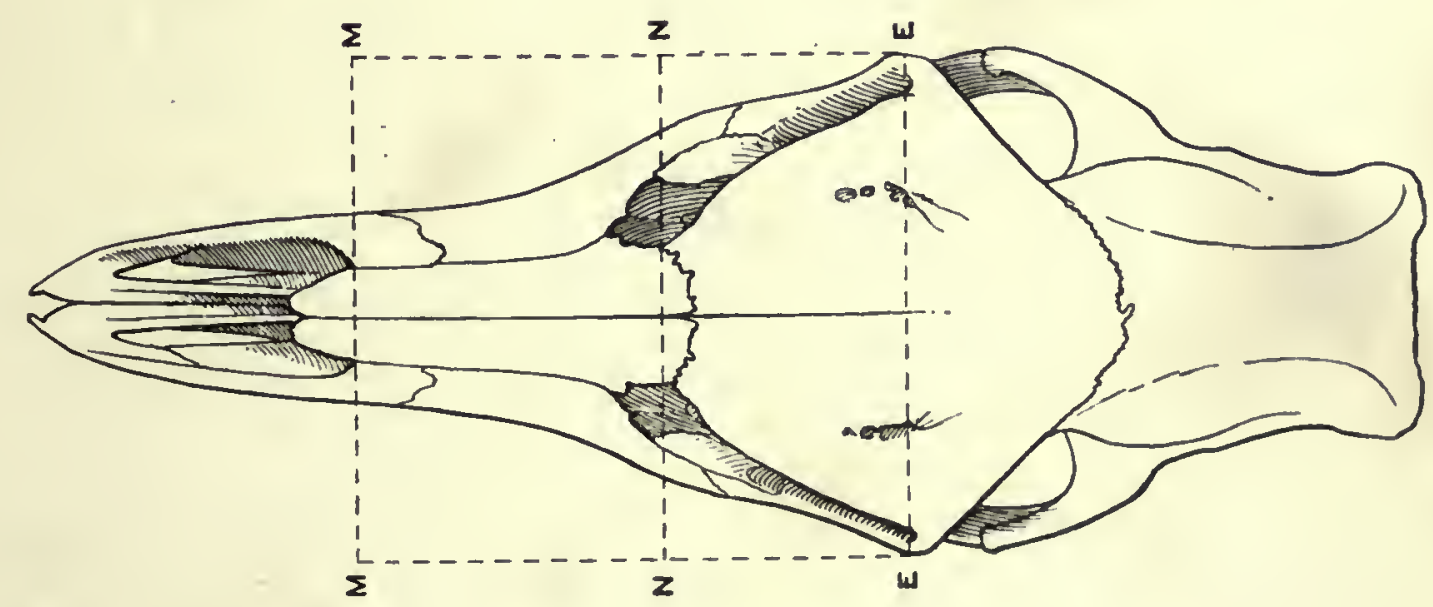

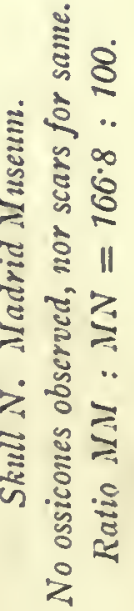

z 

PLATE 18.

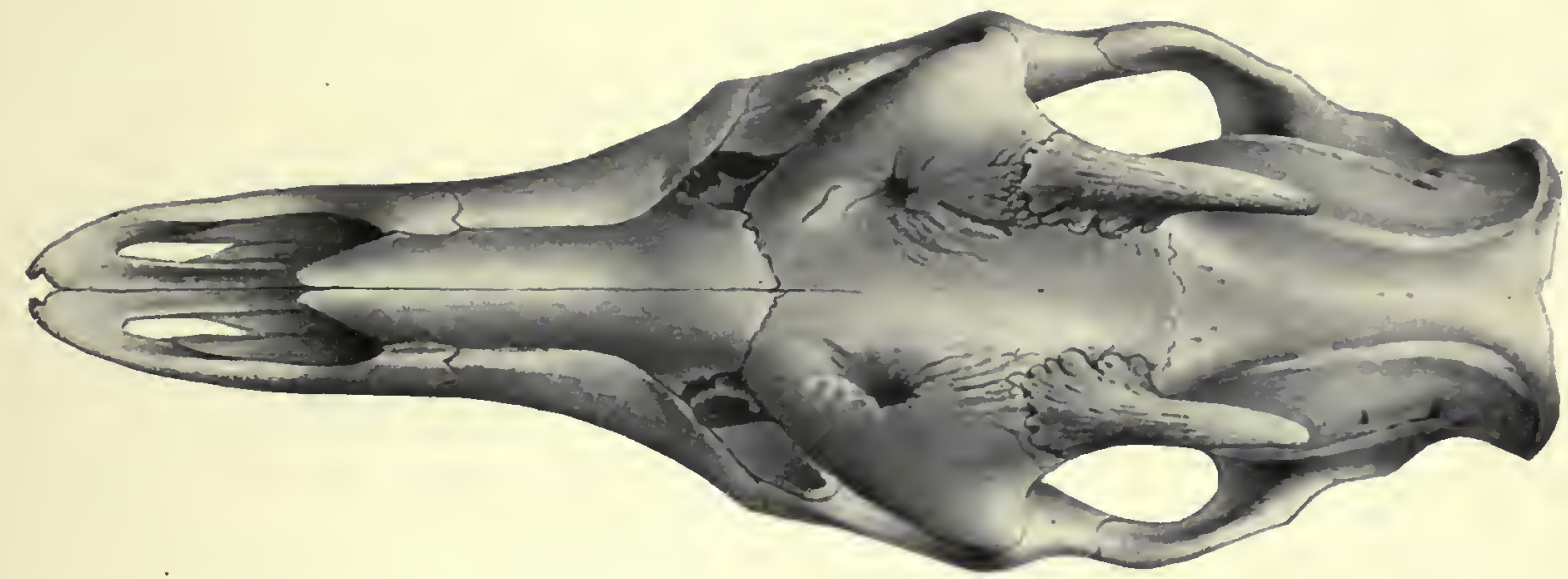

Fig. 1. Skull B; the skull of the skclcton purchased by the British Musetm of Major Powell-Cotton. Dorsal view, one-third natural size, with the ossicones in position. In Plate 3, fig. 2, the skull is draren with the ossicones removed.

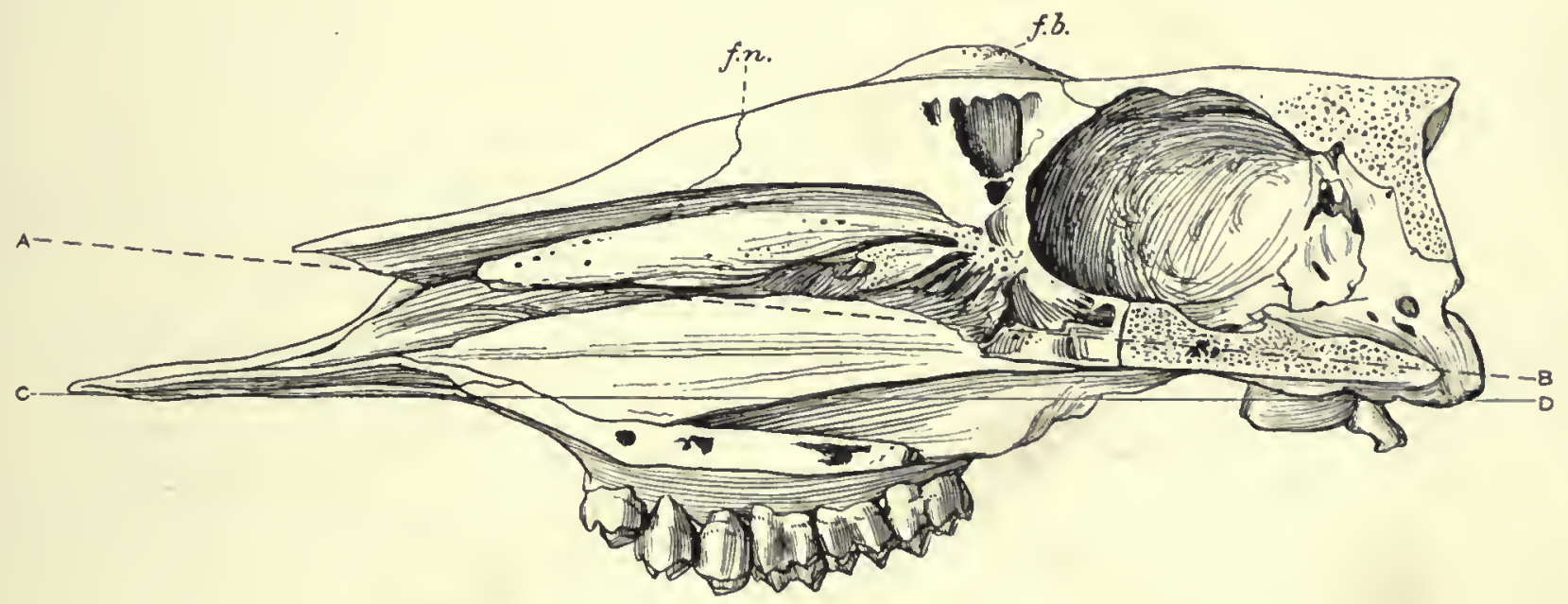

Fig. 2. Skull B; the skull of the skeleton purchased by the British Muscum of Major Powell-Cotton. Sagittal section, onc-third natural size.

f.b., frontal boss upon which the ossiconc fits; f.n., fronto-nasal suture; $A B$, a line dranen through the basicranial axis; $C D$, a line drawn along the palate, from the under side of the premaxilla to the under side of the back of the cranium. 


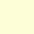


Explanation of PLATE 19. 


\section{PLATE 19.}

A series of diagrams showing the angles between the frontal, parietal, and supraoccipital bones, the basicranial axis, and the row of maxillary teeth in the Ox, Elk, Okapi, Elephant, and Man. The diagrams are based npon the inner view of the right half of sagittally bisected sknlls, and the thick lines are drawn straight from point to point, disregarding any curve of the bones that may occur between the points. The basicranial axis is set horizontally in each diagram.

A.-The middle of the front end of the presphenoid bone.

B.-The hind edge of the basioccipital bone.

FM.-The superior edge of the foramen magumm.

FP.-The sutmre between the frontal and parietal bones.

NF.-The suture between the masal and frontal bones.

PO.-The suture between the parietal and supraoceipital bones.

T'T.-The line of maxillary teeth.

The line $x y$ is drawn from the point PO parallel to the line 'I"T, and from the righthand end of the line I'T a perpendicular line ( 

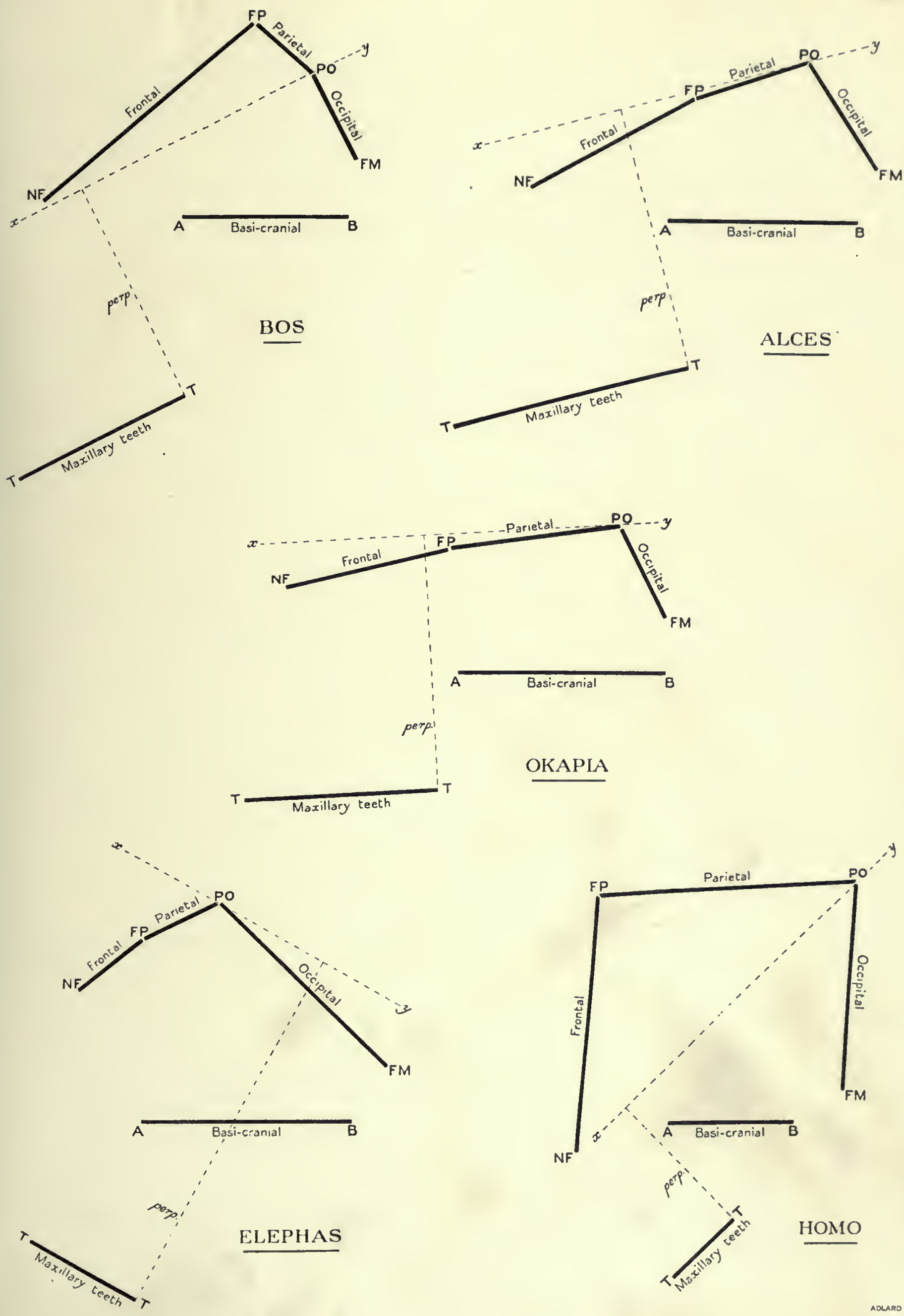

ADURO \& SON MPR. 

Explanation of PLATES 20-22. 


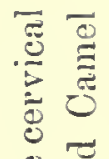 \\ 40 \\ $\stackrel{\overrightarrow{0}}{=}$ \\ 递}

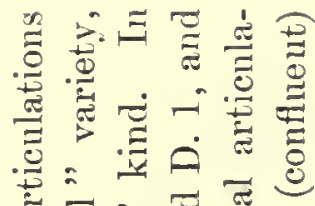

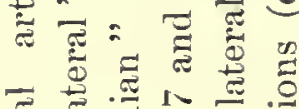

.

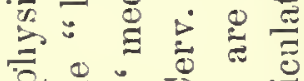

过

范:

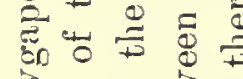

ㄴ.?

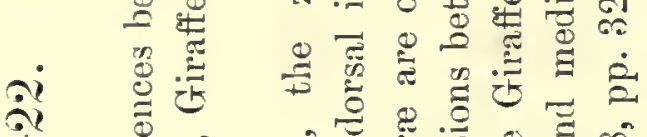

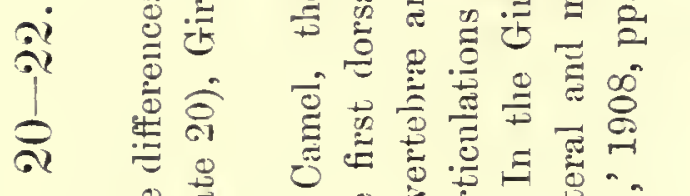

S

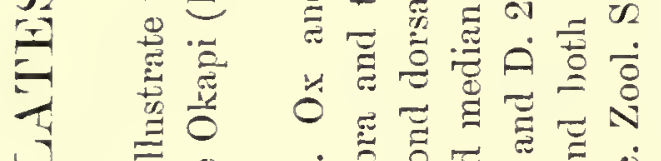

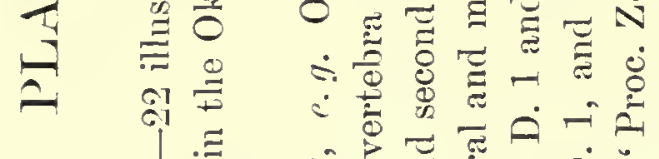

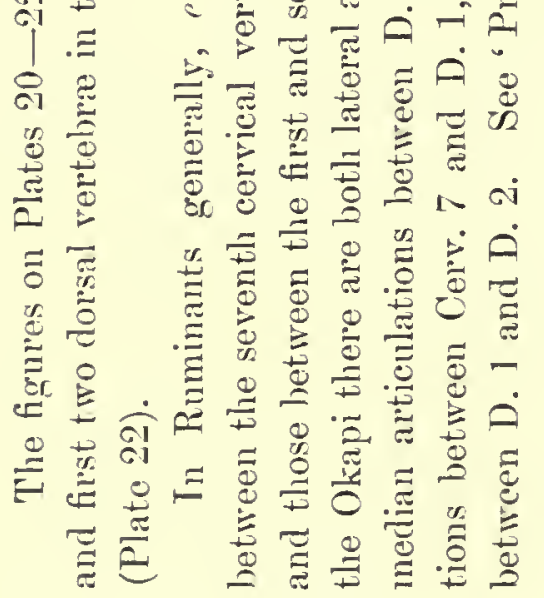

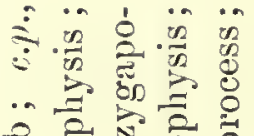

를

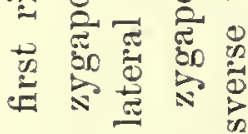

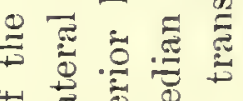

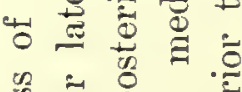

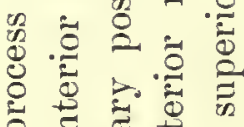

密

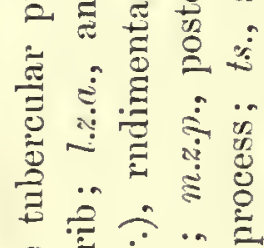

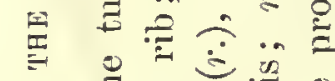

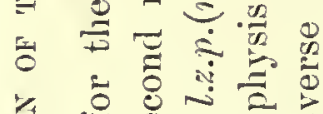

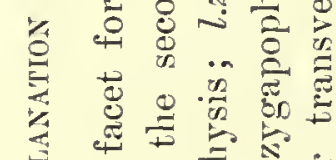

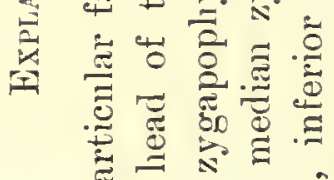

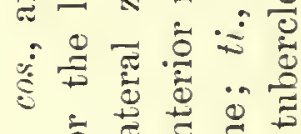

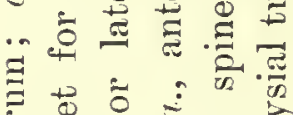

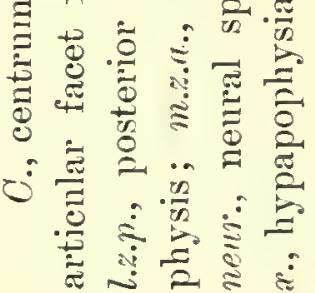



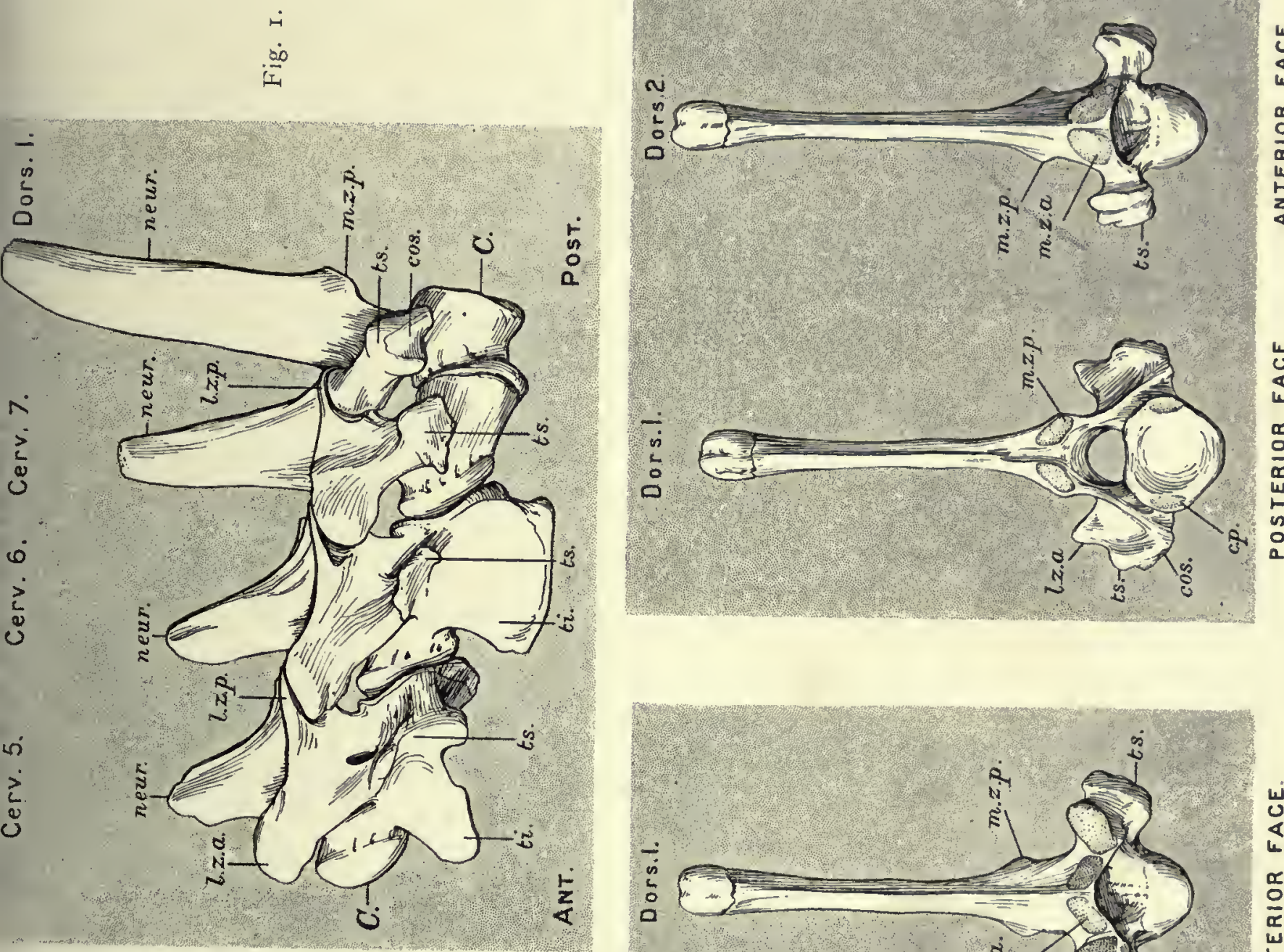

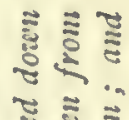

$\stackrel{\circ}{\circ}$

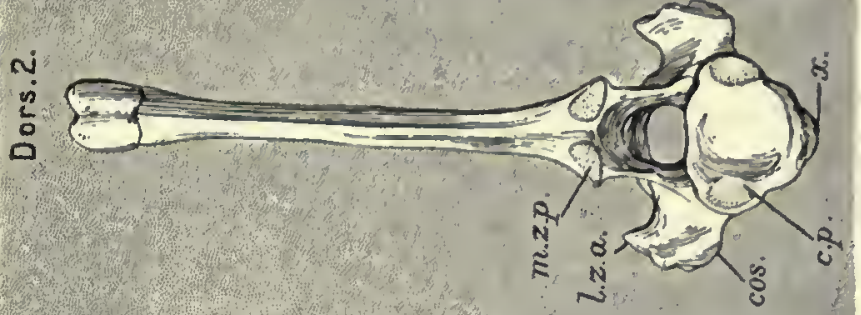

《

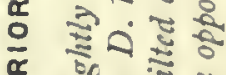

品 $\approx$

is bo है ह

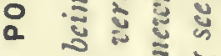

व

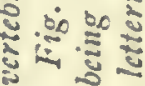

แ்

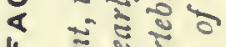

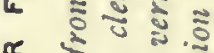

$\frac{0}{\pi} \leftleftarrows$

แ

य

馬

-

a

ن

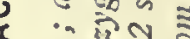

- छัะ

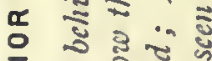

ฐ๐.

온잉

ะ

450.0

记证

ว

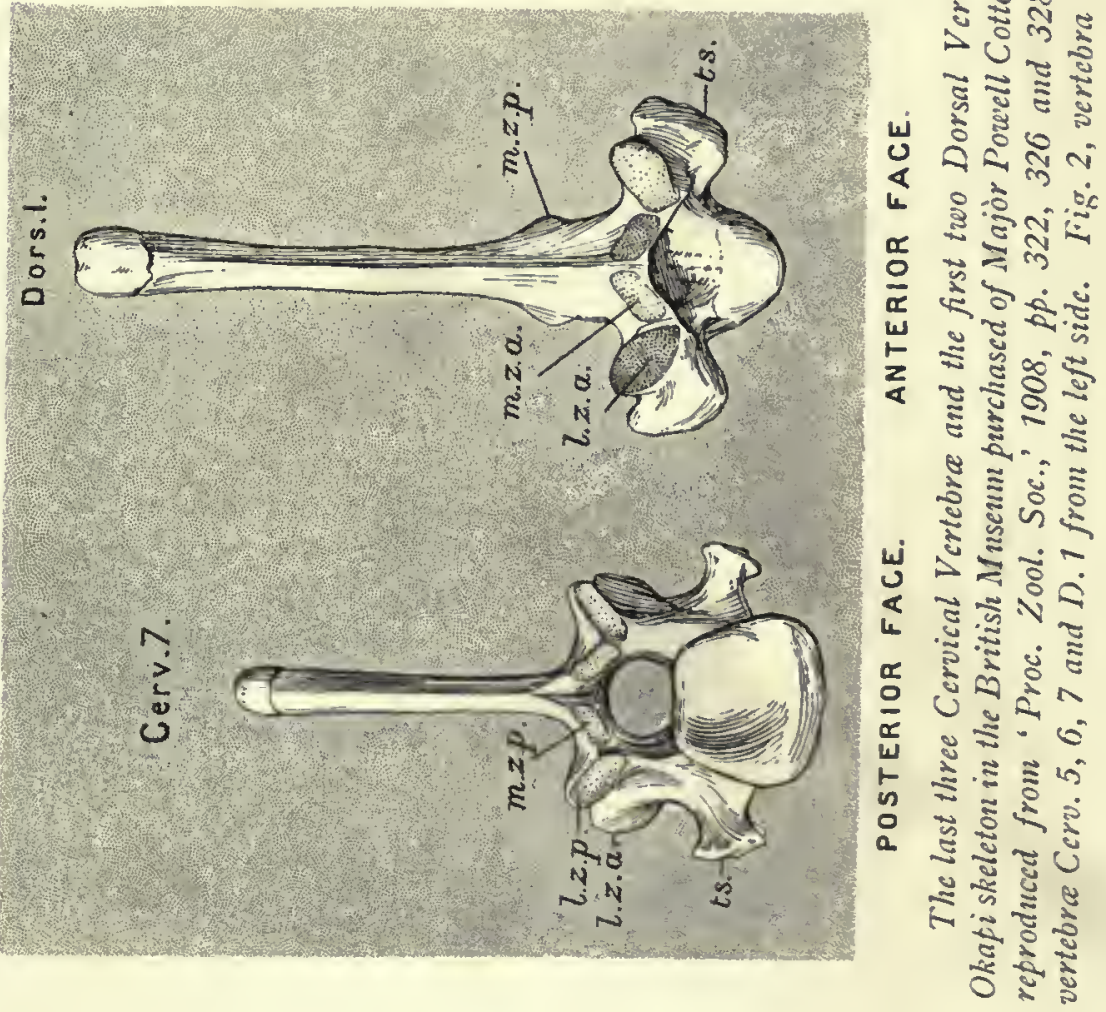

ज行

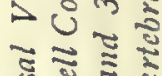

น

\& $a \leq \pi i$

$4 \quad 3: 0$

$x$ 돈

मे

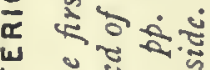

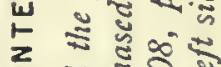

$<\cong$

ह

今ิ

迩饮

แ่

$\frac{1}{0}$
$\frac{1}{0}$ 

PLATE 2I.

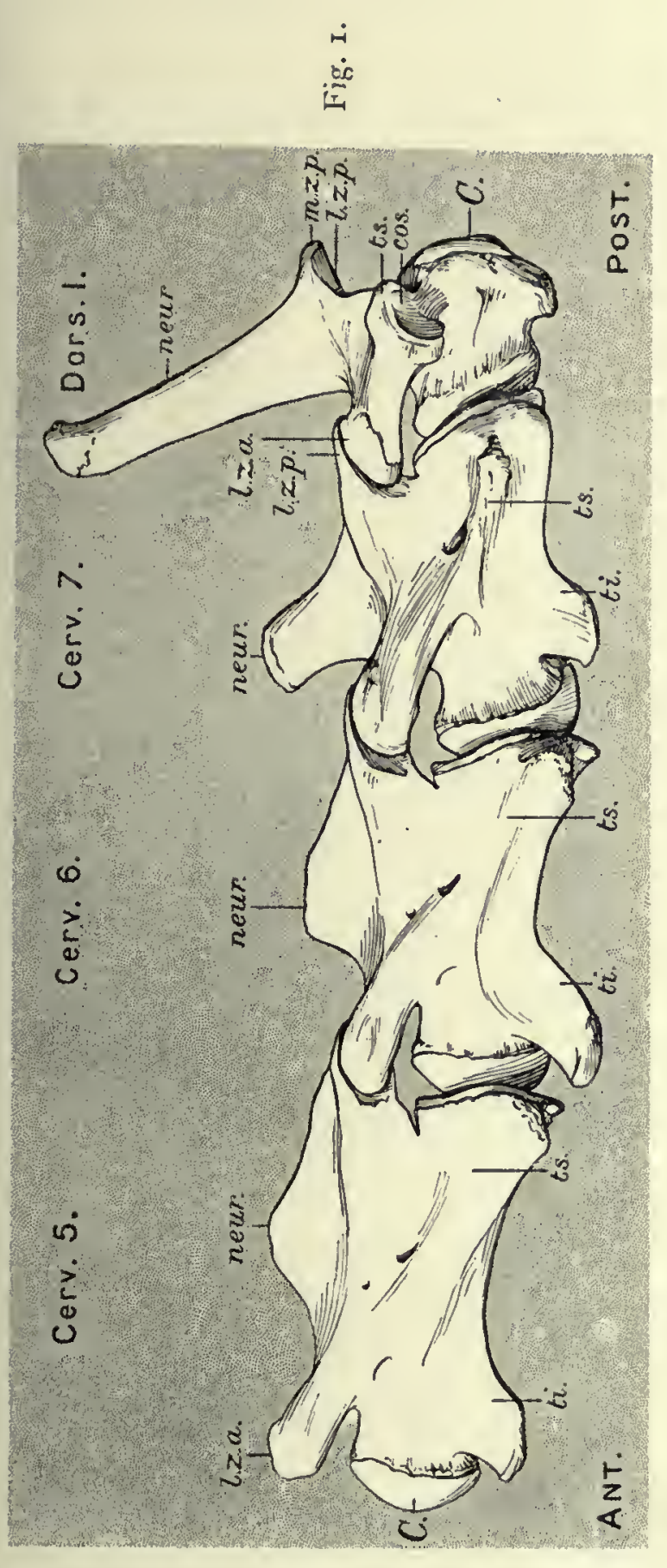

$\frac{u}{\frac{u}{u}}$ $\dot{m}$
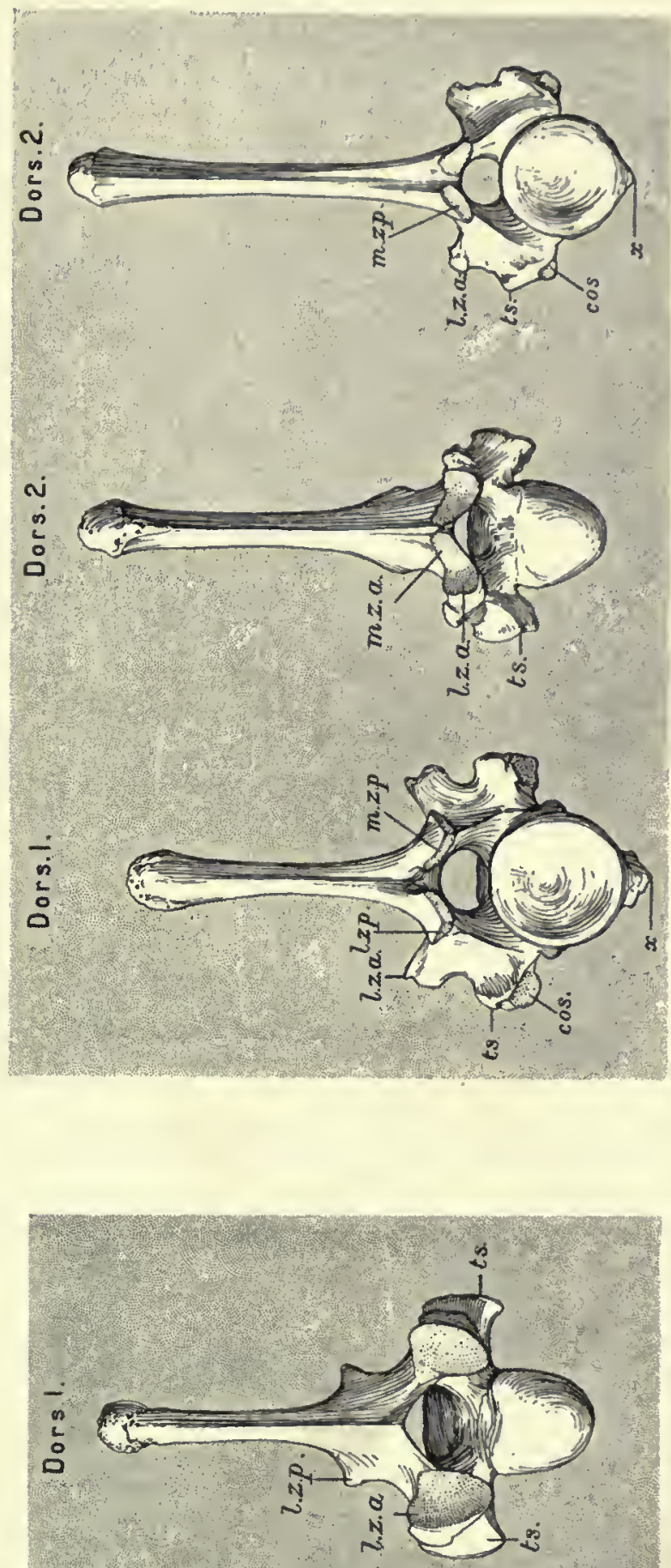

$\underset{\dot{c}}{\dot{i}}$

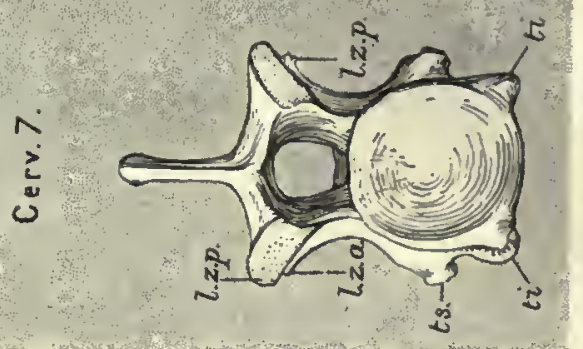

:

สิ ป ะ

है

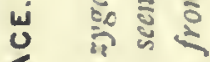

ะ

เ

采 के छ

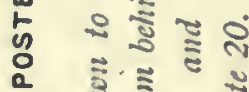

० उ

ن

㟧

-

\&

ส

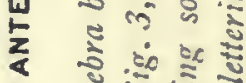

竎证产

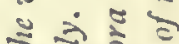

공

嵌

ए

)

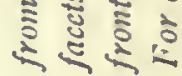
:

$\cong \dot{5} \Xi$ कर $y=0^{\circ}$ ำ

$د$ ะ

च

के ะ

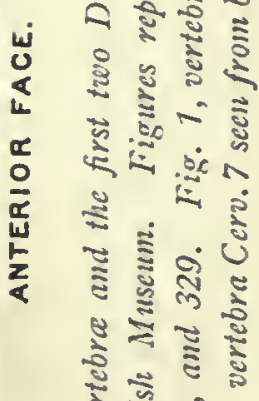

고ำ

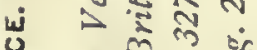

ष है -

กั้ ส त

ํ.

ํํำ

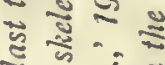

¿ ปัฐ 


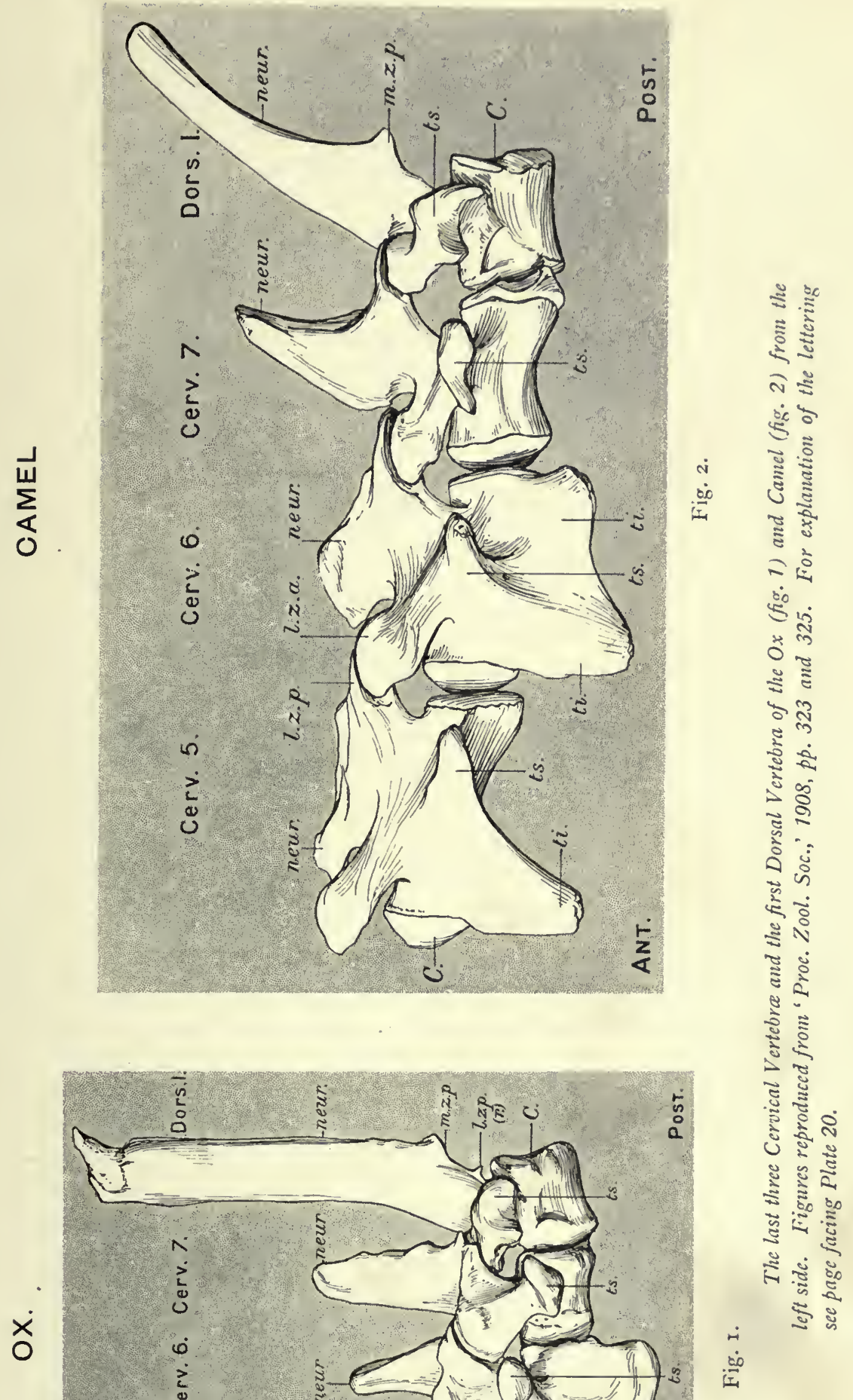

Explanation of PLATES 23-28. 


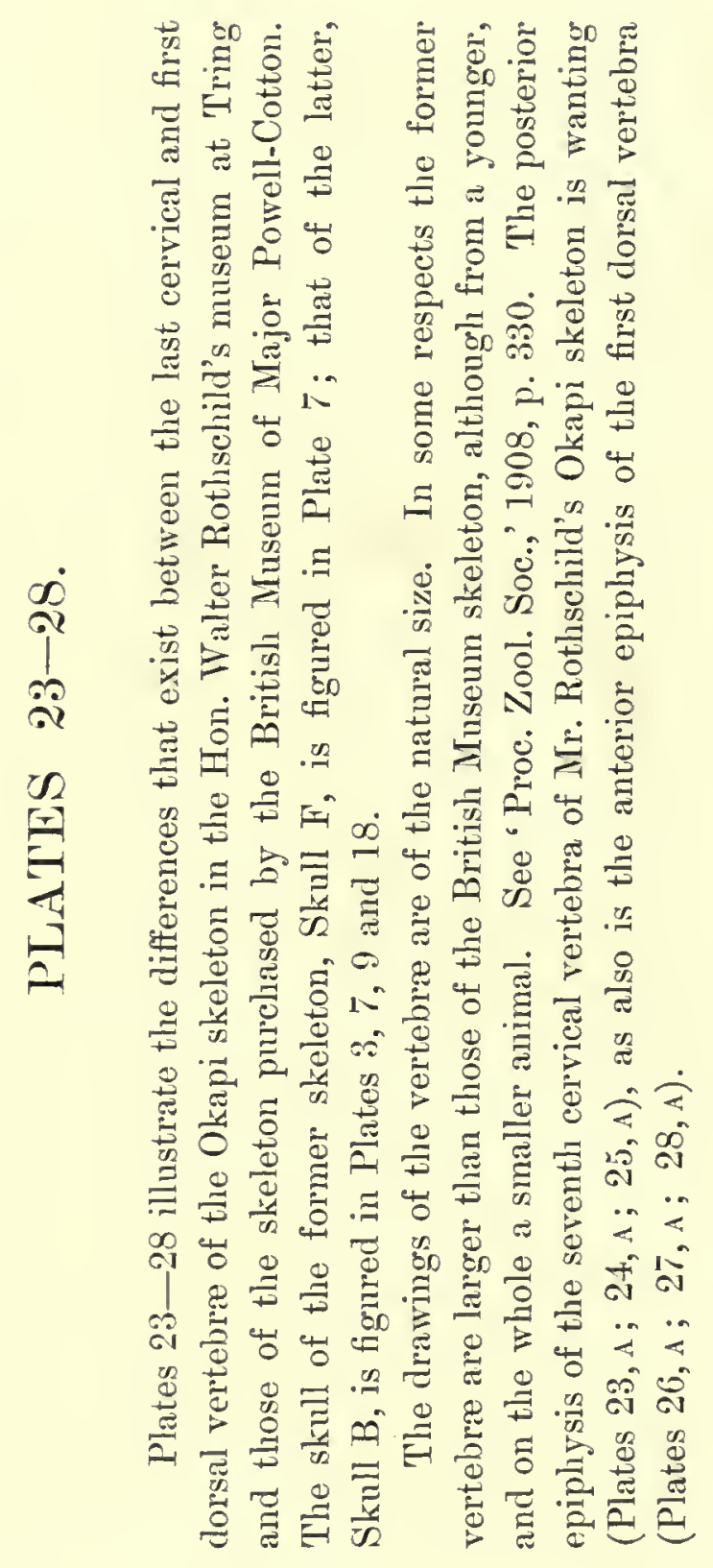



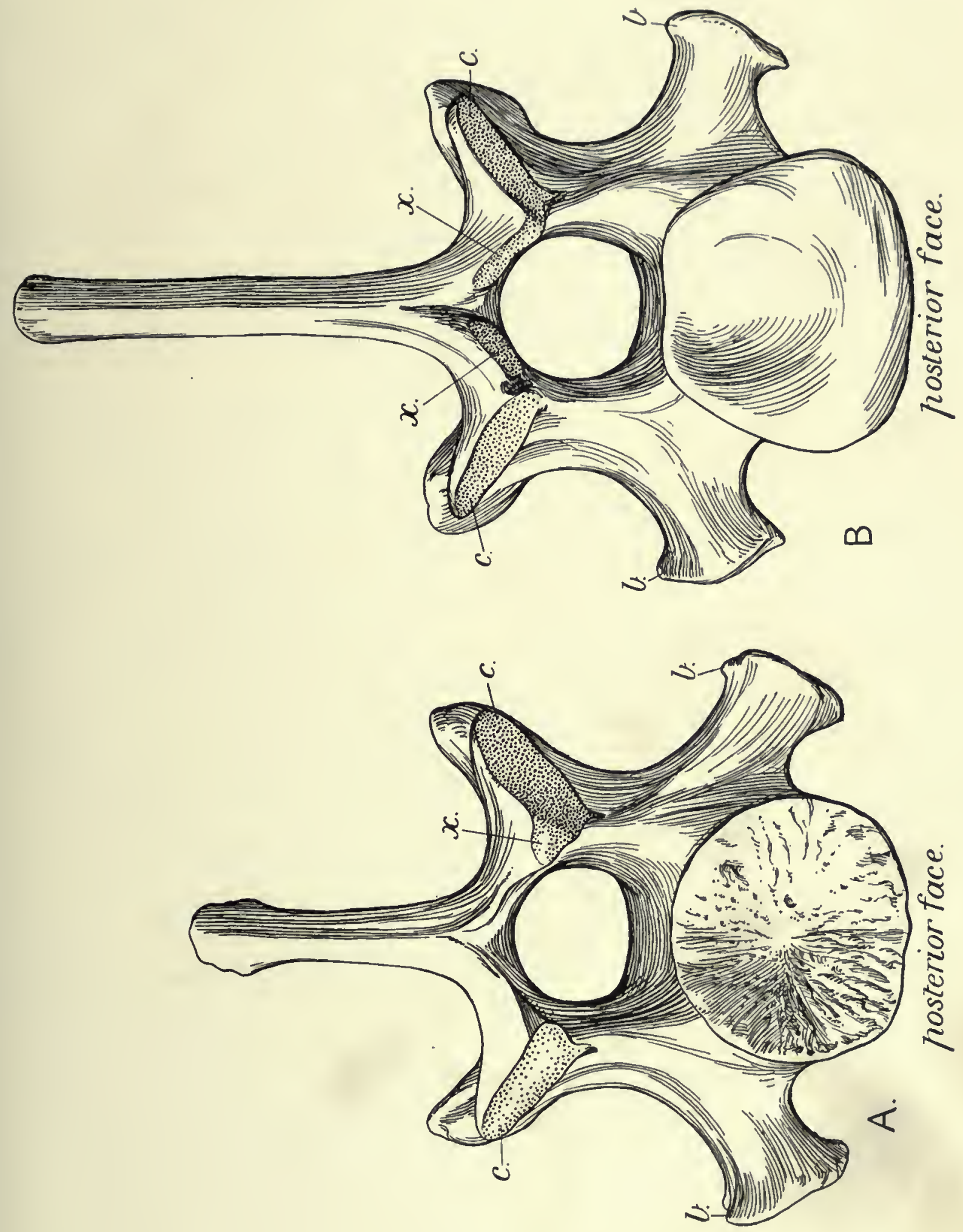

PLATE 24.

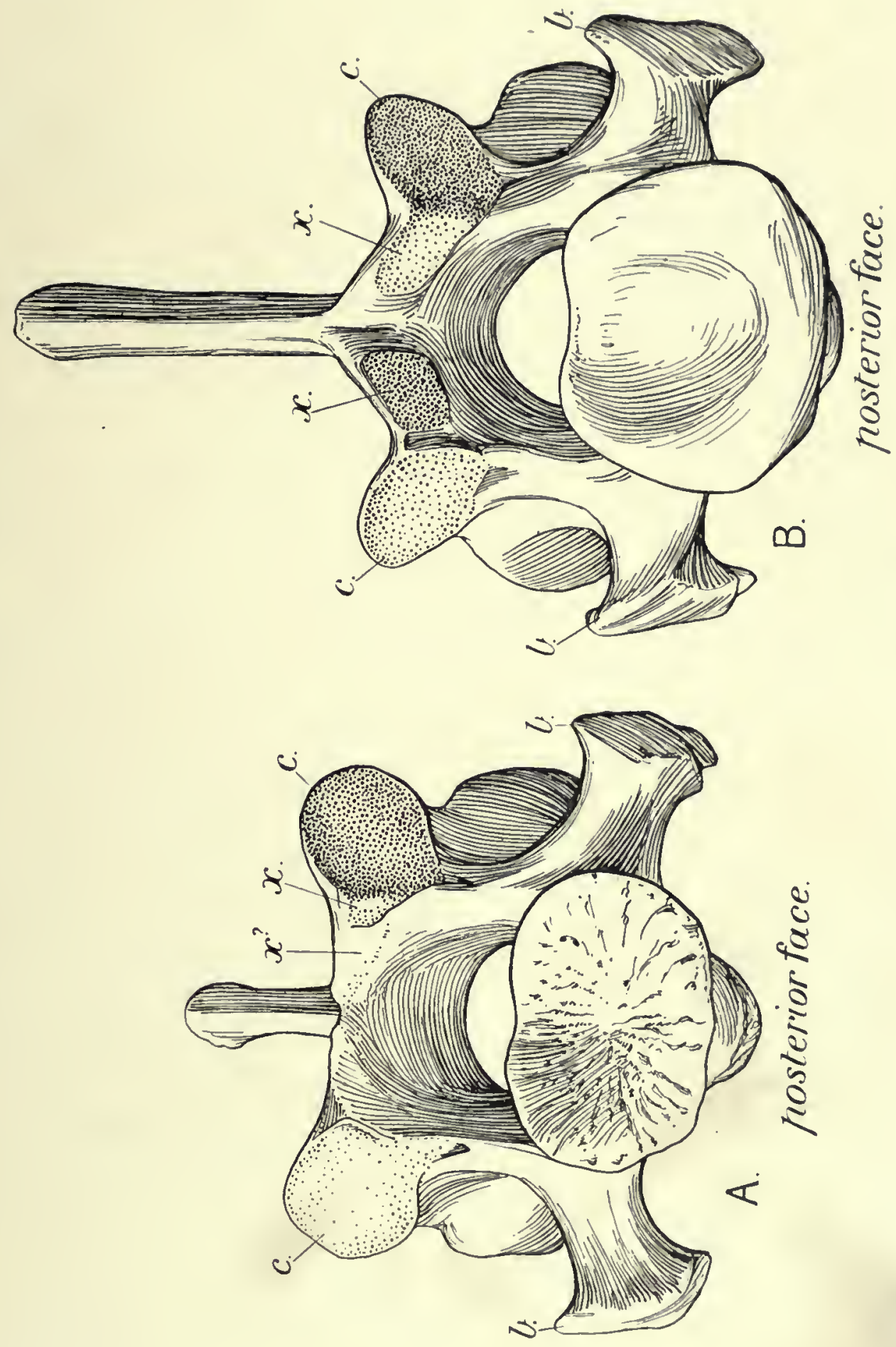

 

PLATE 25.

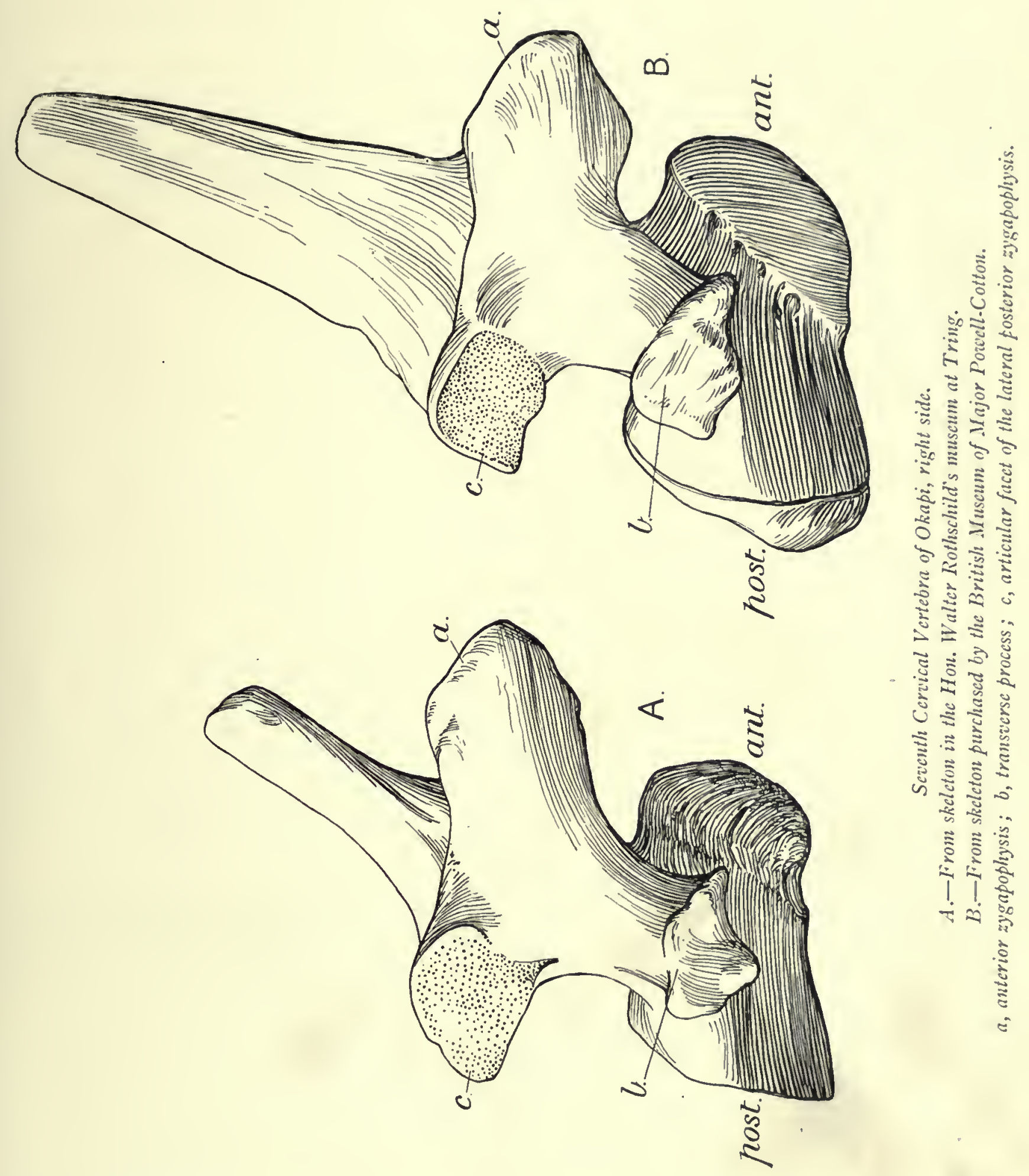




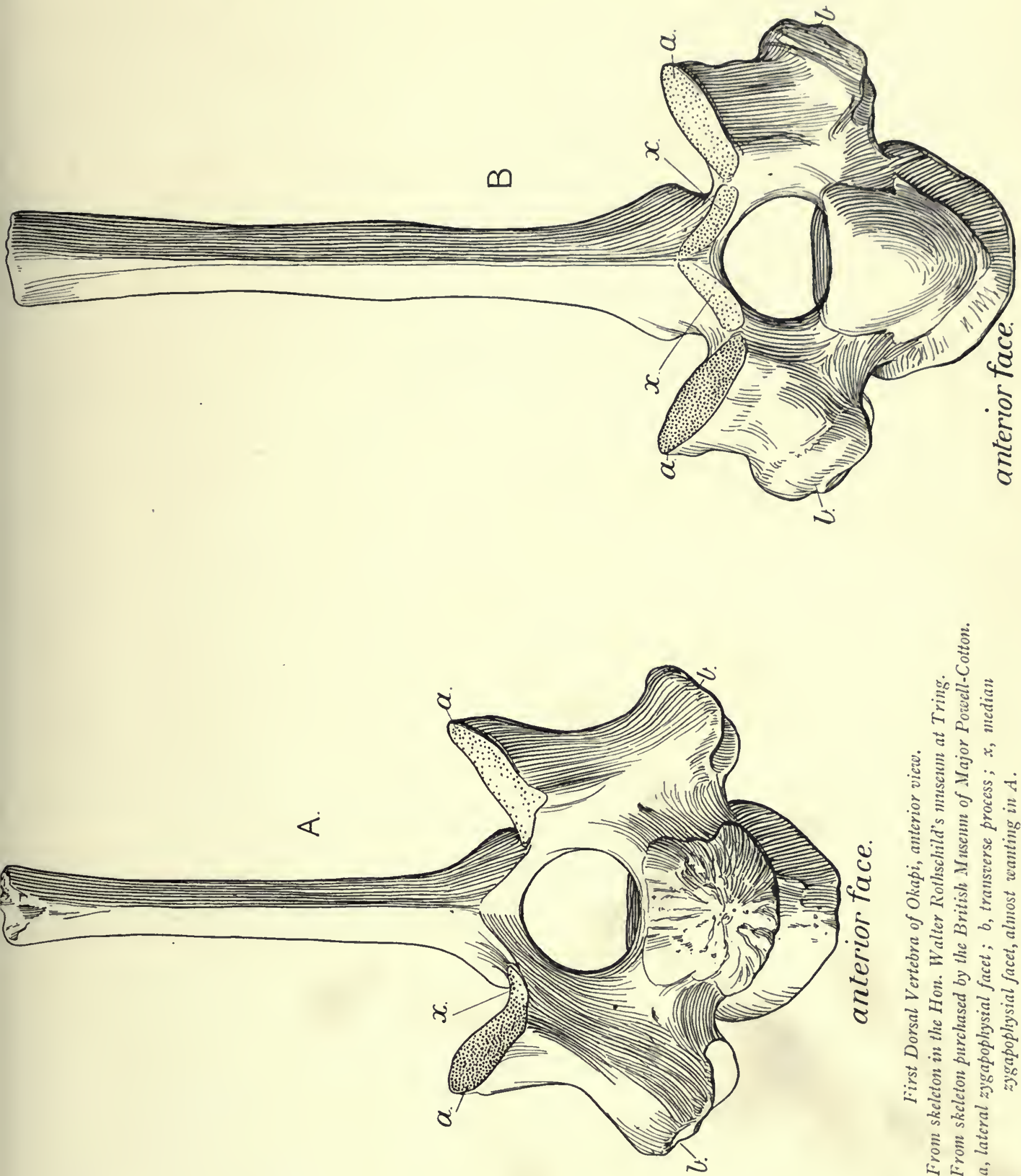


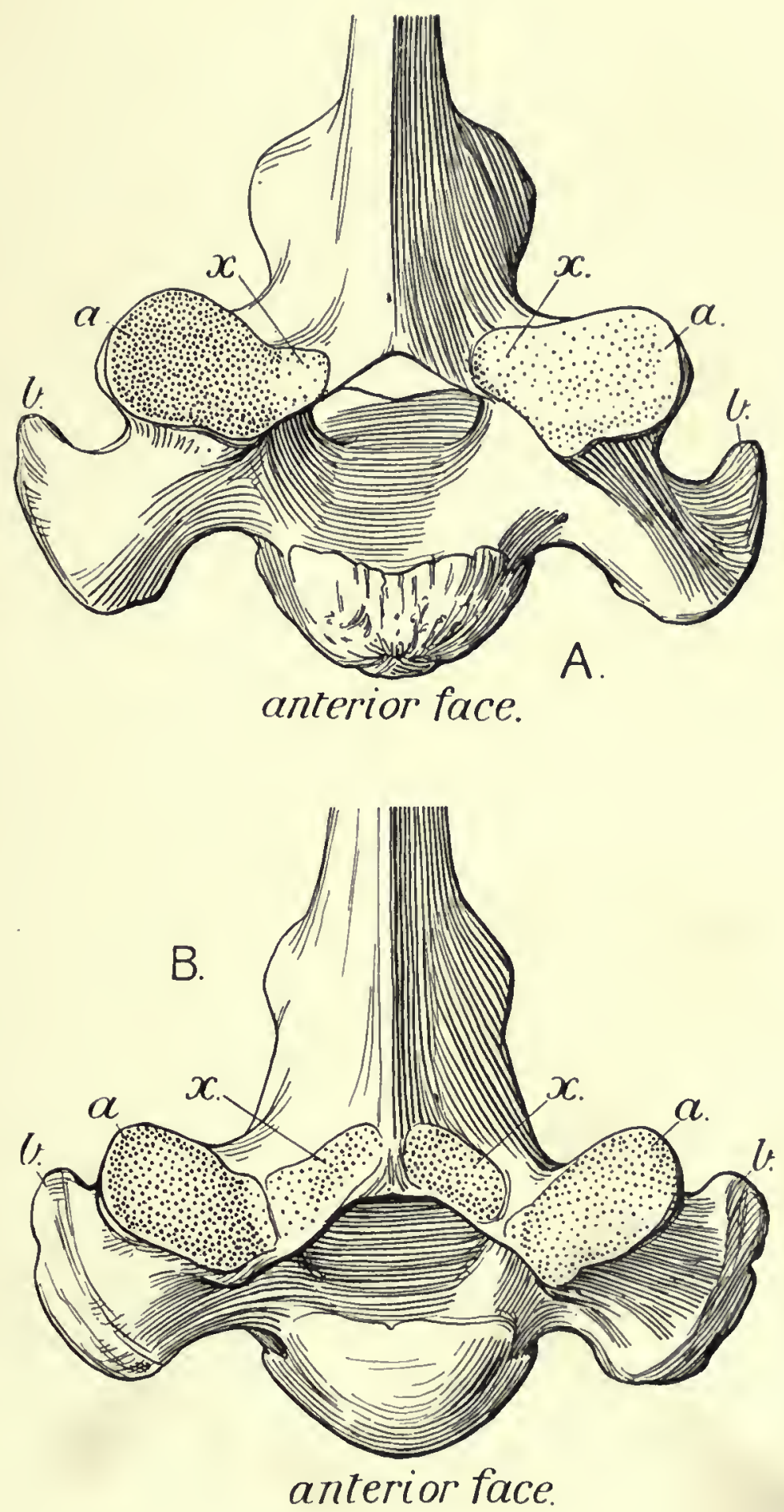

First Dorsal Vertebra of Okapi, slightly tilted dow'n so as to show more clearly the zygapoplysial facets, anterior view.

A.-From skelcton in the Hon. Walter Rothschild's museum at Tring.

B.-From skeleton purchased by the British Museum of Major Powell-Cotton.

$a$, lateral zygapopliysial facet; $b$, transverse process; $x$, median zvgrapophysial facet, almost wanting in $A$. 


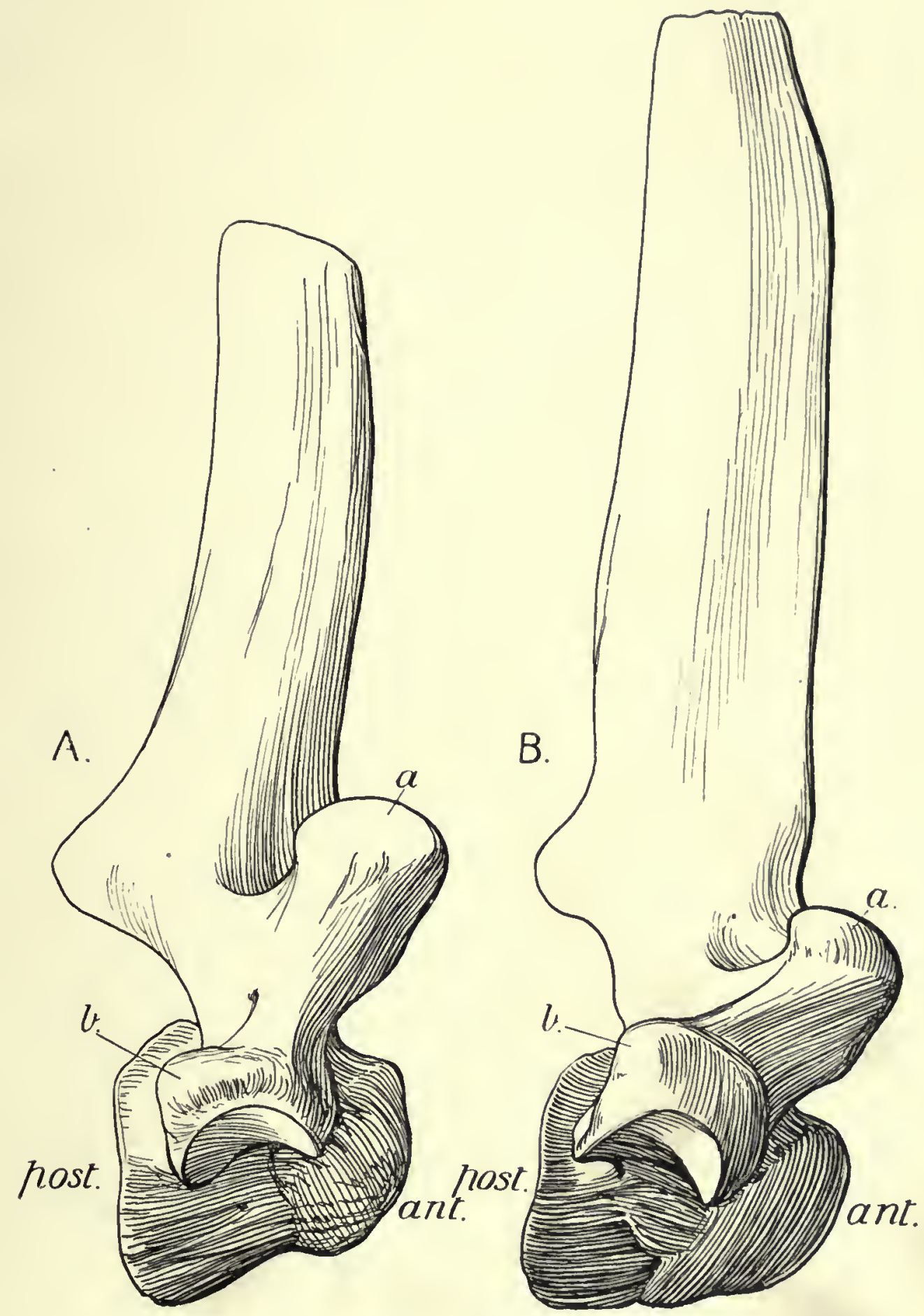

First Dorsal Vertebra of Okapi, right side.

A.-From skeleton in the Hon. Walter Rothschild's muscum at Tring.

B.-From skeleton purchased by the British Muscum of Major Powell-Cotton.

$a$, anterior zygapophysis; $b$, transwerse process. 

Explanation of PLATES 29-40. 


\section{PLATES 29-40.}

The figmres in Plates $29-40$ have been prepared with a view to facilitating a comparative study of the leg-stripes of the Okapis mounted in the varions musenms of Europe. In some cases, as, for instance, in the speeimen presented to the British Museum by Sir Harry Johnston (Plate 29), each leg of the animal is shown in three views, making twelve fignres in all. The sequence of the figures is the same in ench set of six, and where it has not been possible to obtain any particular views of the legs, spaces are left in the series, as, for instance, in Plate 39.

Plates 29-31.-Three specimens at the British Musemm.

Plate 32.- T'wo specimens momted by Mr. Rowland Ward.

Plate 33.--Specimens at Rome and Edinburgl.

Plate 34.- Specimens at Genoa and Madrid.

Plate 35.-Speeimens at Paris, Tervneren, and Madrid.

Plate 36.-Living Okapi calf.

Plate 37.-Two specimens at 'Tervueren.

Plate 38.- Specimens at Lisbon and Terrneren.

Plate 39.- Specimens at Stockholn and Antwerp.

Plate 40.-Specimens at Tring and Carlsrulıe. 


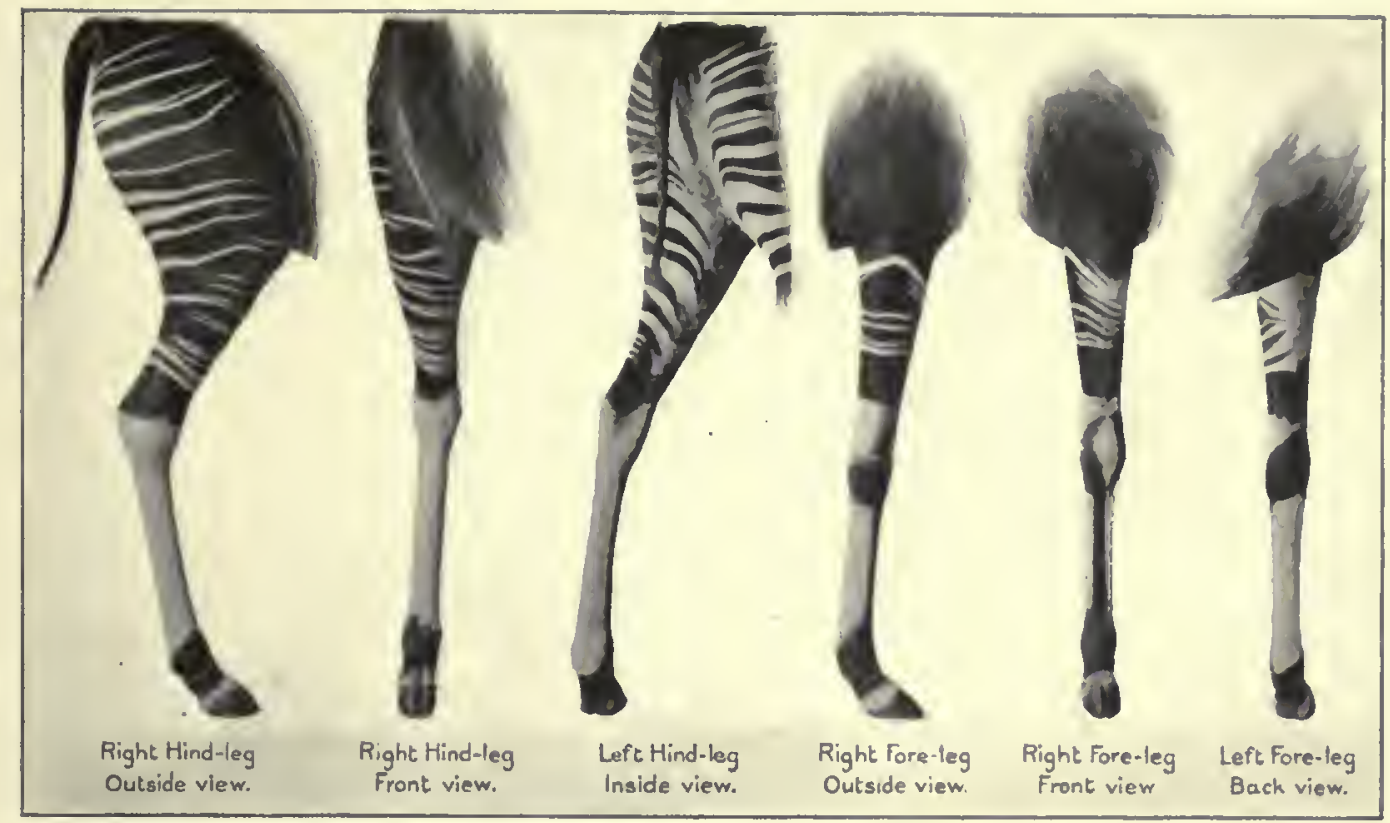

Fig. 1. Specimen in the British Museum (Natural History) presented by Sir Harry Johnston. For the hind leg see also Plate 1, fig. 1. The skull of this animal is that denoted A in Plates 3,8 and 13.

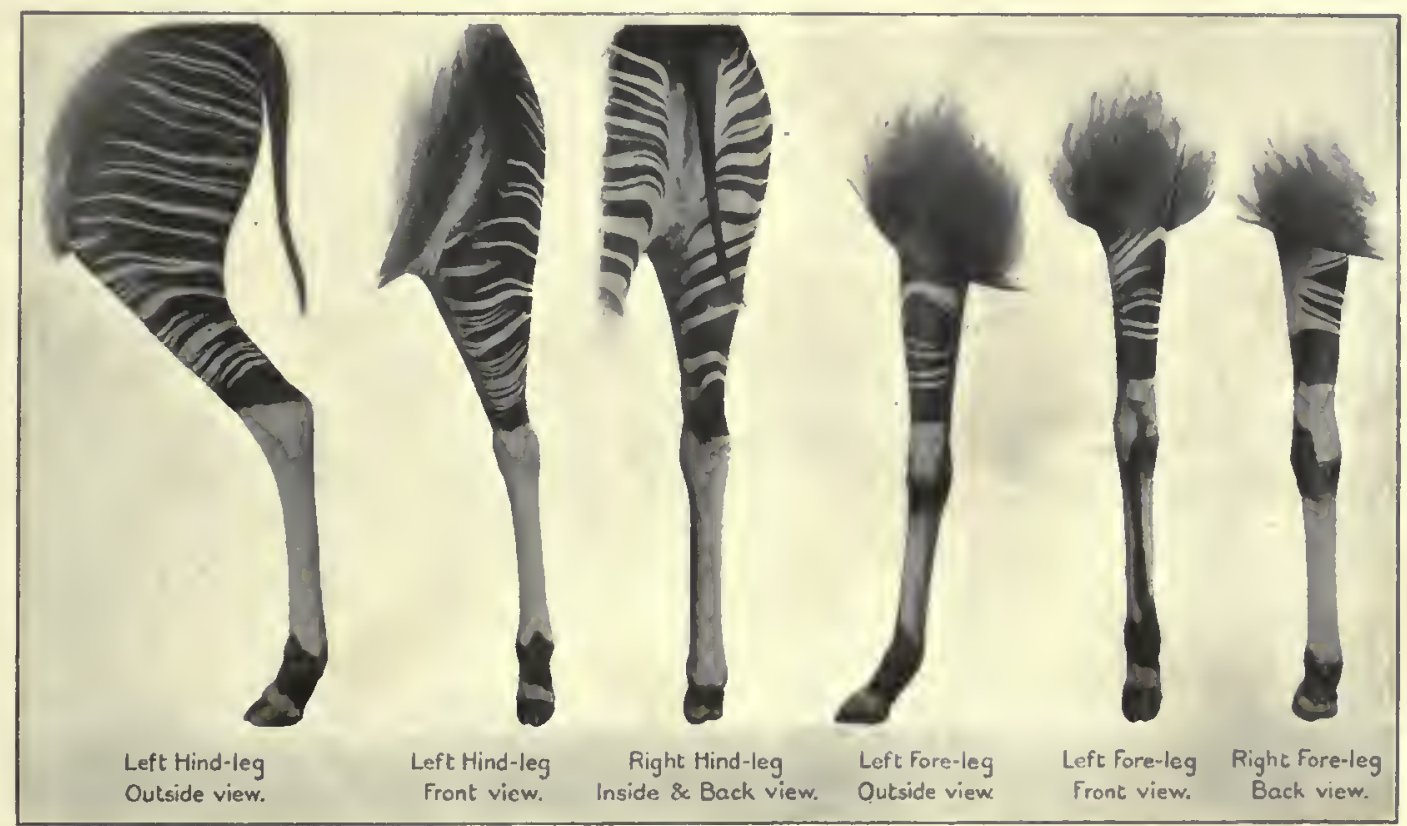

Fig. 2. Same specimen as above. For a figure of the whole animal see Plate 44, fig. 1. 



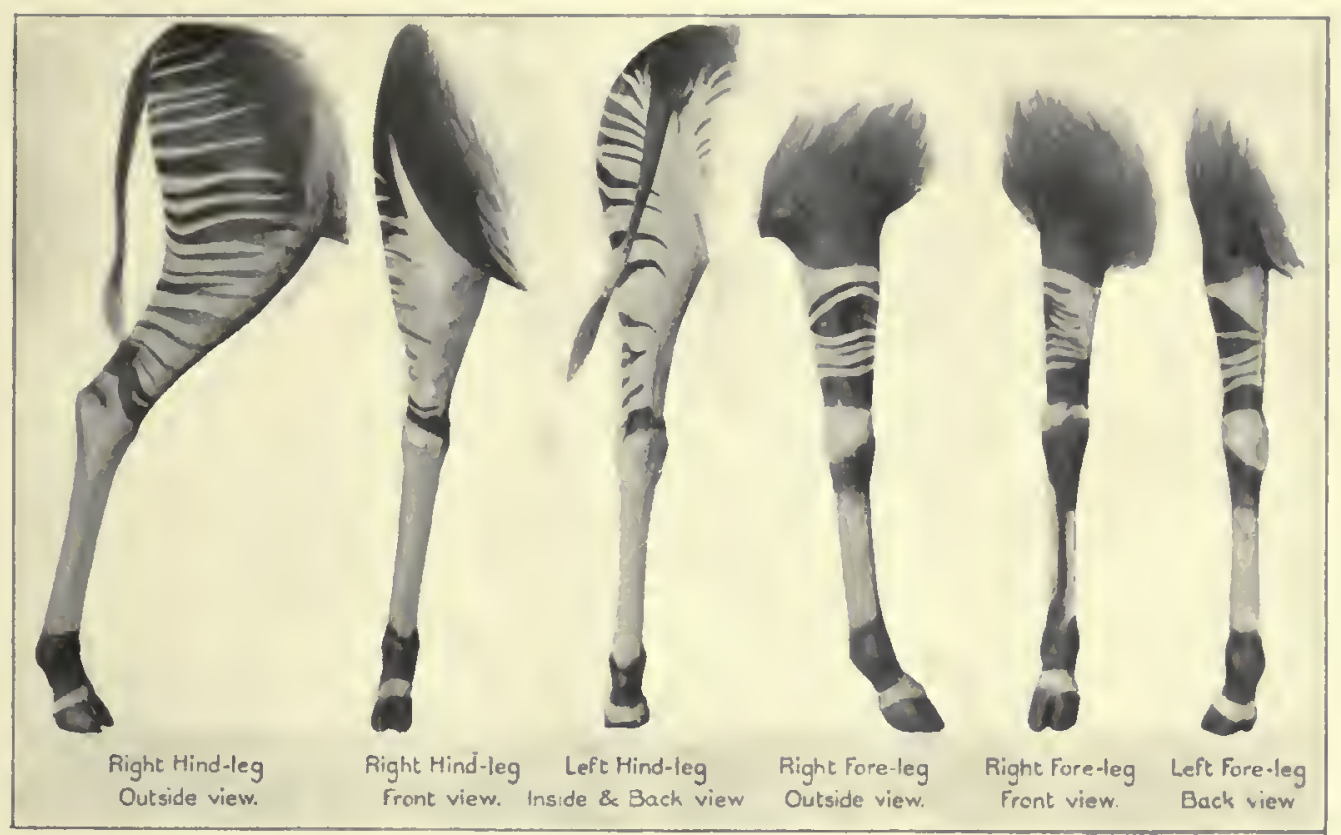

Fig. 1. Specimen in the British Musenm (Natural History) presented by Major Poreell-Cotton. For the hind leg see also Plate 1, fig. 2. The skull of this animal is that denoted B in Plates 3, 7, 9, 13 and 18 .

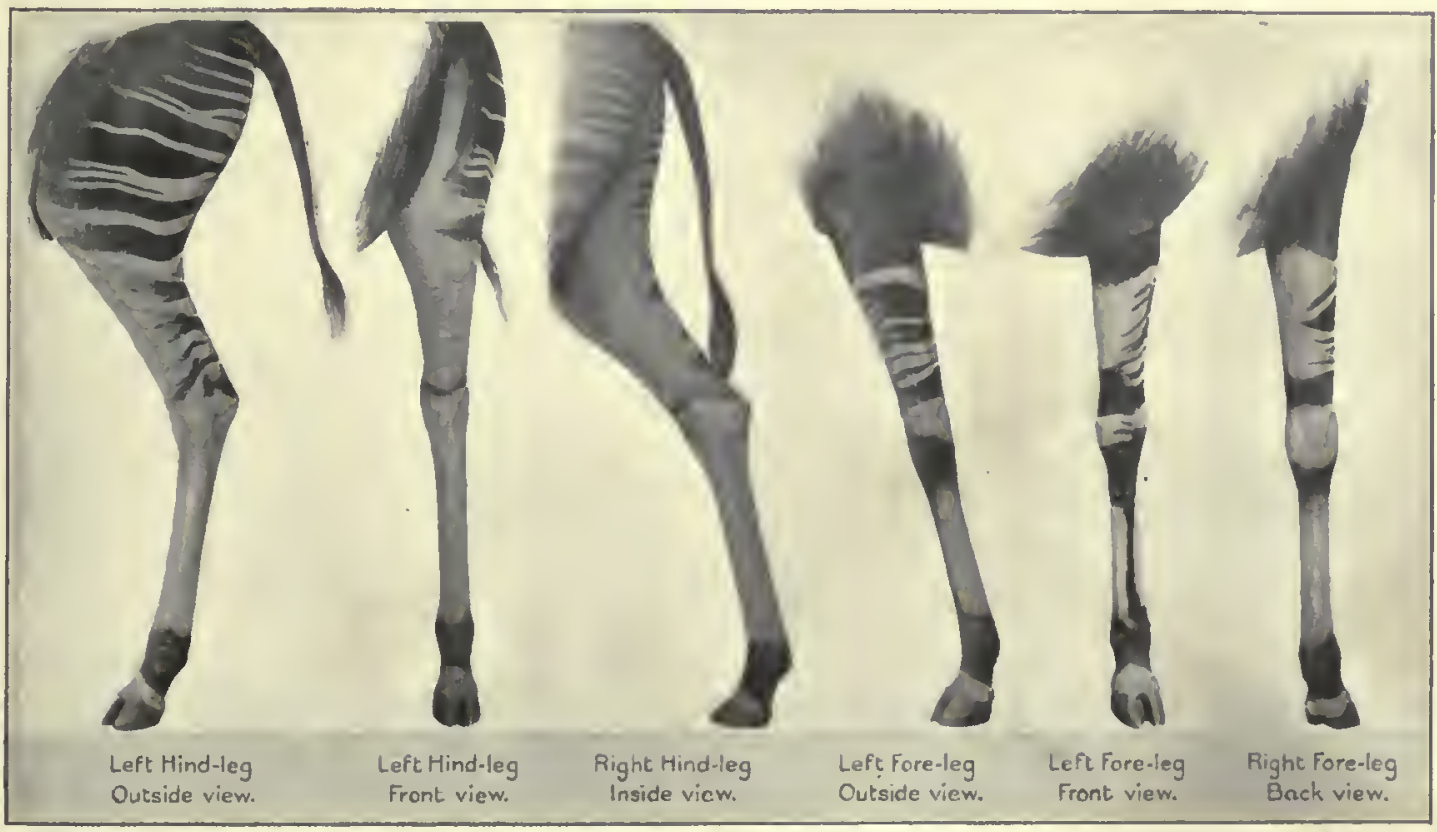

Fig. 2. Same specimen as above. For a figure of the whole animal see Plate 45, fig. 1. 


\section{.}


PLATE 3I.

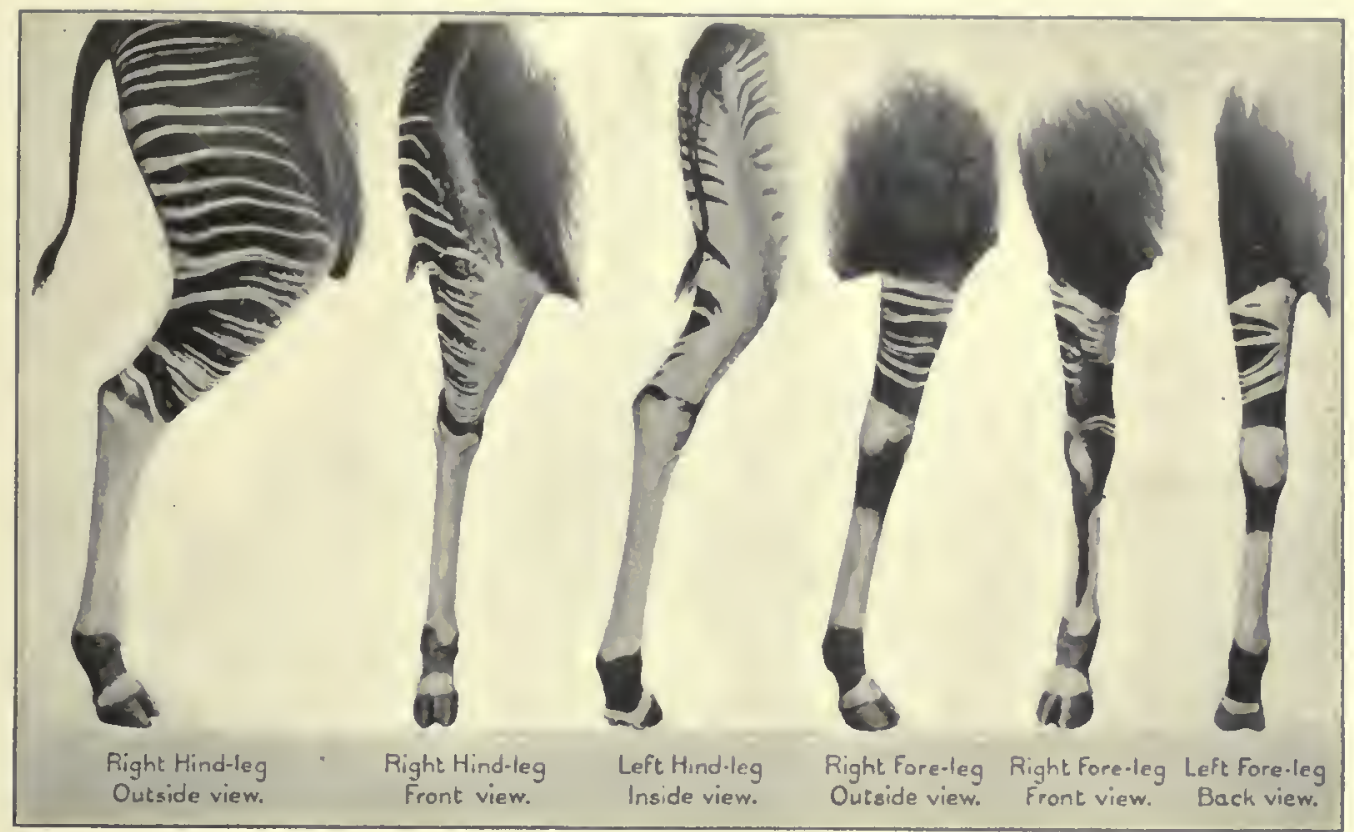

Fig. 1. Specimen in the British Museum (Natural History) presented by the late Mr. Boyd Alexander. For a figure of the whole animal see Plate 44, fig. 2. The skull of this animal is that denoted $D$ in Plates 4, 5, 6, 11 and 14.

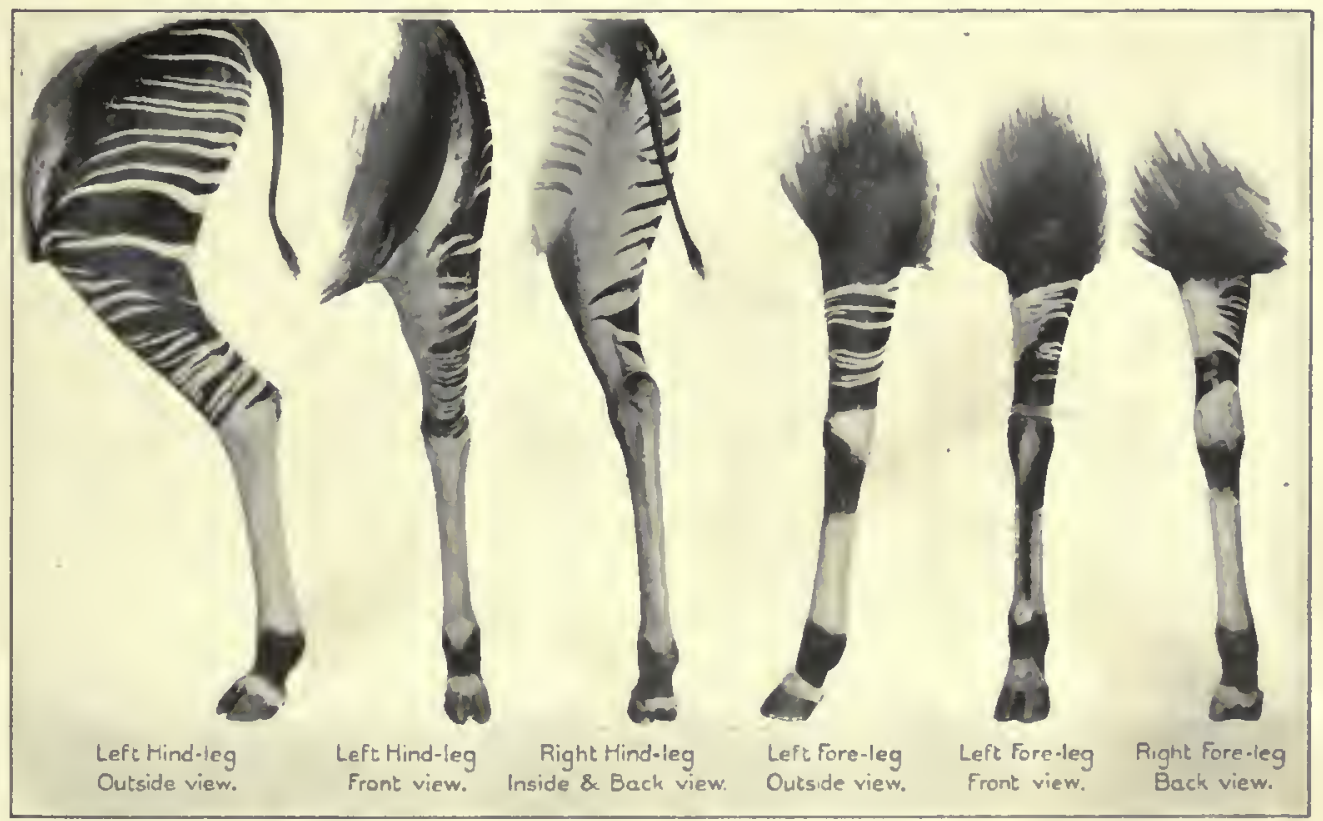

Fig. 2. Same specimen as above. 



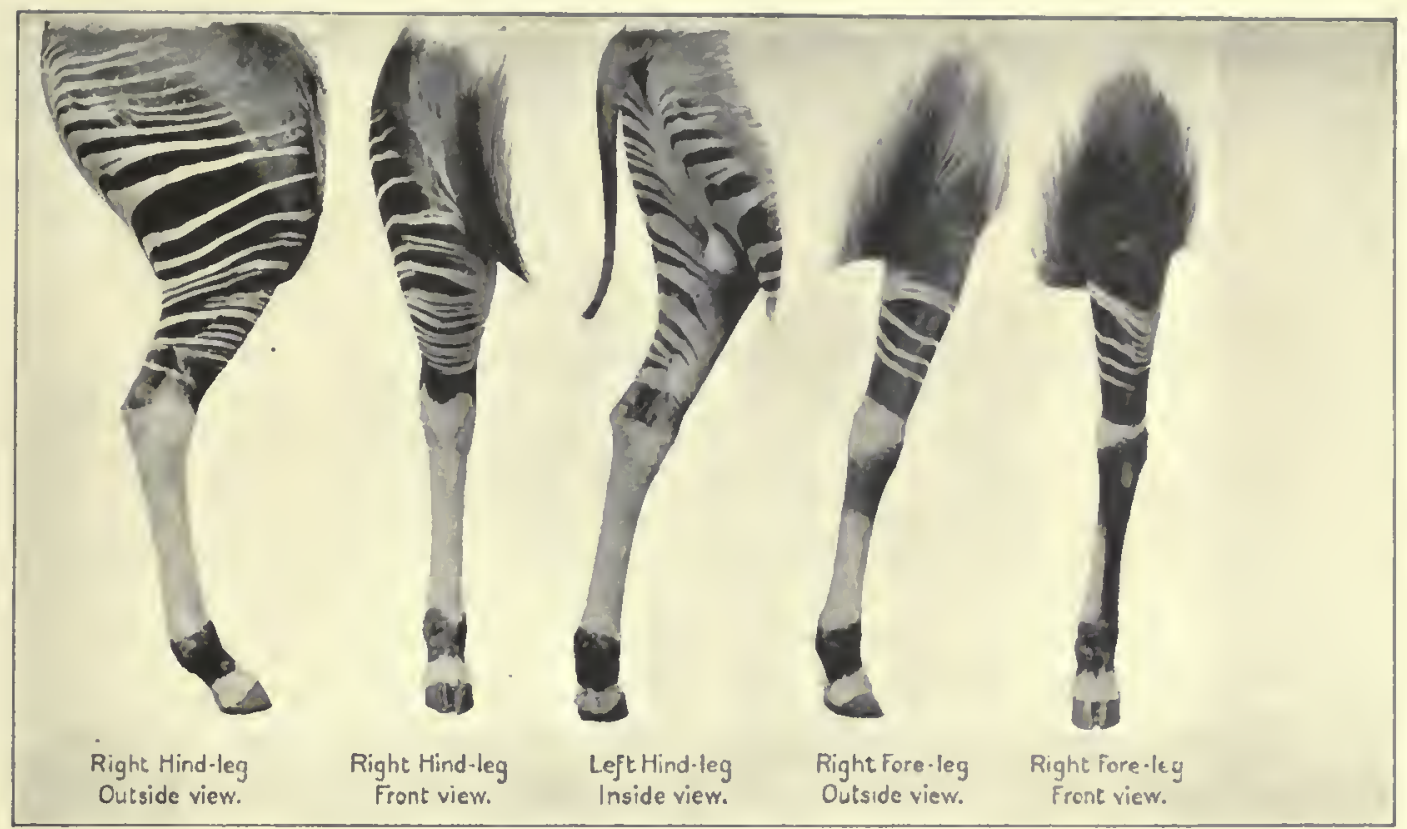

Fig. 1. Specimen monnted by Mr. Rowland Ward, London (No. 1 Specimen), and now in America. Sex doubtful; the animal is mounted as though malc. Irom photographs supplied by Mr. Roucland Ward. The skull of this animal is that denoted $C$ in Plates 4,8 and 13.

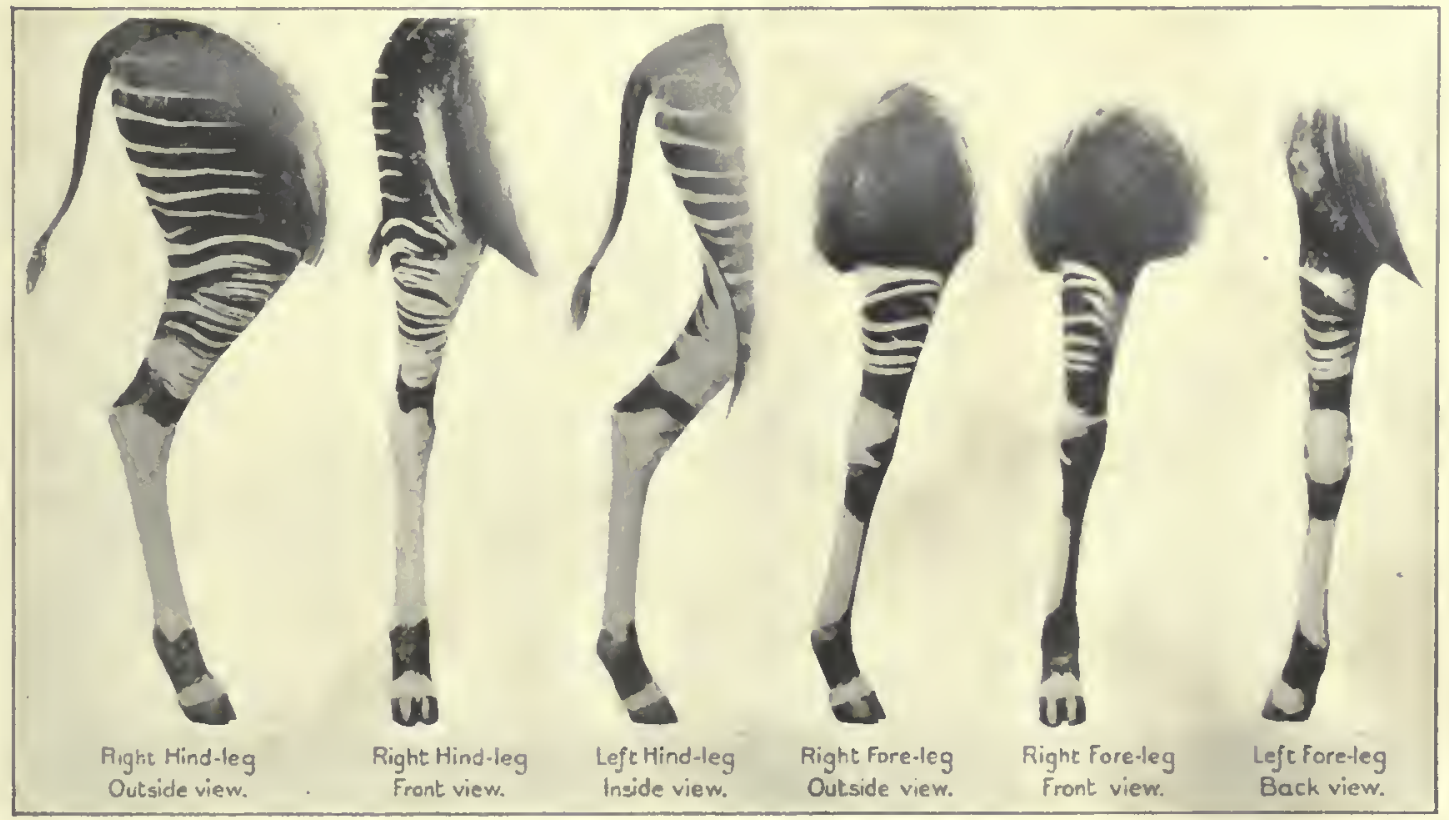

Fig. 2. Another specimen mounted by Mr. Roweland Ward, London (No. 3 Specimcn). From photographs supplied by Mr. Rowland Ward. 



$$
\frac{91401}{91811}
$$


, 


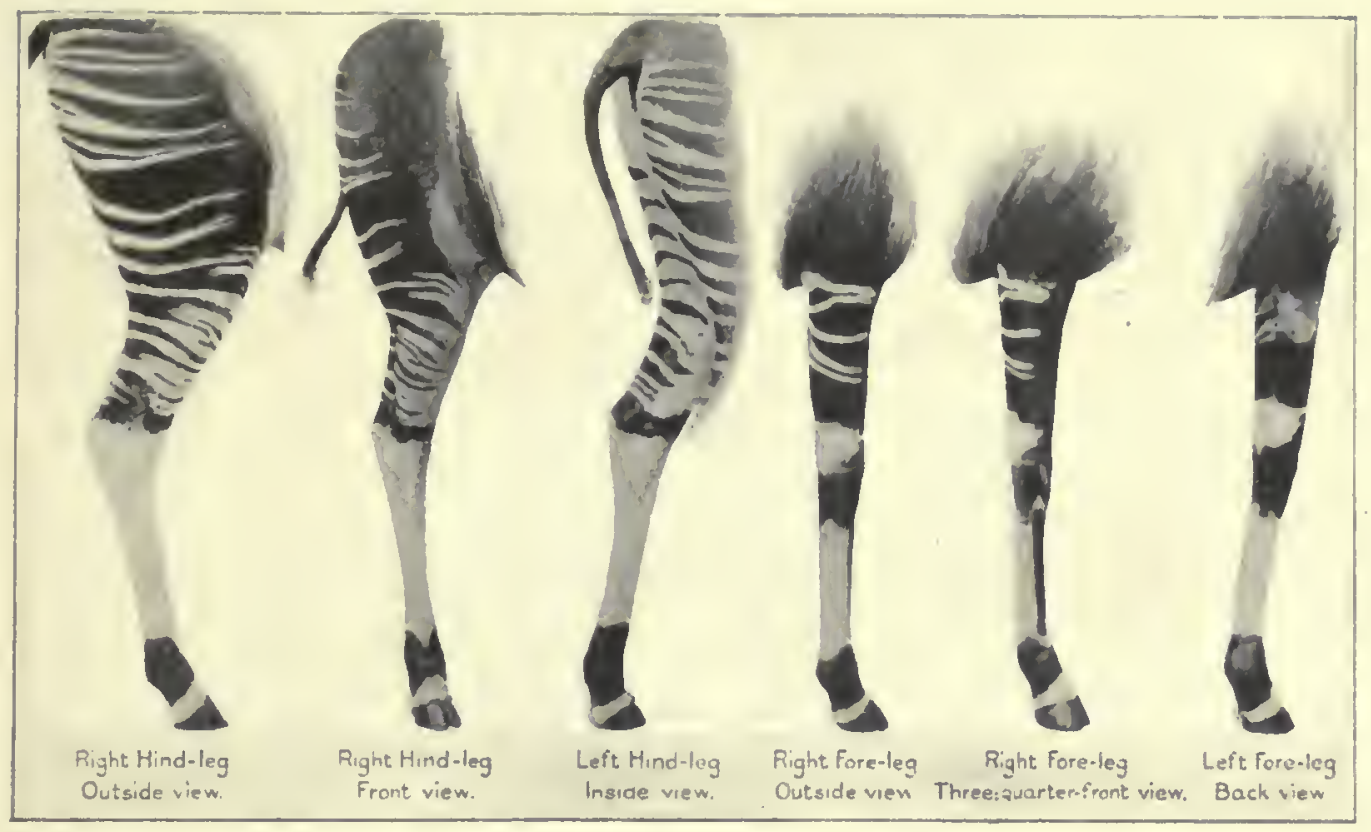

Fig. 1. Specimen in the Genoa Museum (Museo Civico di Storia Naturale); from photographs sutplied by the Genoa Museum. A figure of the whole animal is given by J. Fraipont "Annales du Musée du Congo, Zool.," ser. 2, vol. i, "Okapia," 1907, p. 15, fig. 9; the specimen is mentioned in paragraph 25 on page 15). Skull $O$ in Plate 17 is hornless, and is evidently not the skull of this animal.

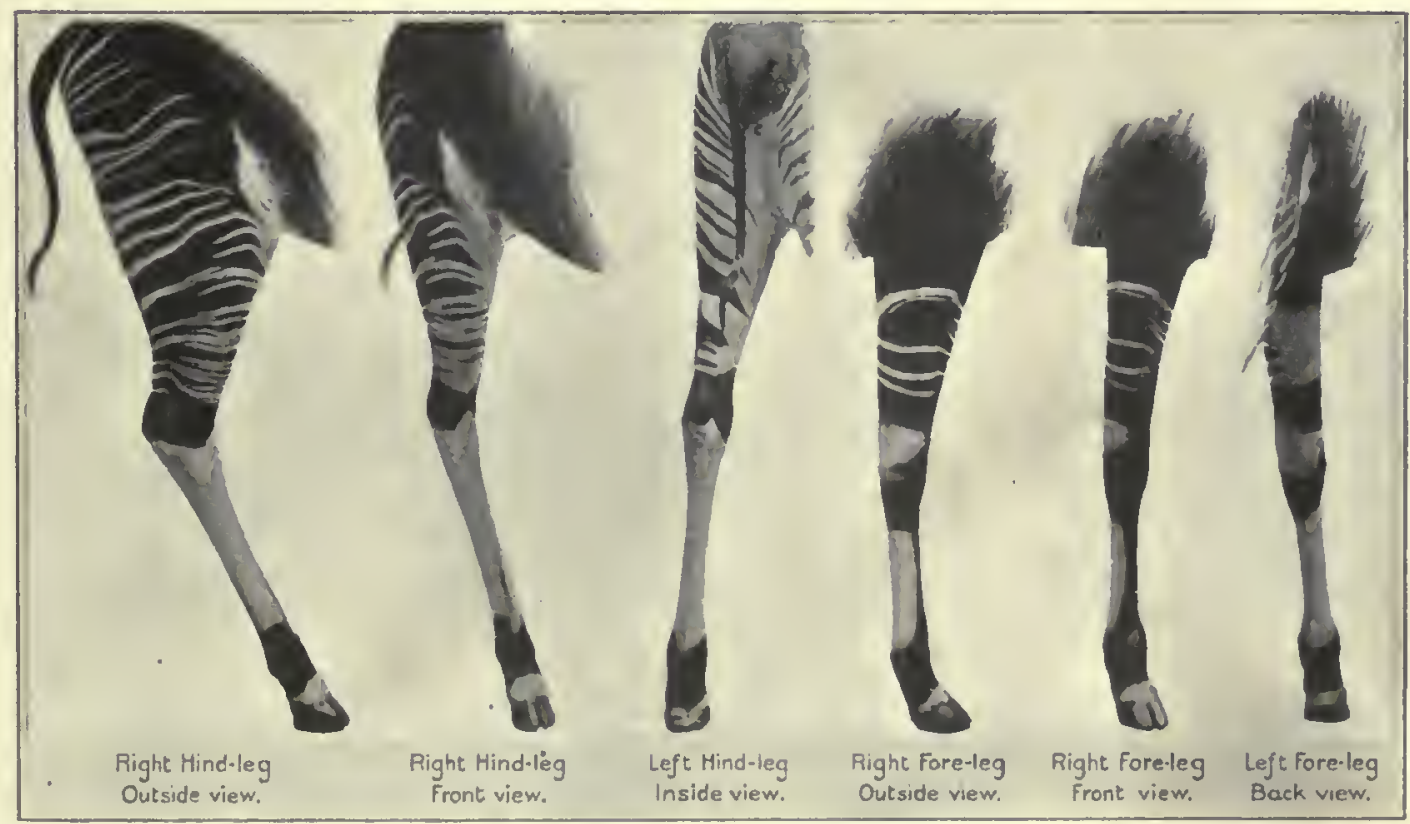

Fig. 2. Specimen in the Madrid Musenm; from photographs supplied by the Madrid Muscum. Half-grown, reputed male; No.705a of J. Fraipont. A figure of the whole animal is given by J. Fraipont ("A muales du Musée du Congo, Zool.,' ser. 2, vol.i, "Okapia," 1907,p. 14, fig. 7). For a back view see Plate 35, fig. 3. Skull $N$ in Plate 17 is hornless, and is evidently not the skull of this animal. 



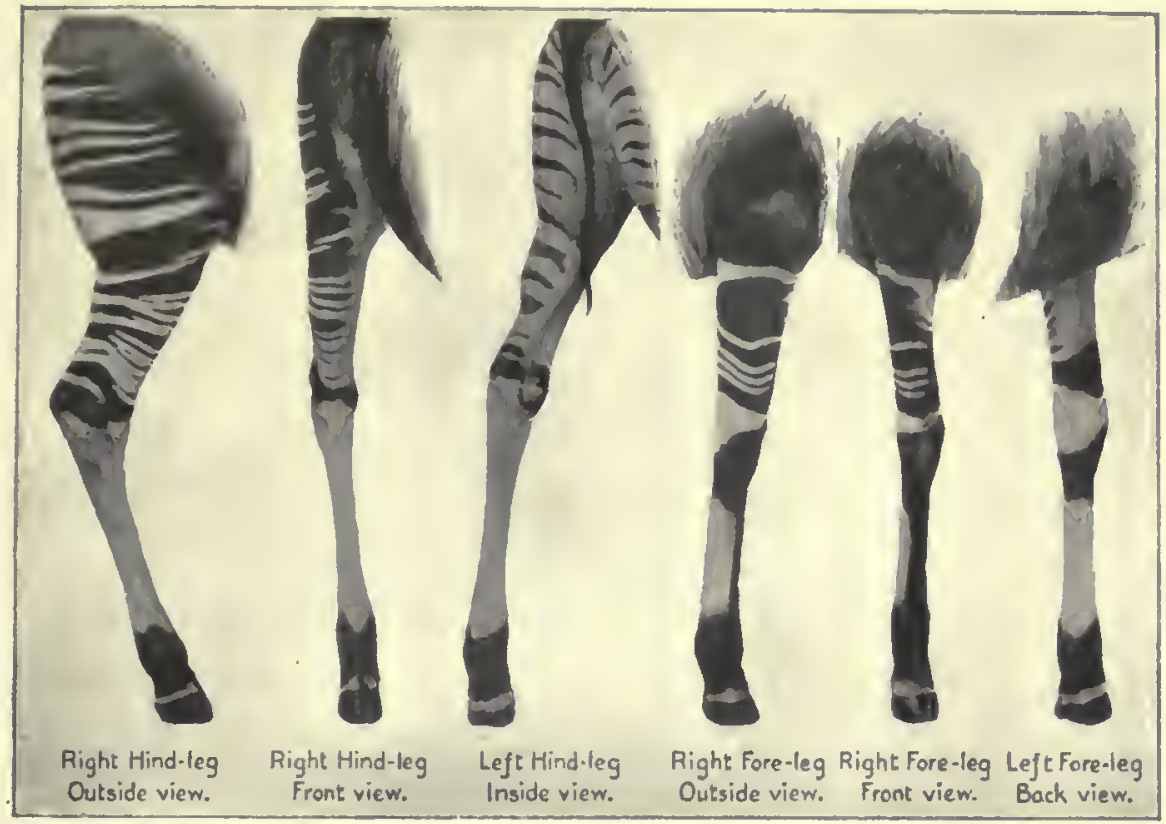

Fig. 1. Specimen in the Paris Muscum (Musćun d'Histoire Naturelle); from photographs supplied by the Paris Muscum; adult, said to be male, No. 503 of J. Fraipont. A figure of the wohole animal is given by J. Fraipont ("Aunales du Musée du Congo, Zool.,' ser. 2, vol. i, "Okapia," 1907, p. 13, fig. 5). A front view is given by $M$. de Rothschild and $H$. Neuville ('Ani. Sci. Nat., Zool.,' ser. 9, vol. $x$, No. 1, 1909 [February, 1910], p. 6, fig. 1). Skull P in Plates 2 and 17 is not the skull of this animal (see Fraipont, b. 14, paragr. 7 and 9).

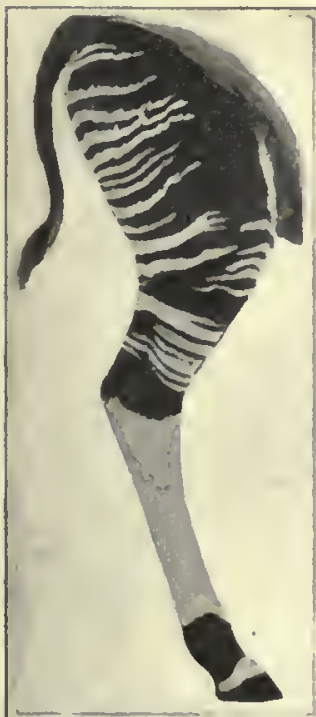

Right Hind-leg Outside view.

Fig. 2. Spccimen in the Tervuercn Museum (Musce du Congo), Bclgium; very young, No. 706 ; figures copied from J. Fraipont ('A muales du Musée du Congo, Zool.,' ser. 2, vol. i, "Okapia," 1907, p. 31, fig. 41, and p. 26, fig. 29 .

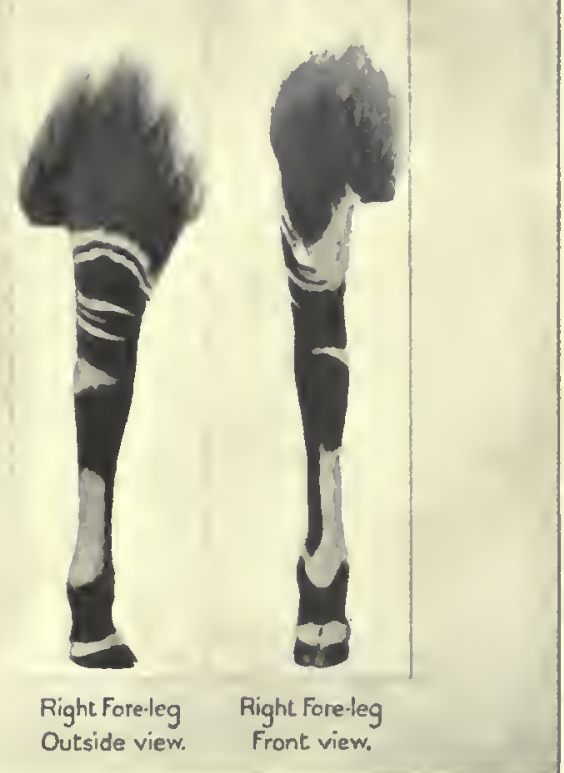

Fig. 3. Specimen in the Matrid Muscum; hind view; from J. Fraipont ("Annales du Muséc du Congo, Zool.,' ser. 2, vol. i, "Okapia," 1907, p. 30, fig. 38). 


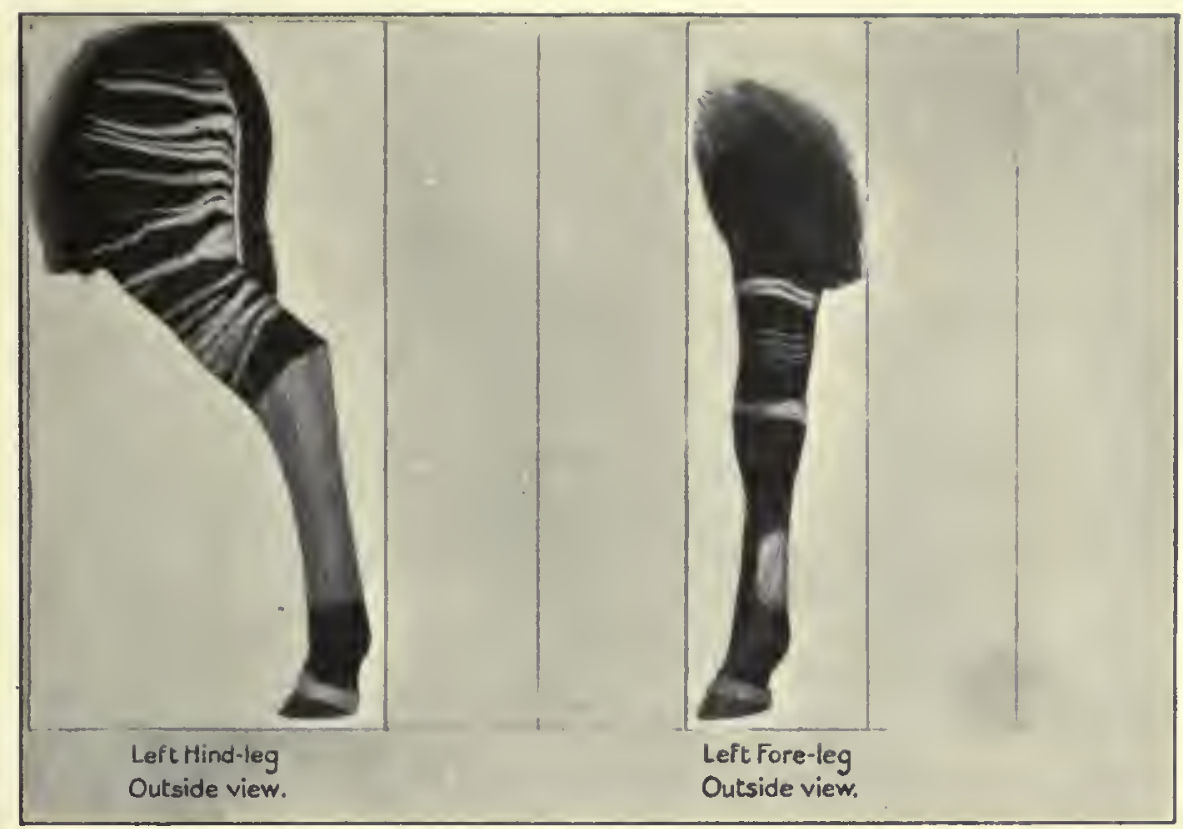

Fig. 1. Specimen of a living Okapi calf, one month old; from a photograph taken by Monsieur Ribotti at Bambili and sent to Sir Ray Lankester by the Marquis Giacomo Doria, of the Genoa Museum. For a figure of the rolzole animal see Plate 46, fig. 1.

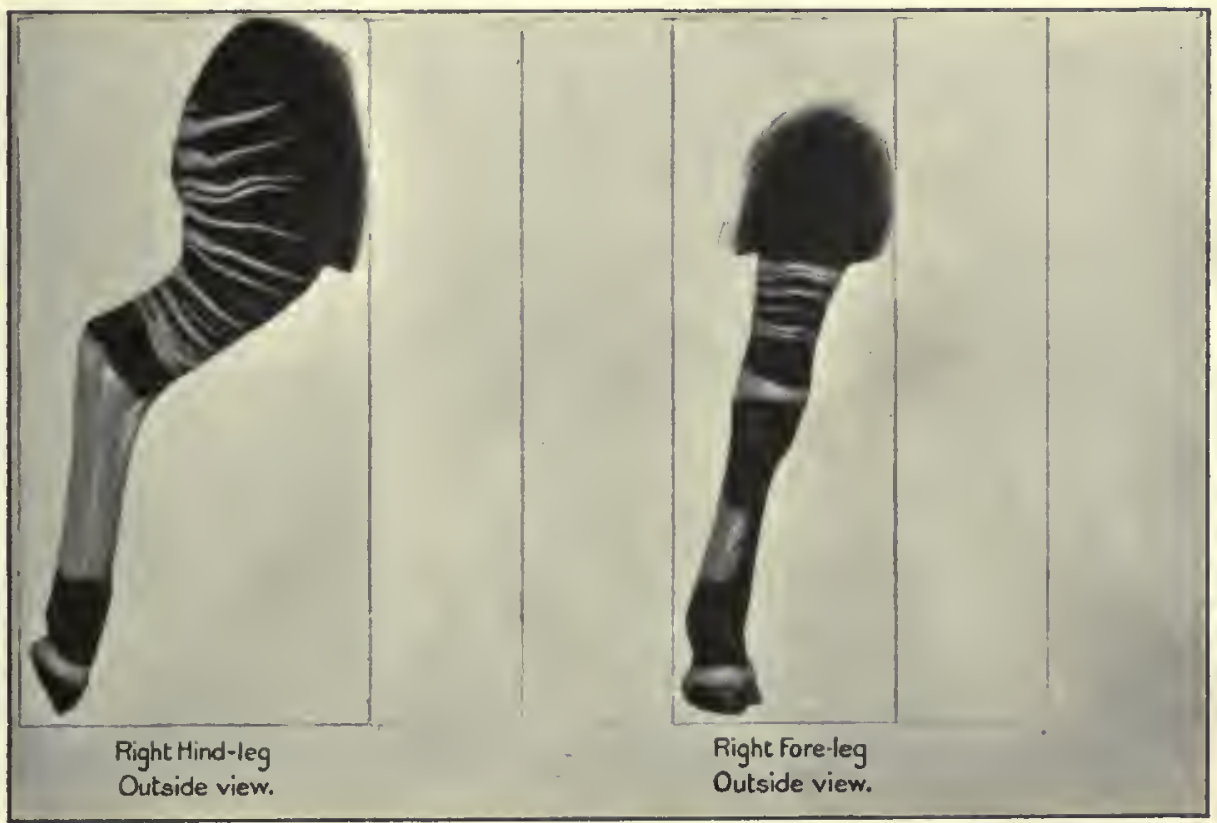

Eig. 2. Same specimen as above. 


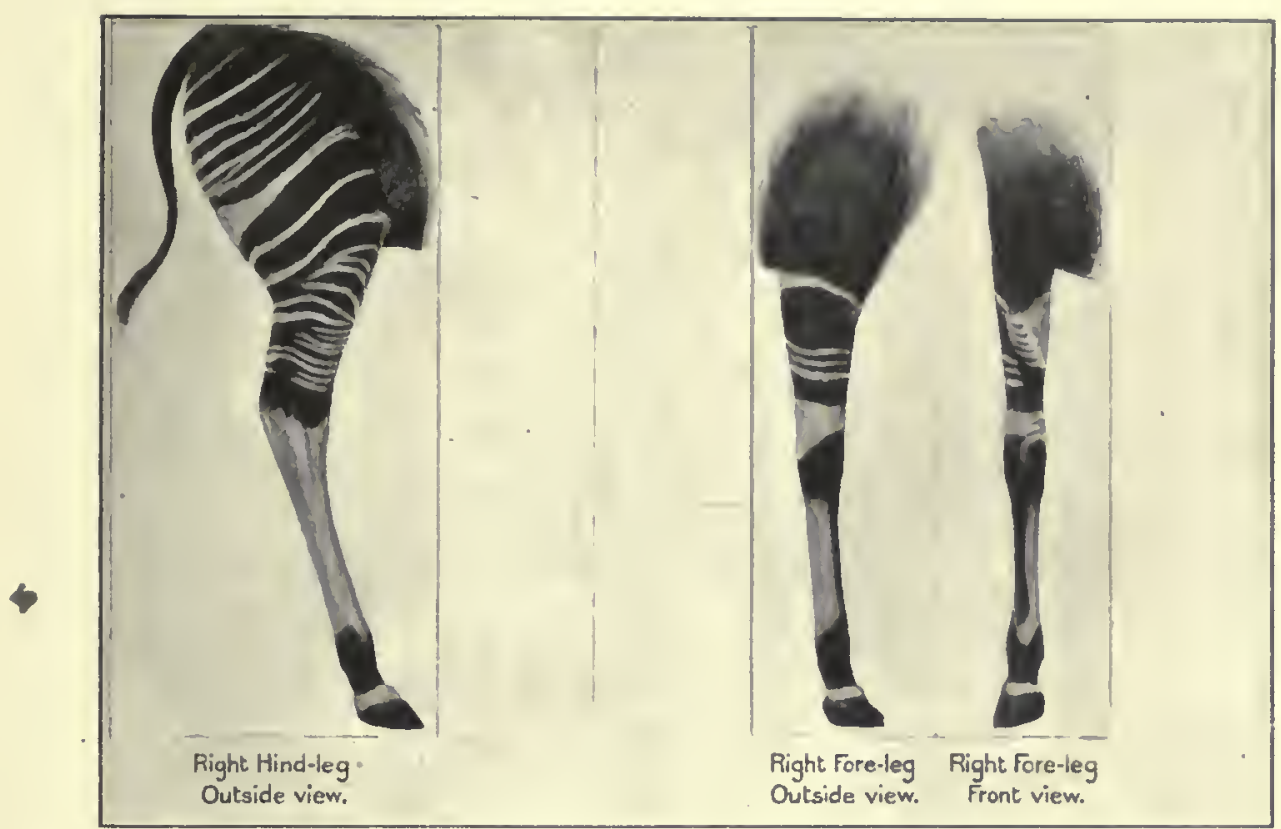

Fig. 1. Specimen in the Tervueren Musenm (Musée du Congo), Belgium; young, said to be fomale; No. 541; figures copicd from J. Fraipont ("Amuales du Musée du Congo, Zool.,' scr. 2, vol. i, "Okapia," 1907, p. 18, fig. 11, and p. 25, fig. 28).

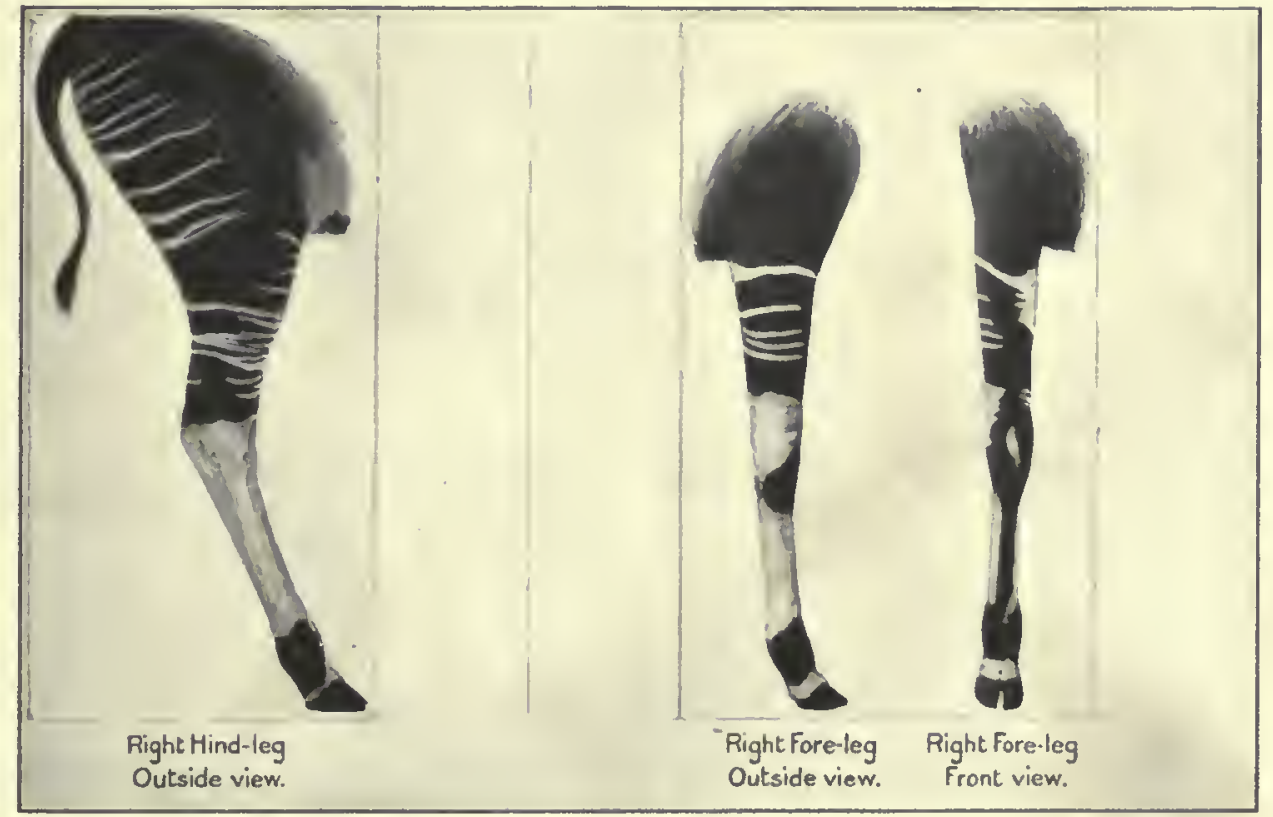

Fig. 2. Specimen in the Tervueven M usenm (Musée du Congo), Belgium; old, said to be female; No. 536; figures copied from J. Fraipont ("Annales du Musée du Congo, Zool.,' ser. 2, vol. i, "Okapia," 1907, p. 23, fig. 22, and p. 24, fig. 25). The skull of this animal is that denoted $N$ in Plate 17 (see Fraipont, p. 14, paragr. 10). 



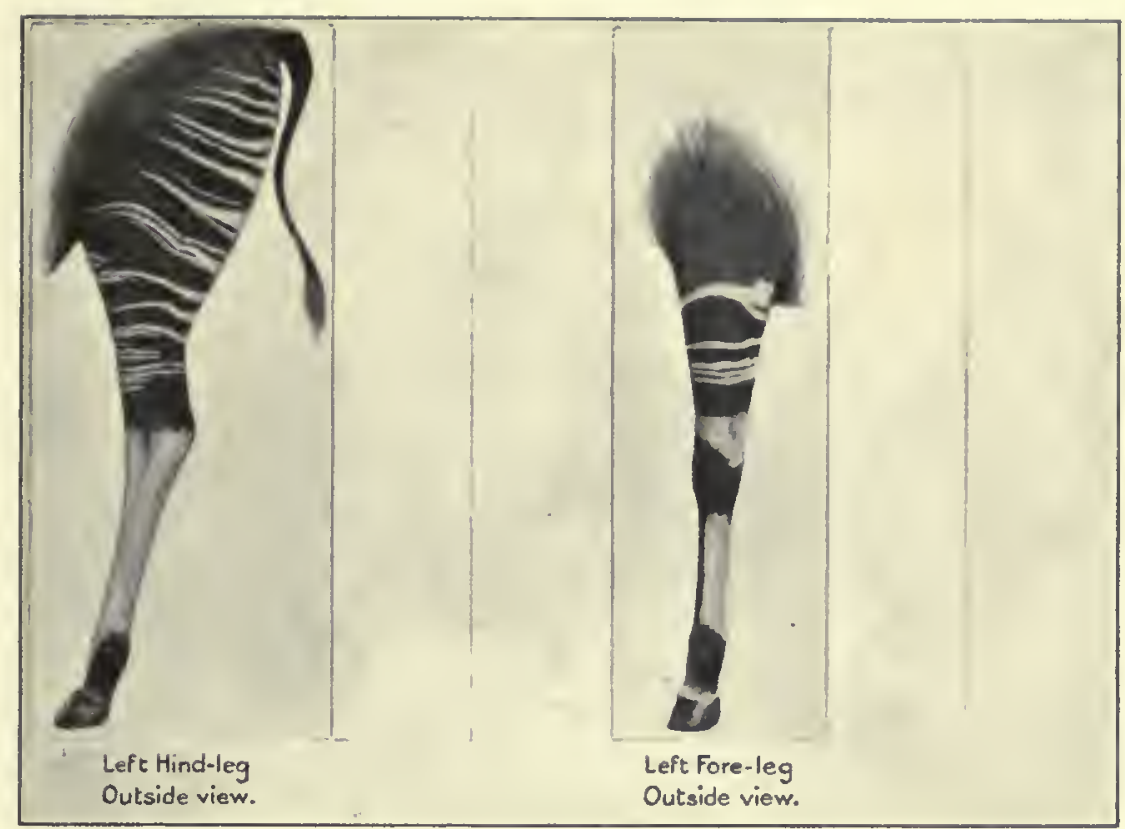

Fig. 1 Specimcn in the Lisbon Museum; adult, said to be female, No. 484 of J. Fraipont; figures copied from J. Fraipont ("Annales du Muséc du Congo, Zool., ser. 2, vol. i, "Okapia," 1907, p. 12, fig. 4).

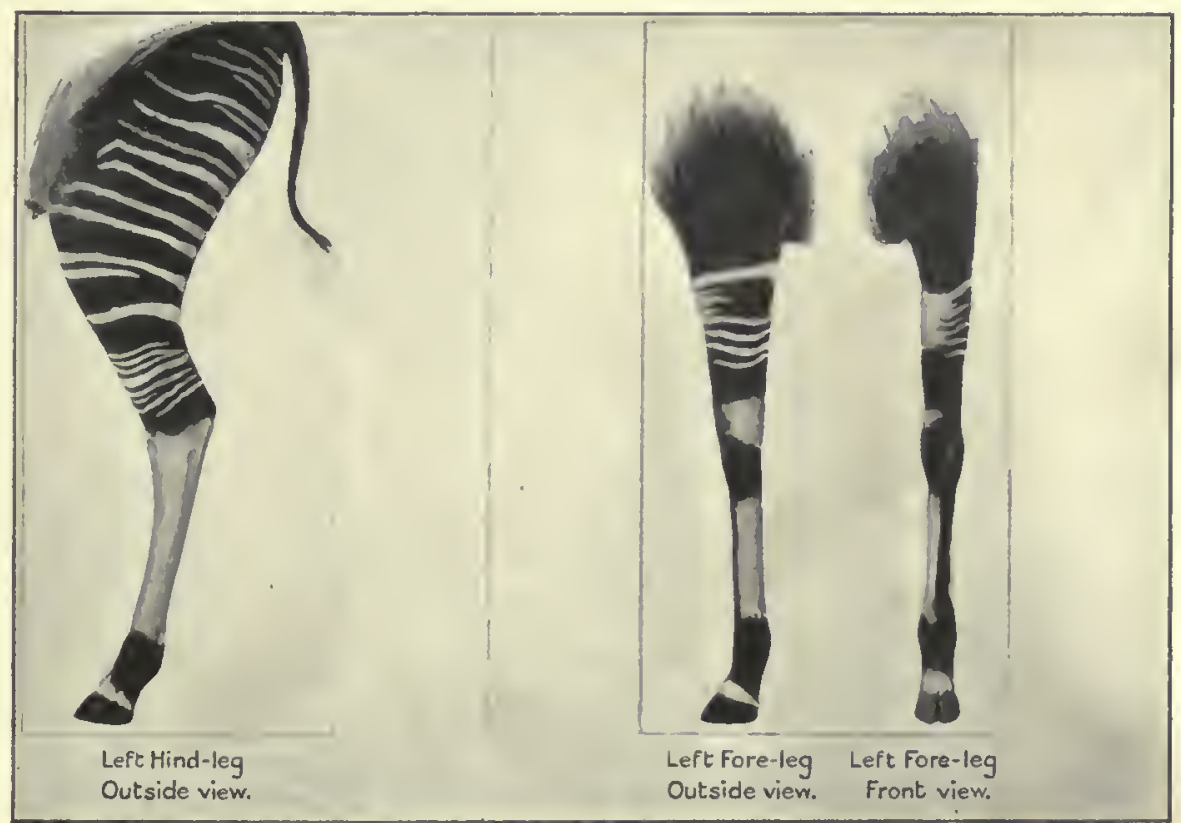

Fig. 2. Specimen in the Tervueren Museum (Mus:c du Congo), Belgium; adult, said to be male, No. 534; figures copied from J. Fraipont ("Annales du Musác du Congo, Zool.,' ser. 2, vol. i, "Okapia," 1907, p. 17, fig. 10, and p. 25, fig. 26). The skull of this animal is that denoted P in Plate 17. 



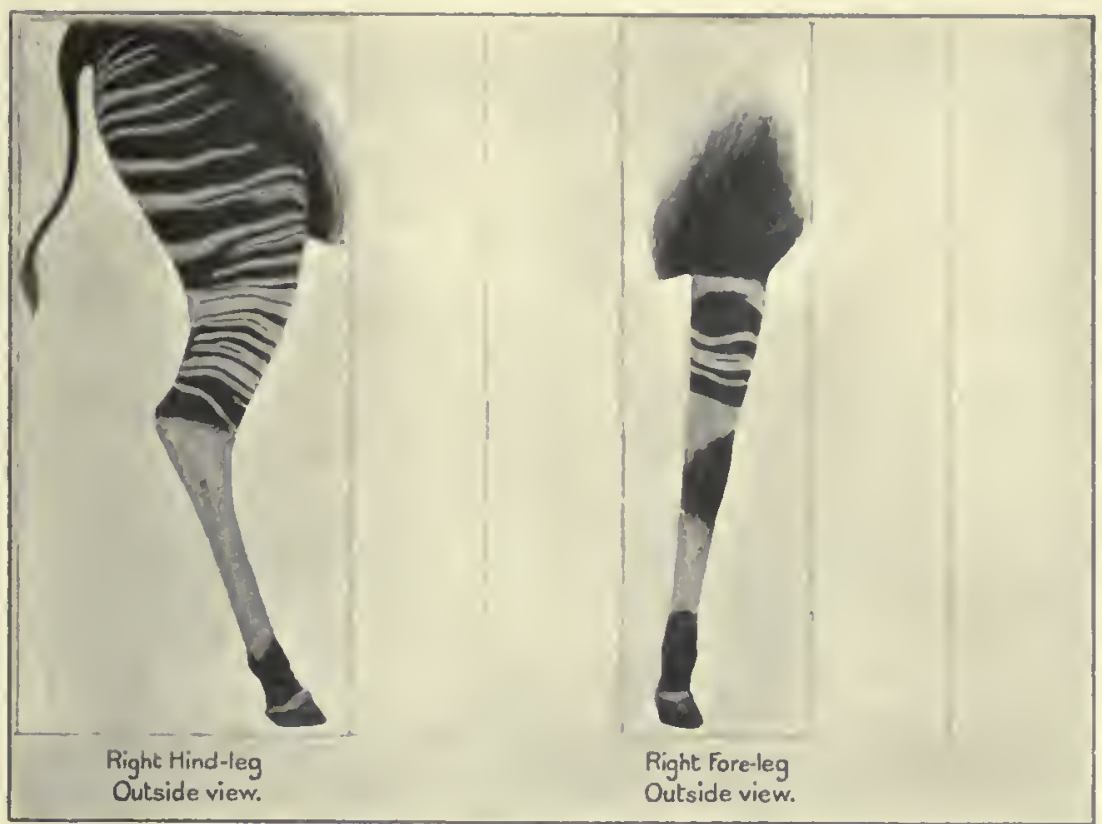

Fig. 1. Specimen in the Stockholn Musenm ; half-grown, said to be male, No. 479 of J. Fraipont; figures copied from J. Fraipont ("Amales du Musée du Congo, Zool.,' ser. 2, vol. i, "Okapia," 1907, p. 11, fig.3). This skin is the paratype of Okapia liebrechtsi, Major, described in 'La Belgique Colonialc,' viii, No. 45, November 9th, 1902, p. 533, but mentioned in 'Proc. Zool. Soc.,' 1902, ii, p. 73, published in October, 1902. Dr. Forsyth Major at the time considered the sex to be female. The type specimen of the species is the skull of an older Okapi, No. 480 of Frapiont. See remarks on Skull $L$ in the pages preceding Plate 13.

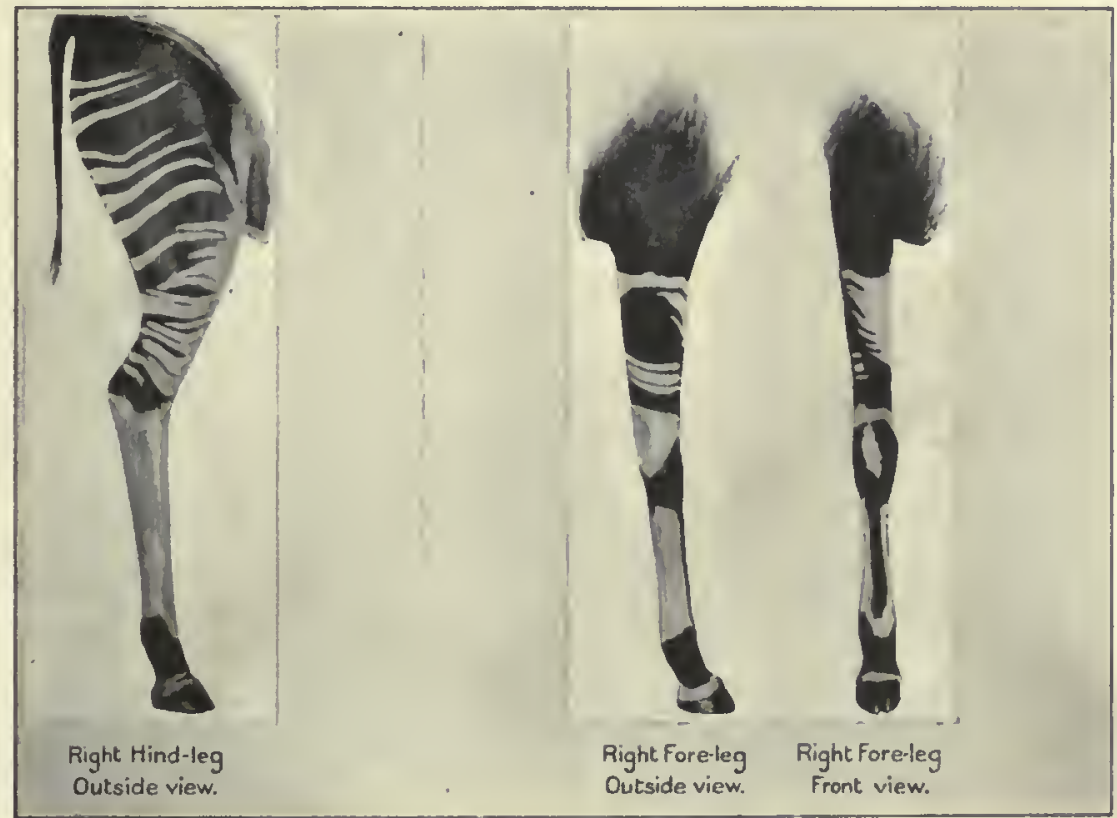

Fig. 2. Specimen in the Antweerp Musenn (Societe Royale de Zoologie); adult, said to be male, No. 532 of J. Fraipont; figures copied from J. Fraipont ('Annales du Mus'́c du Congo, Zool.,' ser. 2, vol. i, "Okapia," 1907, p. 15, fig. 8, and p. 24, fig. 24). A figure of this specinnen we'as published in 1904 by L.F. de Panw ('Am. Soc. Roy. Zool. Malacol. Belg.,' 1904, p. clxiv). The corresponding skeleton is mounted in the Antreerp Museum, and is figured by Fraipont (l.c., plate xii). 



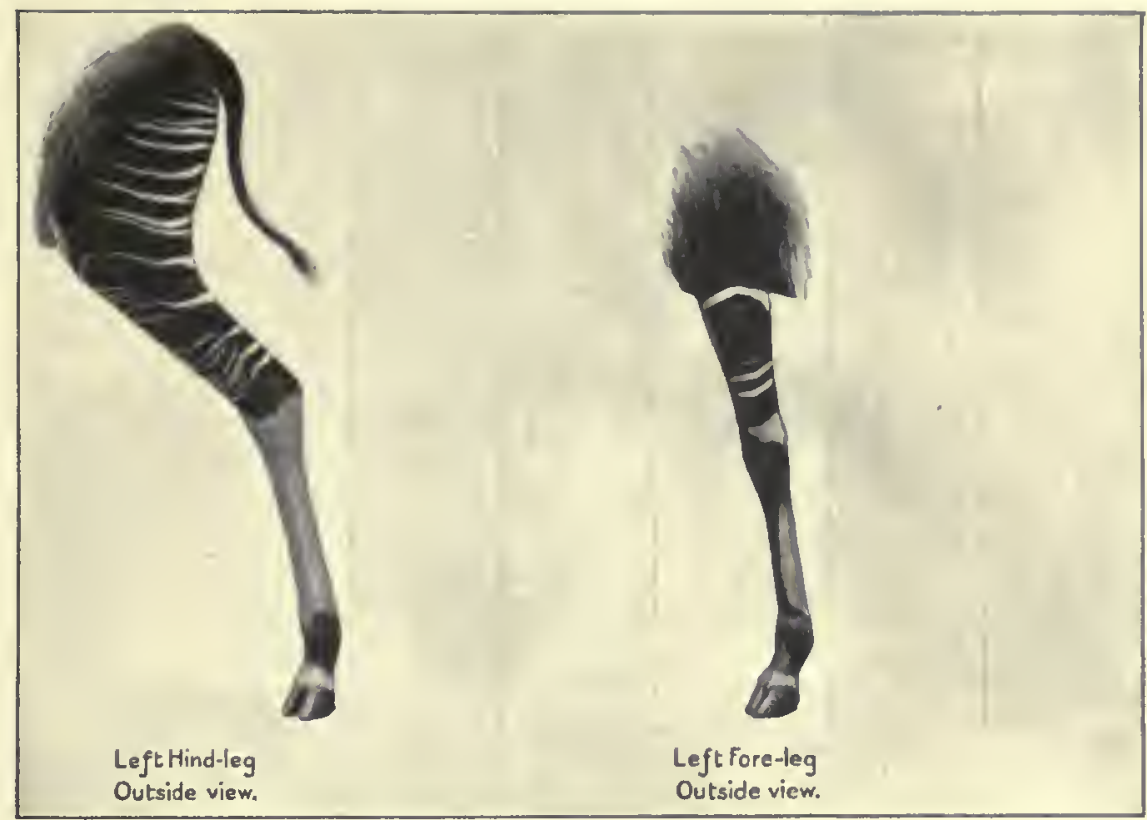

Fig. 1. Specincu in the Hon. Walter Rothschild's museum at Tring; jrom a photograph supplied by Mr. Rothsehild. For a figure of the whole animal see Plate 46, fig. 2. The skull of this specimen is that denoted $F$ in Plates 7 and 14.

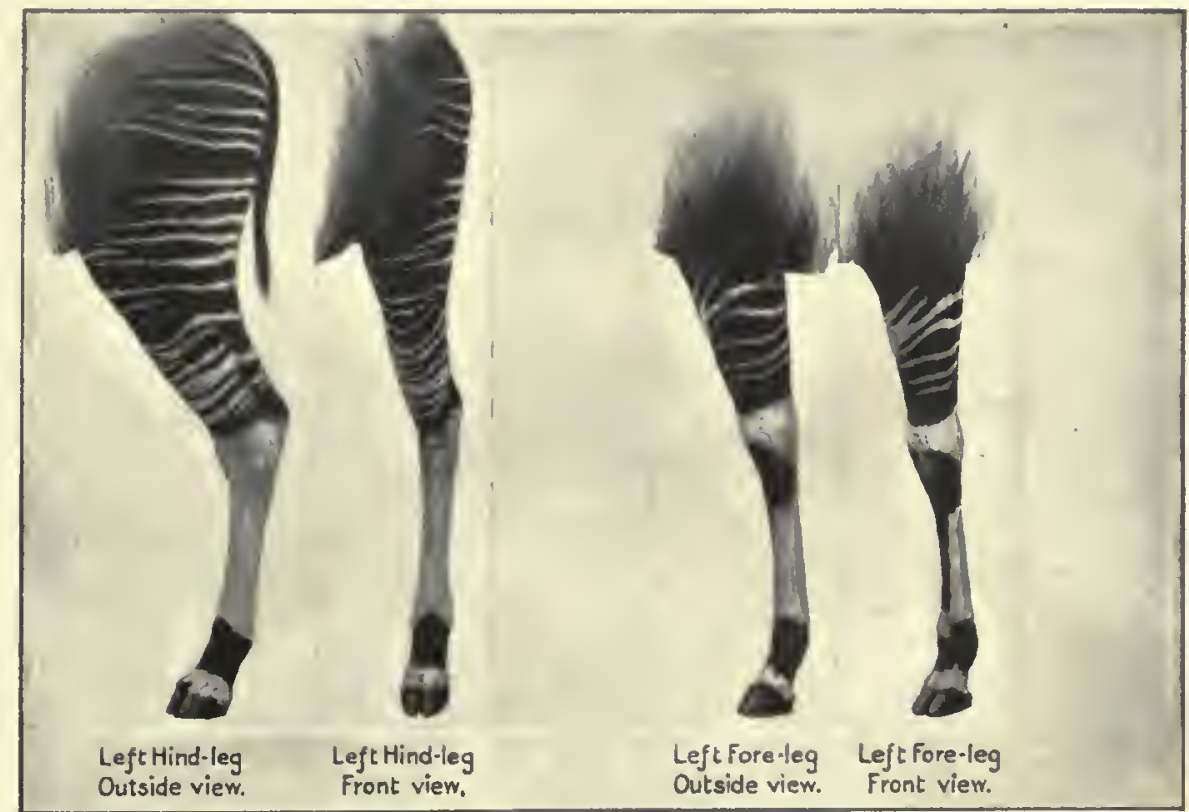

Fig. 2. Specimen in the Museum of Carlsruhe, Baden; from photographs supplied by the Carlsruhe Museum. 


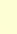


Explanation of PLATES 41, 42, and 43 (fig. 1). 


\section{PLATES 41, 42, axd 43 (Fig. 1).}

A series of thirty-three bandoliers ent by natives from Okapi skin, eliefly from the striped region of the hind leg. Lent by Major Powell-Cotton. [A pair of similar bandoliers sent by Sir Harry Johnston to Dr. P. L. Sclater in 1900, and figmred by him in the 'Proceedings of the Zoological Soeiety,' 1901, i, p. 51, are reproduced in colour in Plate 1. 'These bandoliers are the two co-types of Etgurs (\%) johnstoni, Sclater, a name subsequently altered to Olapie johnstoni by Lankester ('Proc. Zool. Soc.,' 1901, ii, 1. 2\$1).]

The rule to the left of the figures is marked in inches and fect on the left-hand edge and in centinetres on the right.

PI.A'TE 41.

Fig. 1.-Bandolier's A-H. The collector's labels for A-E read "Congo, Kangi, No. "3, Male, hind leg." $F$ is marked "Congo, Kangi, young, from Kasindi, 18.8.0-.". G and H, "Congo, Kangi, yonng, same beast, sent off 16.9.06."

Fig. 2.-Bandoliers I-N. I bear's collector's label "Congo, Kangi, No. 5, by Majura, Mawambe-Auskube." J, “Fort Portal, 28.10.05, Ouex, 27.12.05, 277, Congo, Kangi, No. 5, by Llajura." I and J arrived tied together, with a common label "two bits from same beast, one other bit, label lost." K and L are similarly marked "same beast"; also M and N. K, "Congo, Kangi, No. 1, fenlale, buttock." L, "Congo, Kangi, No. 1, female, hind leg." M and $\mathrm{N}$, "Congo, Kangi, Mawambe-Auskube, four bits by Lencla, these two pieces almost fit."

\section{PLATE 42.}

Fig. 1.-Bandoliers $\mathrm{O}-\mathrm{V} . \quad \mathrm{O}$ and $\mathrm{P}$ bear collector's label, "Congo, Kangi, from Kasinli, 18.8.06, these two join." Q, R and S, "Congo, Kangi, sent off 16.9.06, probably the same beast." 'I, U and V, "Congo, Kangi, six of these threc bits, one belongs to No. 3, and one to No. 5 .

Fig. 2.-Bandoliers W-Ce. W, X, Y and Cc bear similar labels, "Congo, Kangi, No. :, male, fore-leg," and Aa, "Congo, Kangi, No. 3, male." Attached to W is a label, "Ten pieces of a male Okapi (all same beast). There is one other bit, but label lost. Some of these probably fit together." Althongh the label is attached to $W$ only, it jrohably applies also to A, B, C, D, E, X, Y, Aa and Ce, all of whieh, with W, are marked "Kangi, No. :3, male"; possibly it applies also to either 'T, U or V, one of which is said to belong to No. 3. 'This, of course, makes more than the "ten pieces." Z, "Congo, Kangi, No. 2, female, Juttock, no other bit of skin of this beast." Bb, "Congo, Kangi, fonr bits ly Lenda, Mawambe-Auskube"; two other of the "fonr bits by Lenda" are evidently $\mathrm{M}$ and $\mathrm{N}$.

PLATE 4.3.

Fig. 1.-Bandolicrs Dd-Gg. These hear the name "Powell-Cotton"; and in addition Ee bears the label "Strip from for'e-leg." No other particulars are available. 


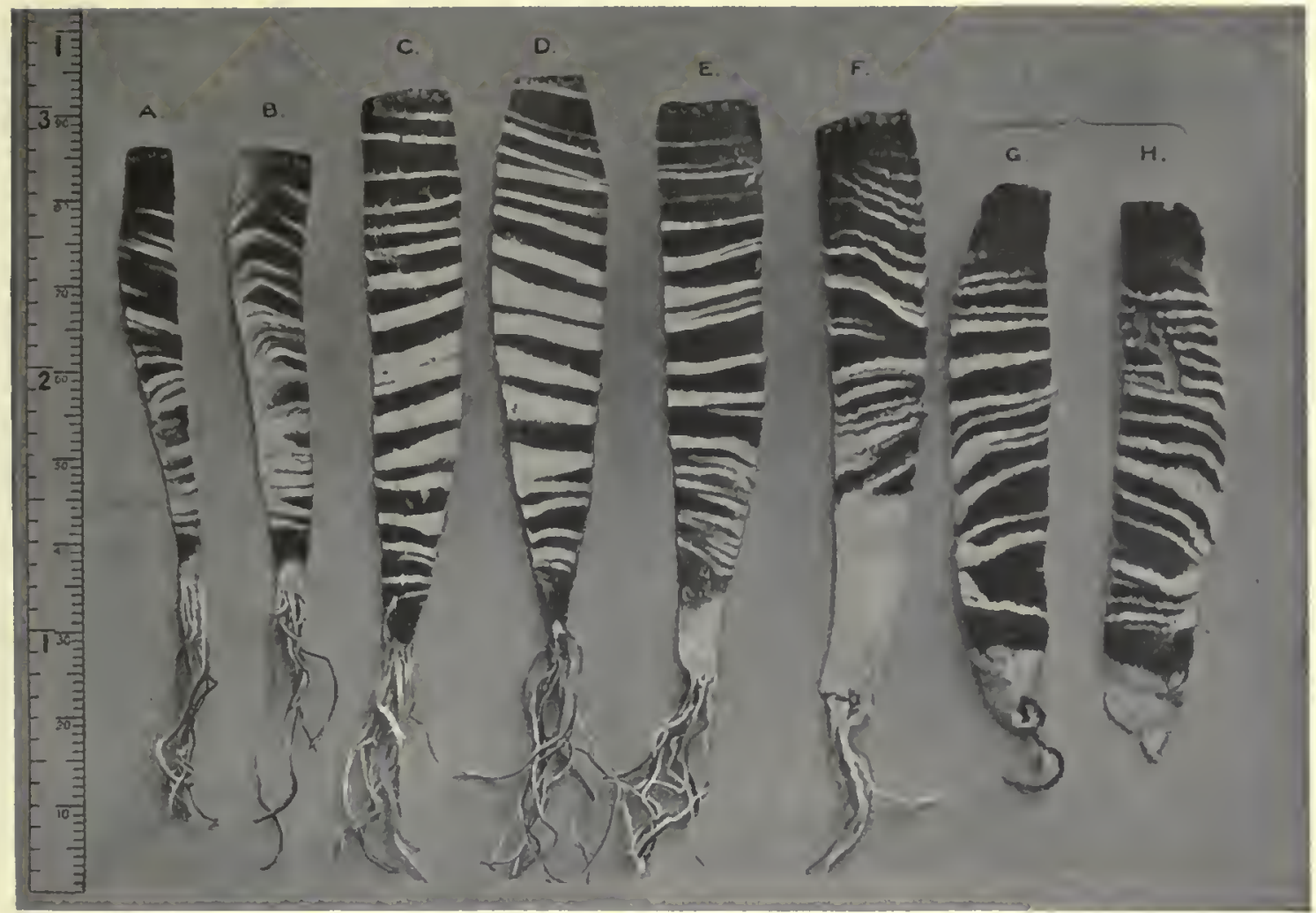

Fig. 1. Bandoliers of Okapi skin, lent by Major Powell-Cotton.

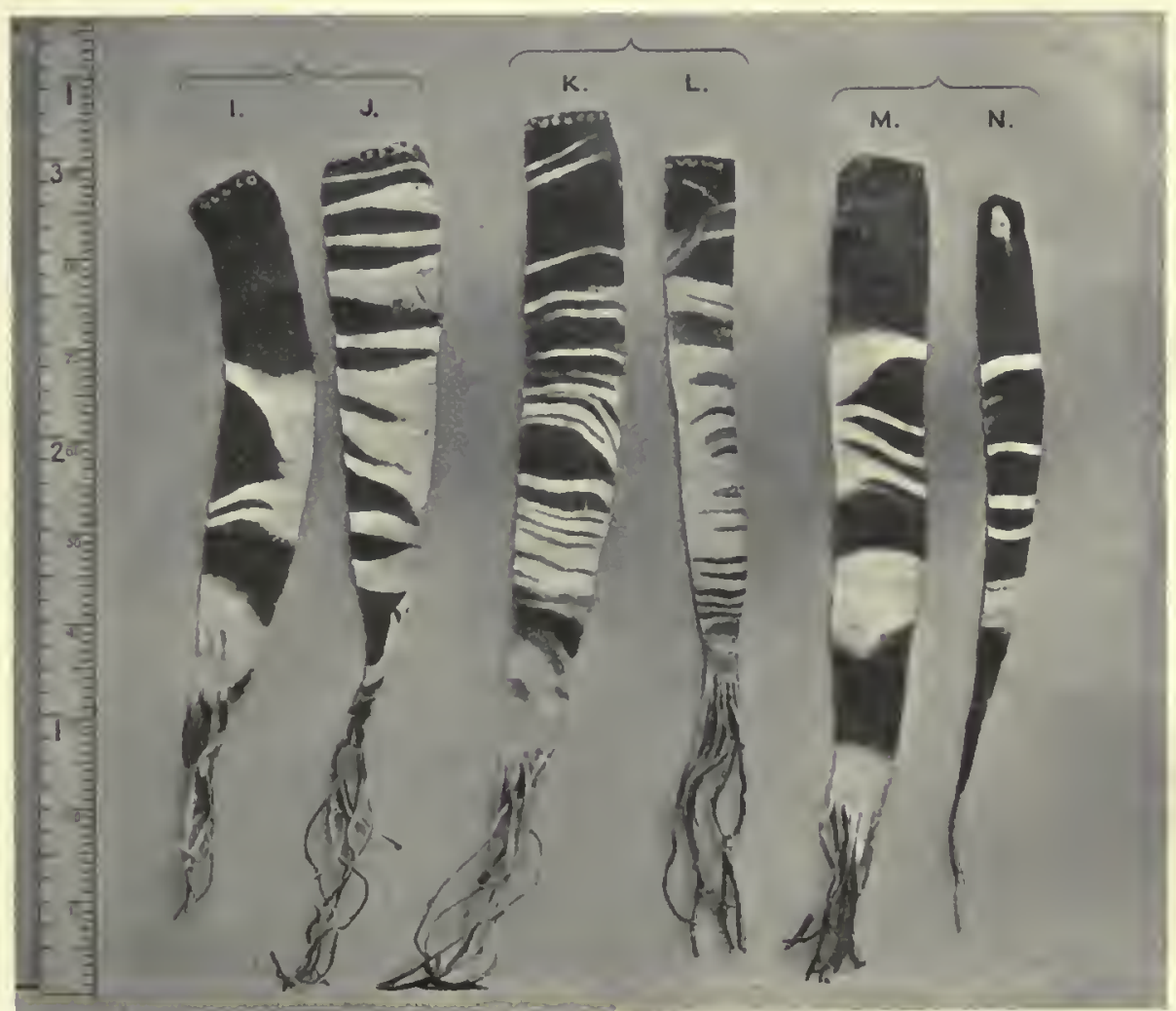

Fig. 2. Bandoliers of Okapi skin, lent by Major Powell-Cotton. 


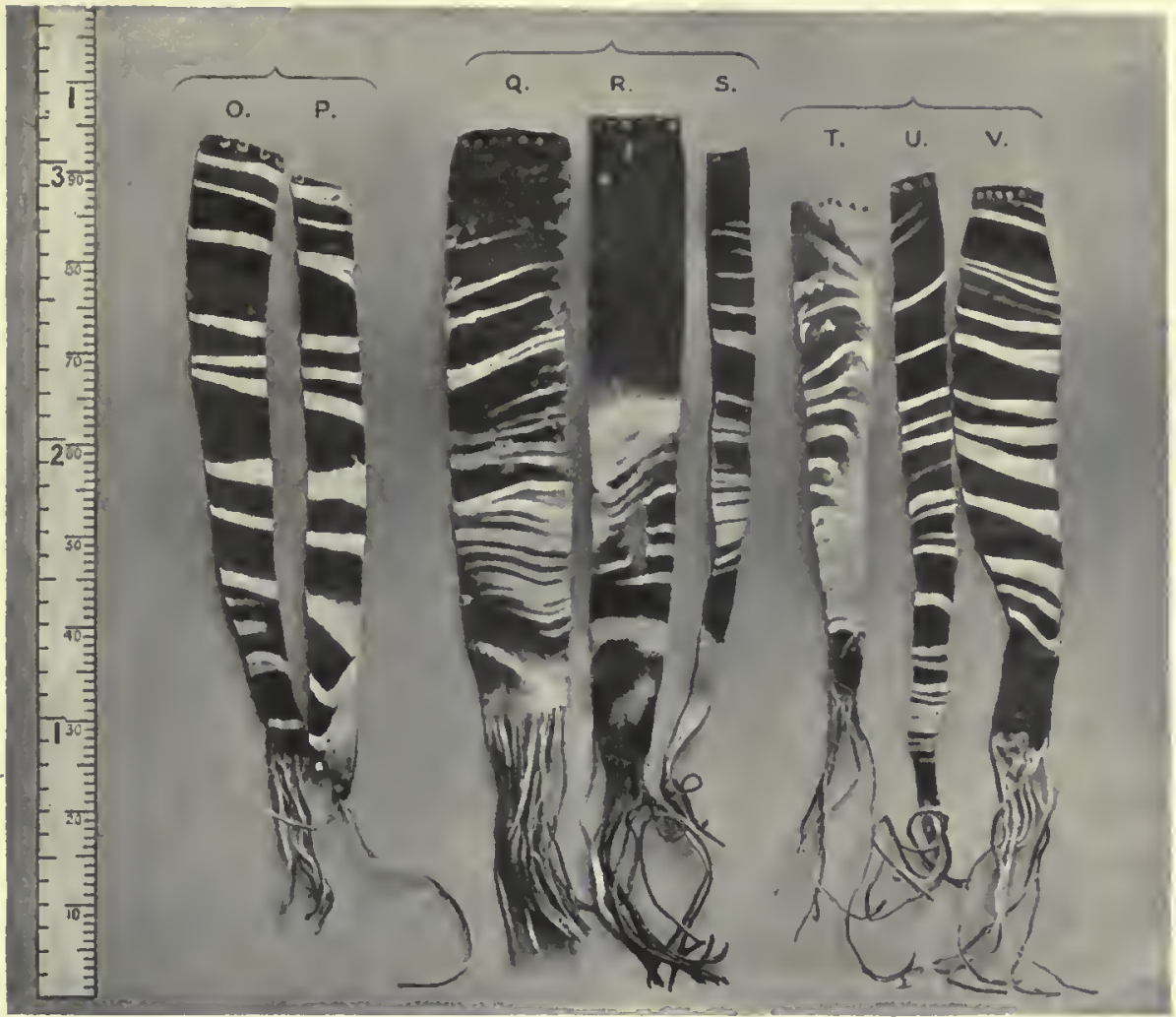

Fig. 1. Bandoliers of Okapi skin, lent by Major Powell-Cotton.

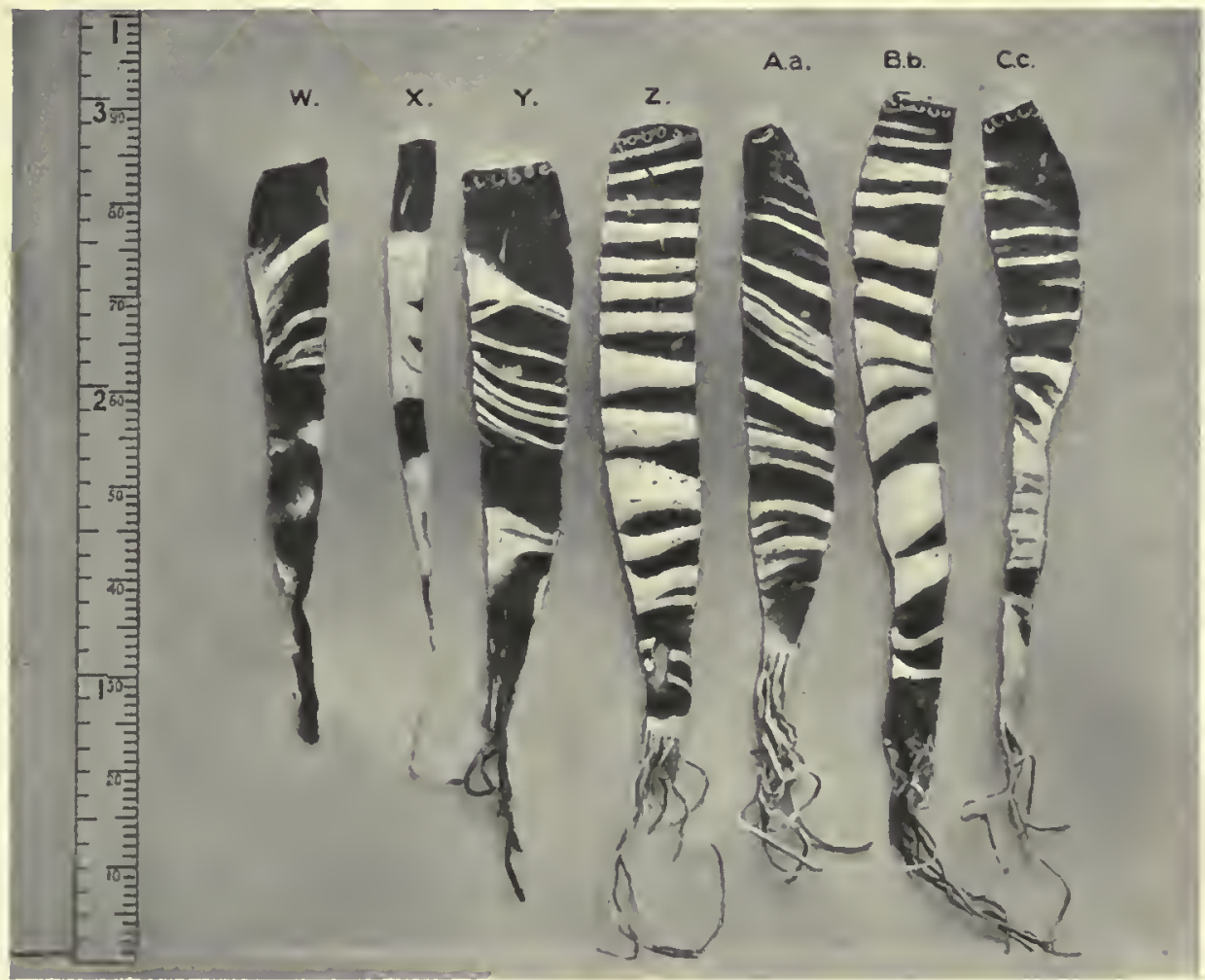

Fig. 2. Bandoliers of Okapi skin, lent by Major Poreell-Cotton. 



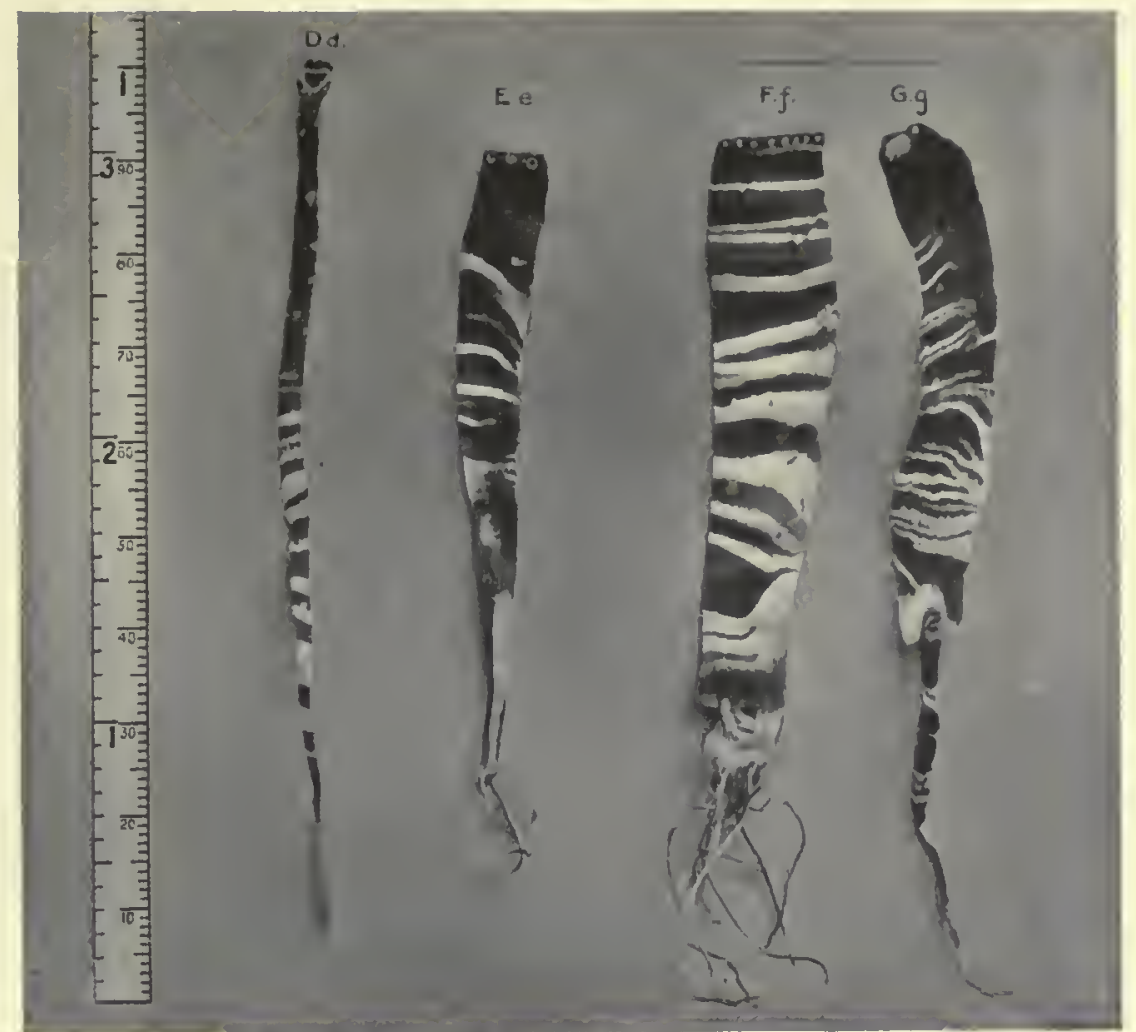

Fig. 1. Bandoliers of Okapi skin, lent by Major Powell-Cotton.

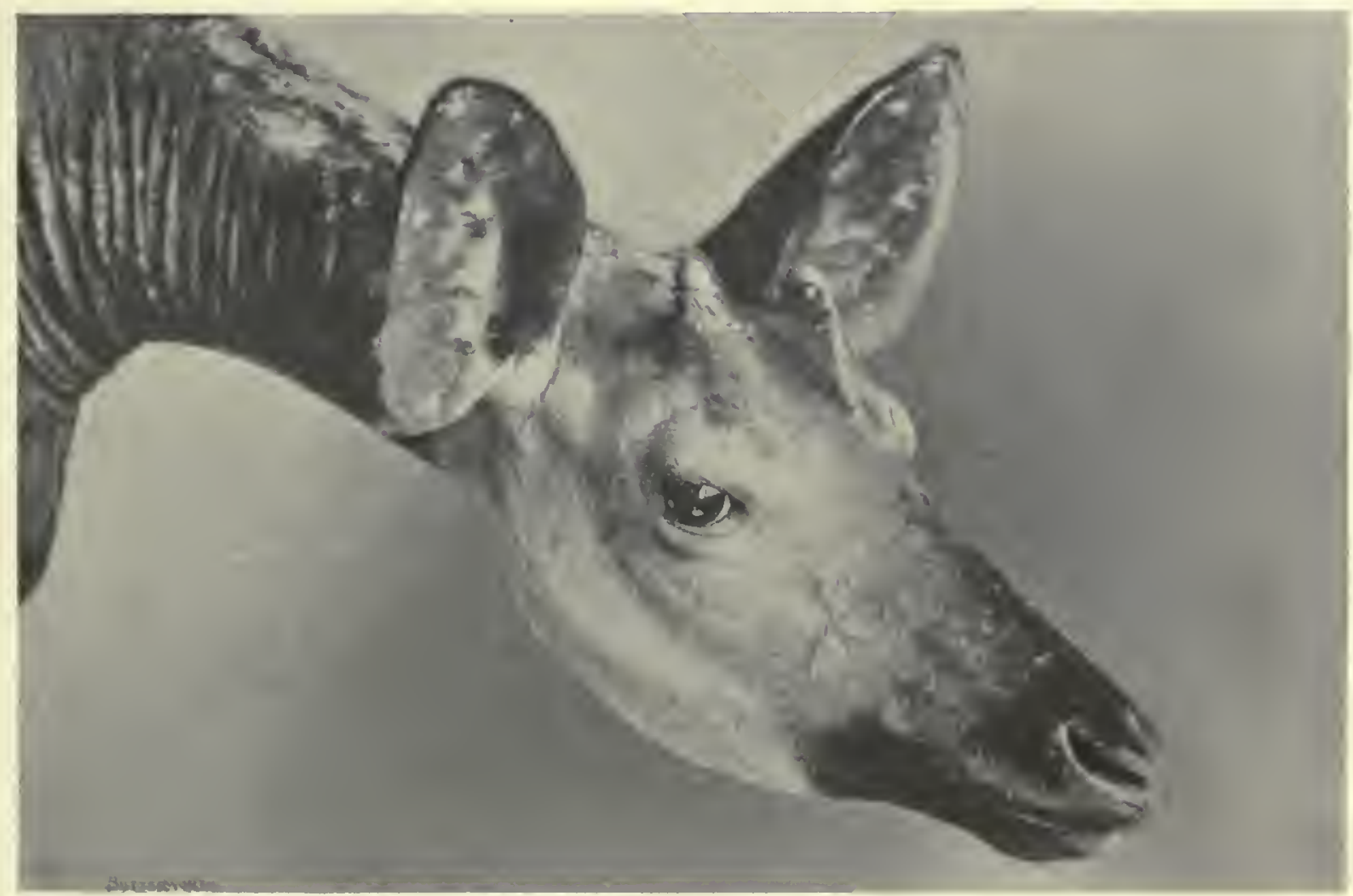

Fig. 2. Head of the specimen in the British Muscum (Natural History) presented by the late Mr. Boyd Alexander, 1907. Young male. Locality: Welle River, ncar the northern border of the Congo Free State. For a side view of the whole animal see Plate 44, fig. 2. 


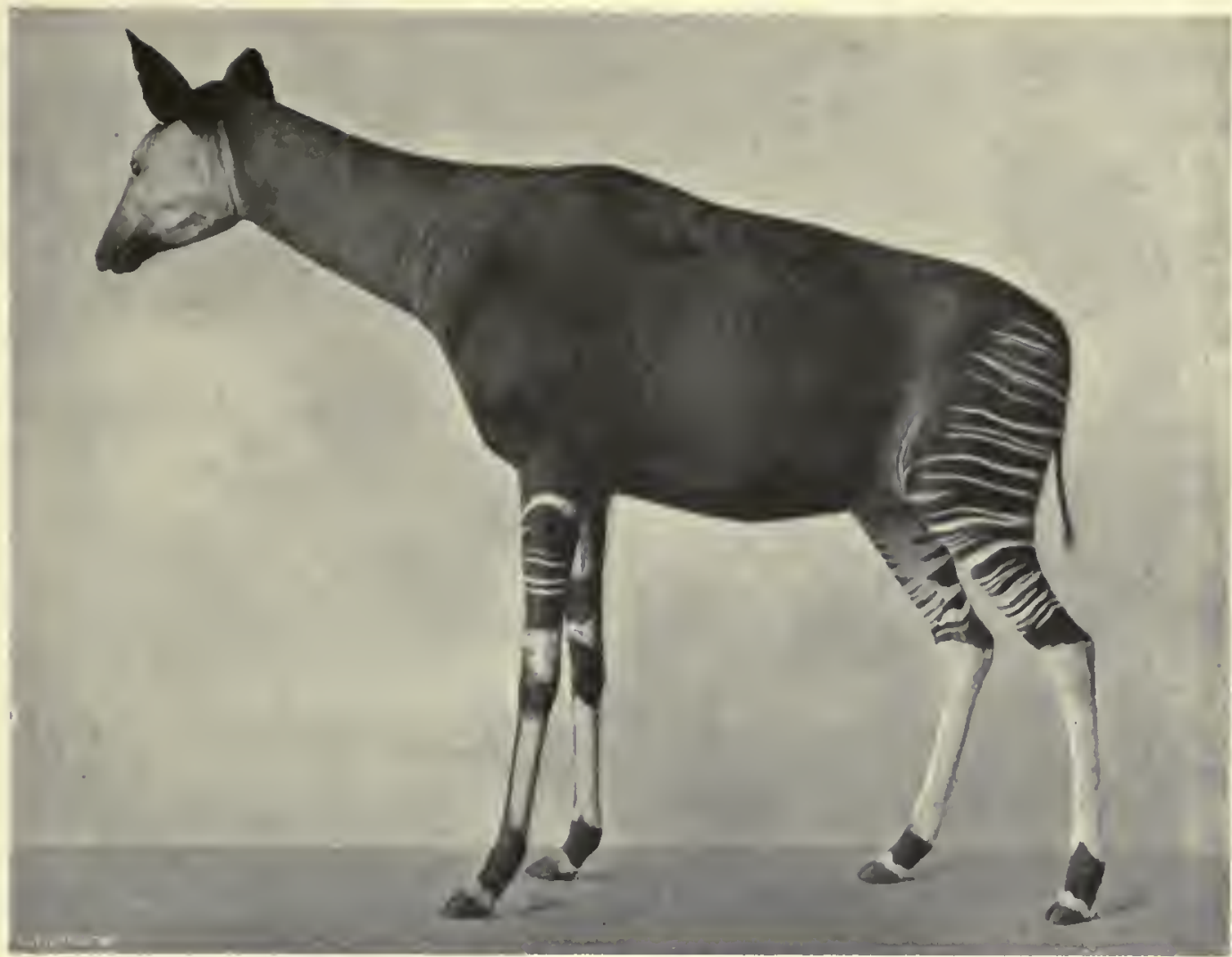

Fig. 1. Specimen in the British Museum (Natural History) presented by Sir Harry Johnston, 1901, who obtained it from Lieutenant Eriksson of the Congo Free State Administration. Sub-adult, sex doubtful. Locality: Semliki Forest, near Lake Albert Edward. A description of this specimen is given in E. Ray Lankester's paper on "Okapia" ("Trans. Zool. Soc.,' 1902, vol. xvi, part vi, pp. 279-314). This skin, with the corresponding skull (Skull $A$ in Plates 3, 8 and 13), is the type of Okapia erikssoni, Lankester ("Ann. Mag. Nat. Hist.," ser. vii, x, 59, November, 1902, p. 417).

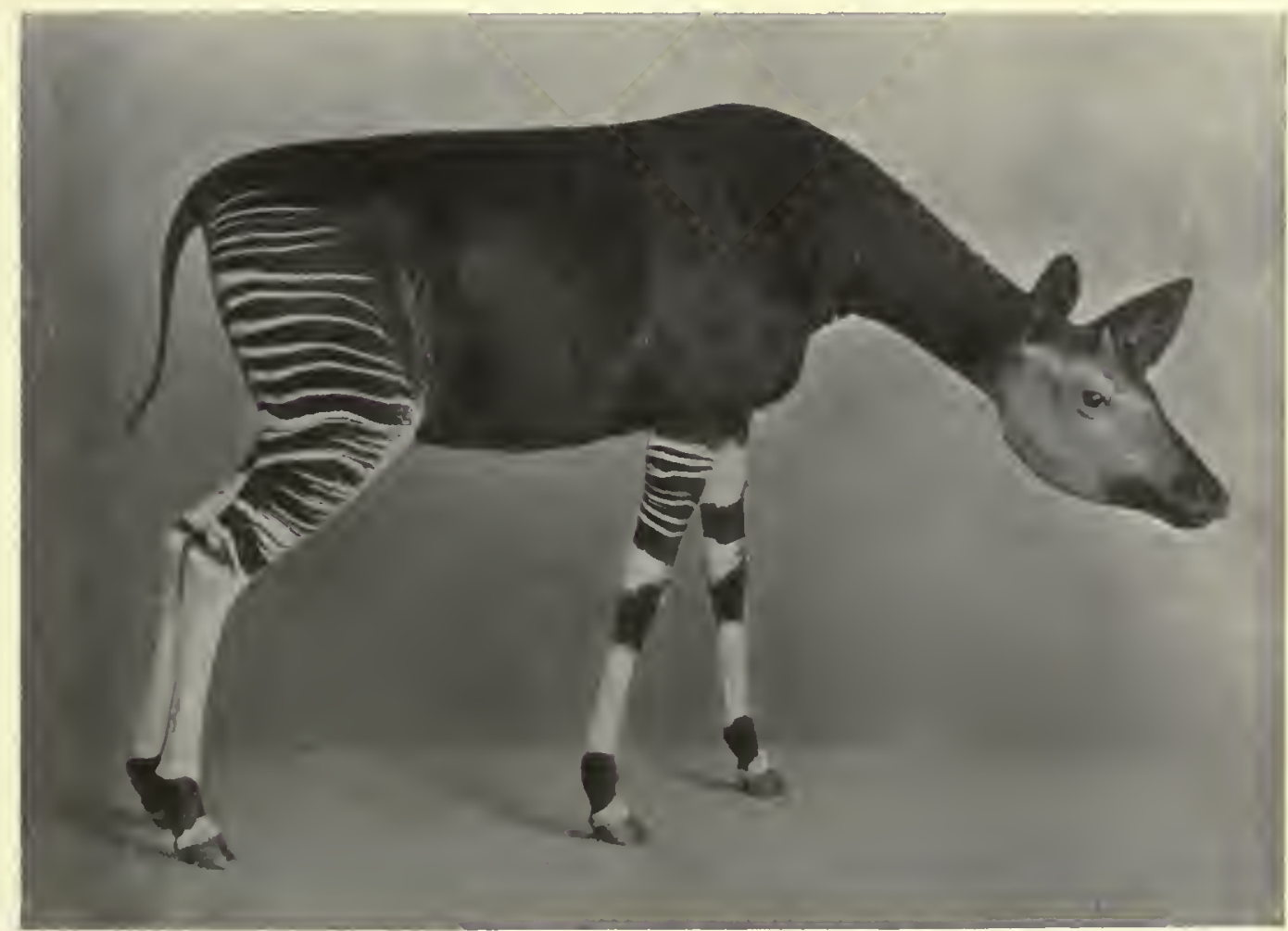

Fig. 2. Specimen in the British Museum (Natural History) presented by the late Mr. Boyd Alexander, 1907. Young male. Loeality: Welle River, near the northern border of the Congo Free State. The head of this specimen is shown also in Plate 43, fig. 2. The skull is that denoted D in Plates 4, 5, 6, 11 and 14. 



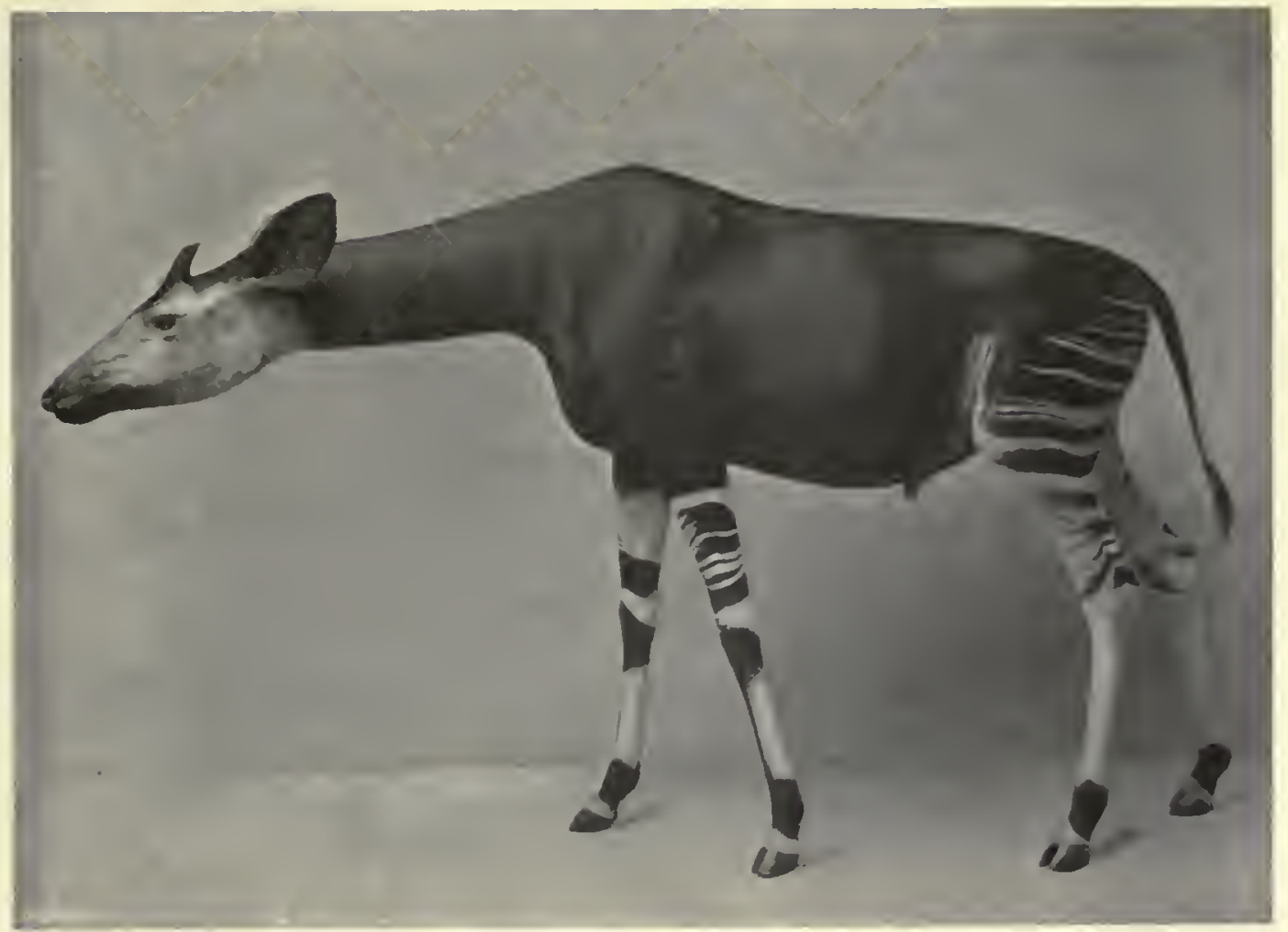

Fig. 1. Specimen in the British Museum (Natural History) presented by Major Powell-Cotton, 1906. Young male. Locality : Ituri Forest, Makala, East Central Africa. Fronn a photograph lent by Major Powell Cotton. The skull of this specimen is that denoted B in Plates 3, 7, 9, 13 and 18; the hinder neck vertebre are figured in Plates 20,23-28.

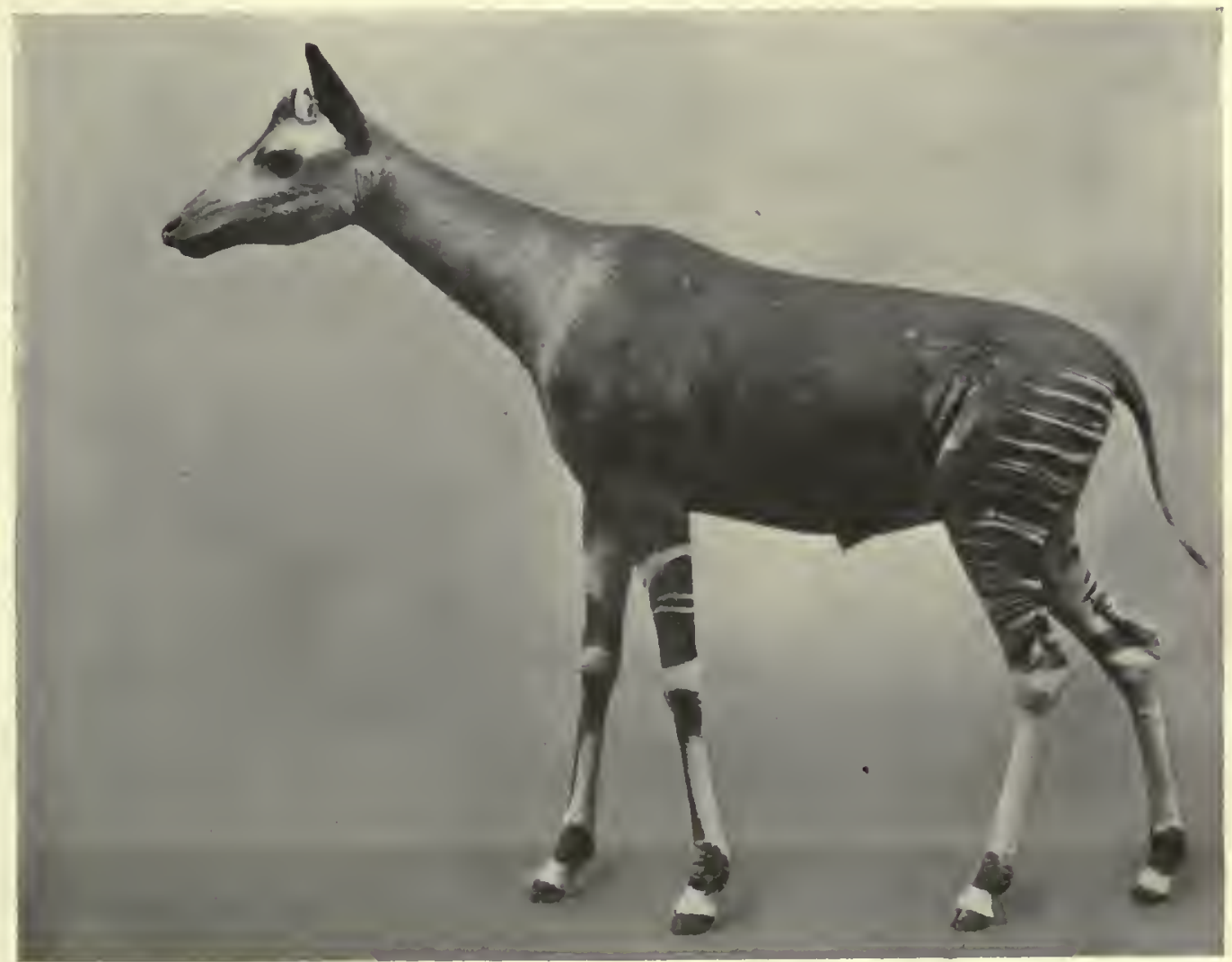

- Fig. 2. Specimen in the Royal Scottish Museum, Edinburgh. Adult, sex doubtful. Locality: Ituri Forcst. From a photograph supplied by Mr. W. Eagle Clarke. The skull of this specimen is that denoted G in Plates 12 and 15. 



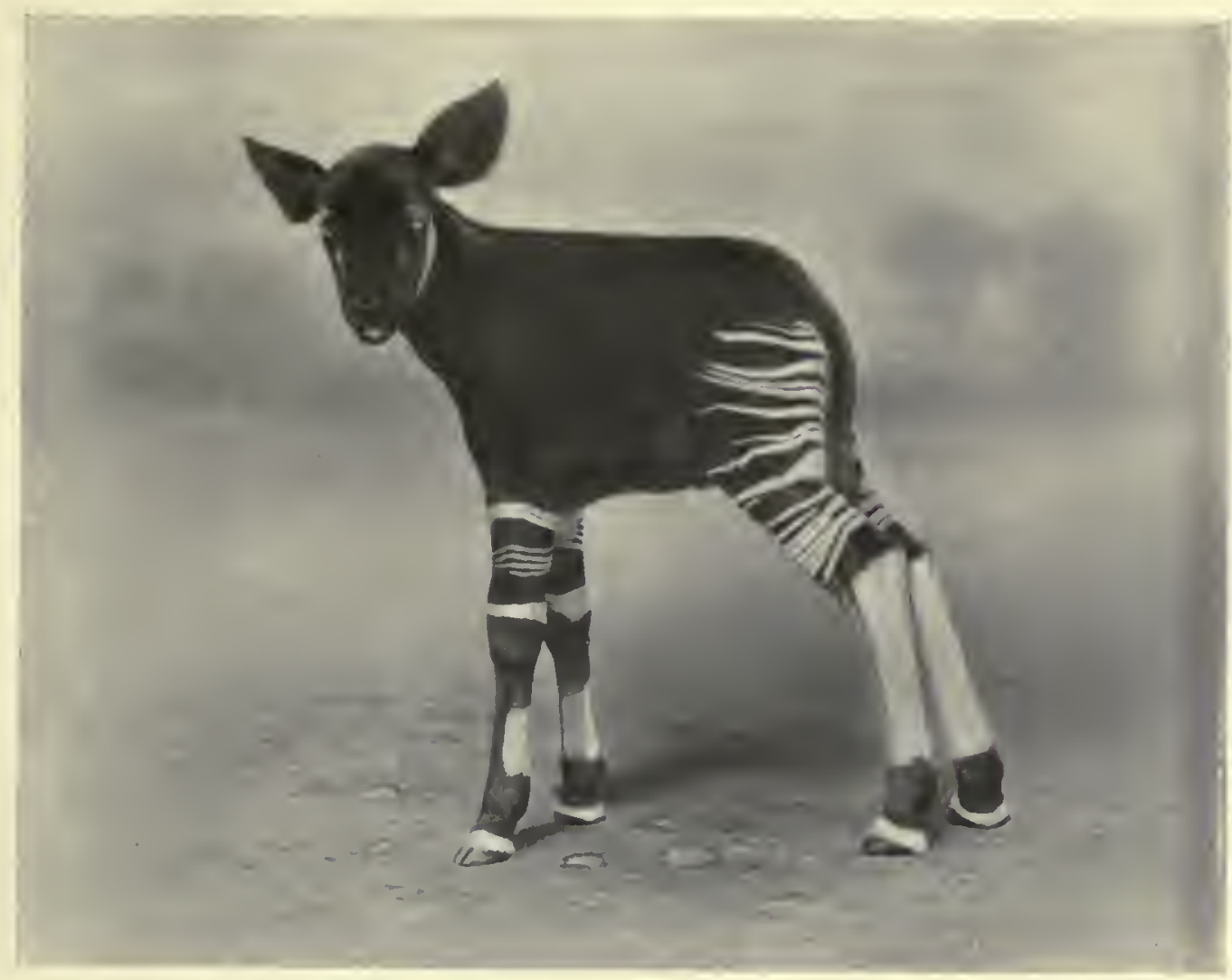

Fig. 1. Photograph of a living Okapi calf, one month old, taken by Monsienr Ribotti, at Bambili. on the Welle River, and sent to Sir Ray Lankester by the Marquis Giacomo Doria, of the Genoa Museum. The photograph was shown at the meeting of the British A ssociation at Leicester on August 5th, 1907, and was reproduced in the 'Illustrated London News' in the issue of September 7th, 1907. The photograph is published also in J. Fraipont's monograph ('A mules du Musée du Congo, Zool.,' ser. 2, vol. i, "Okapia," October, 1907, p. 96, fig. 77), where it is stated to have been taken by Monsieur Lamboray at Angu, Rubi.

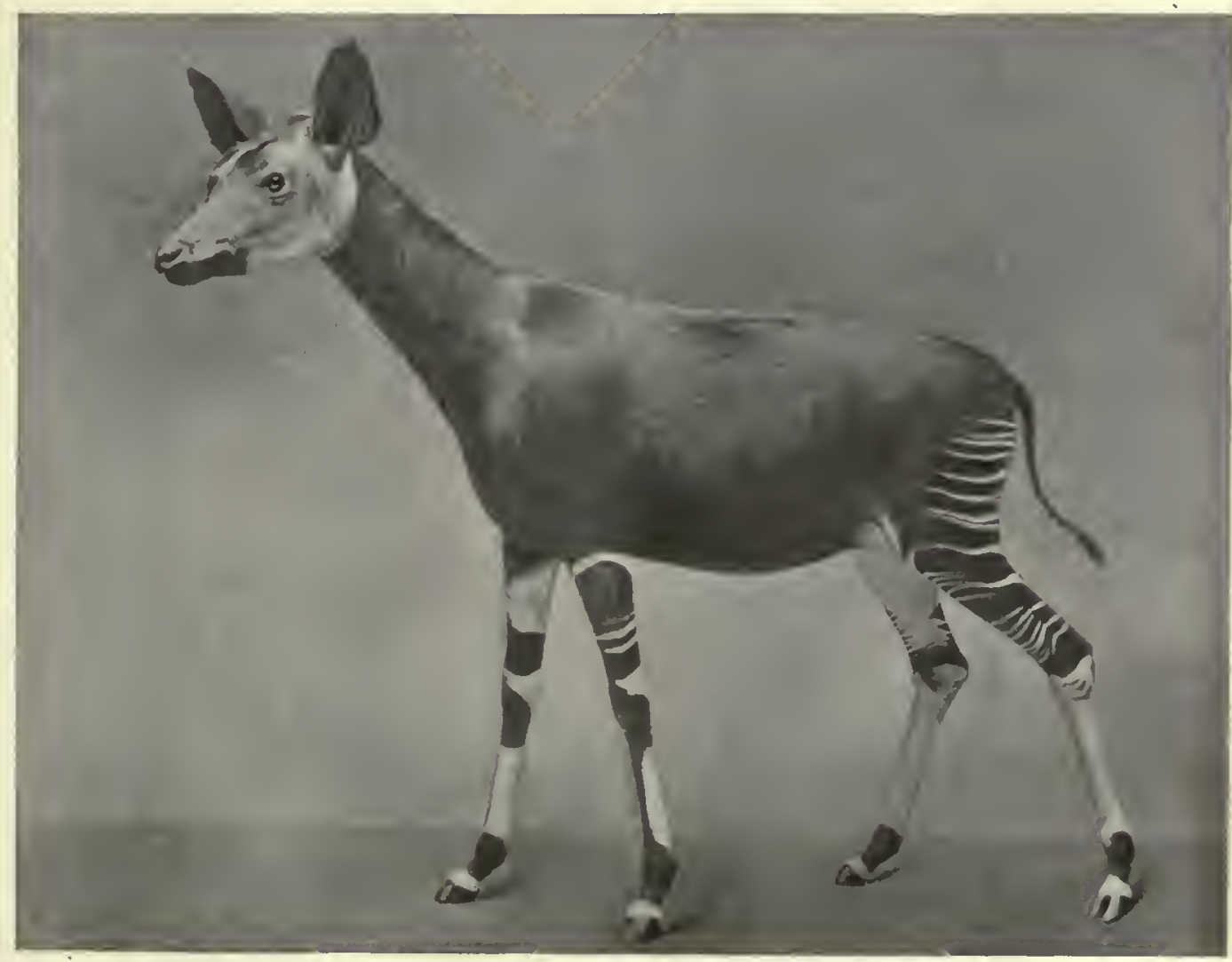

Fig. 2. Specimen in the Hon. Walter Rothschild's museum at Tring. Young, sex doubtful. Locality unknown. From a photograph supplied by Mr. Rothschild. The skull of this animal is that denoted F in Plates 7 and 14 ; the last ccrvical and first dorsal vertebra are figured in Plates 23-28. 


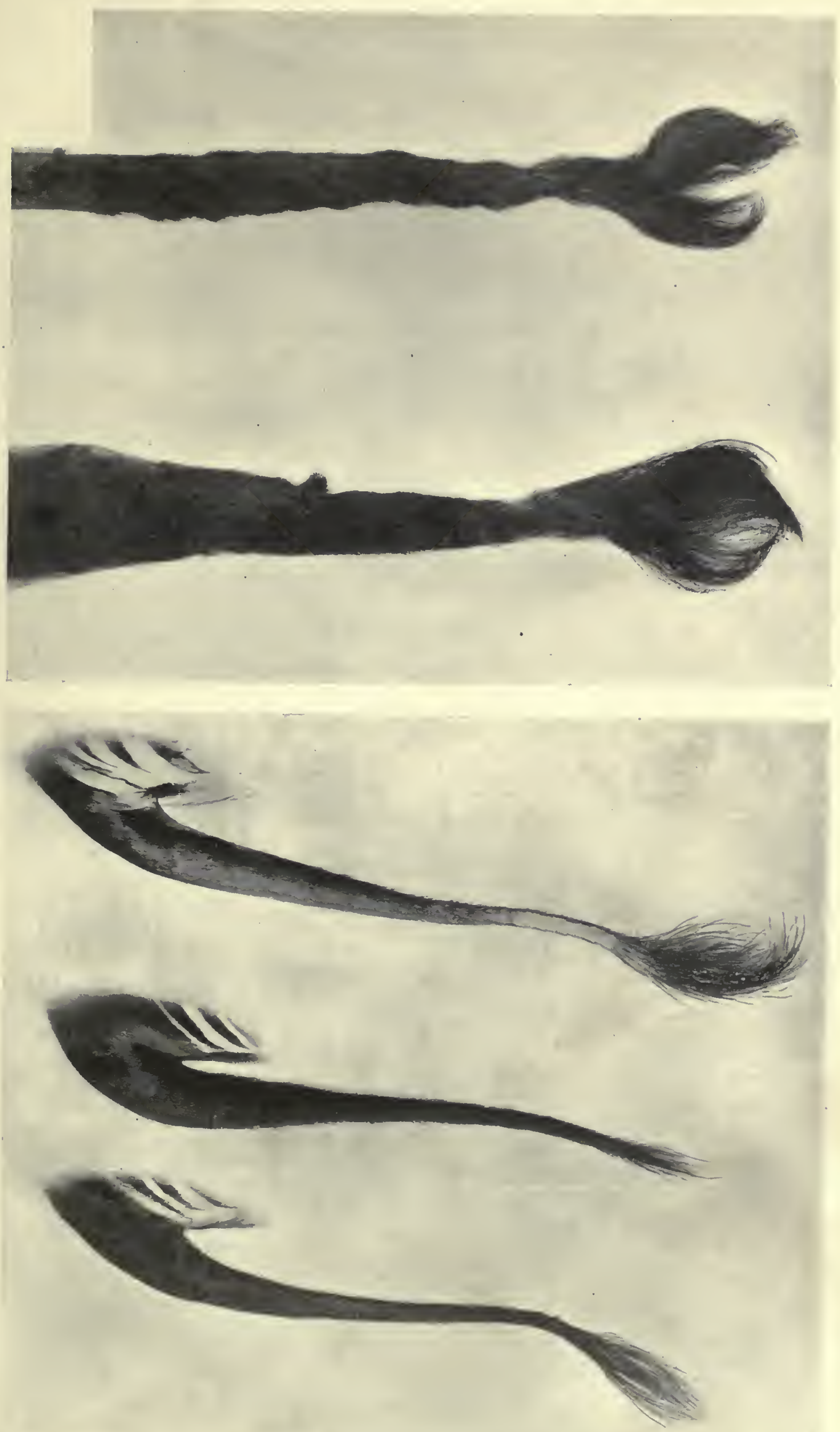

is हे उे हे रे है

इ इ है ङ 至

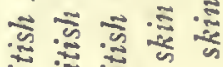

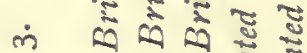
r 0 Q

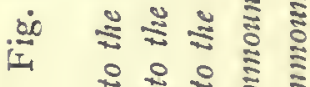
유옻 离 के वे एँ है है है है है ए \#

(i के के के

. $\overrightarrow{\tilde{z}} \tilde{\tilde{z}}=$ $\therefore \sim$ i

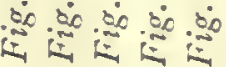




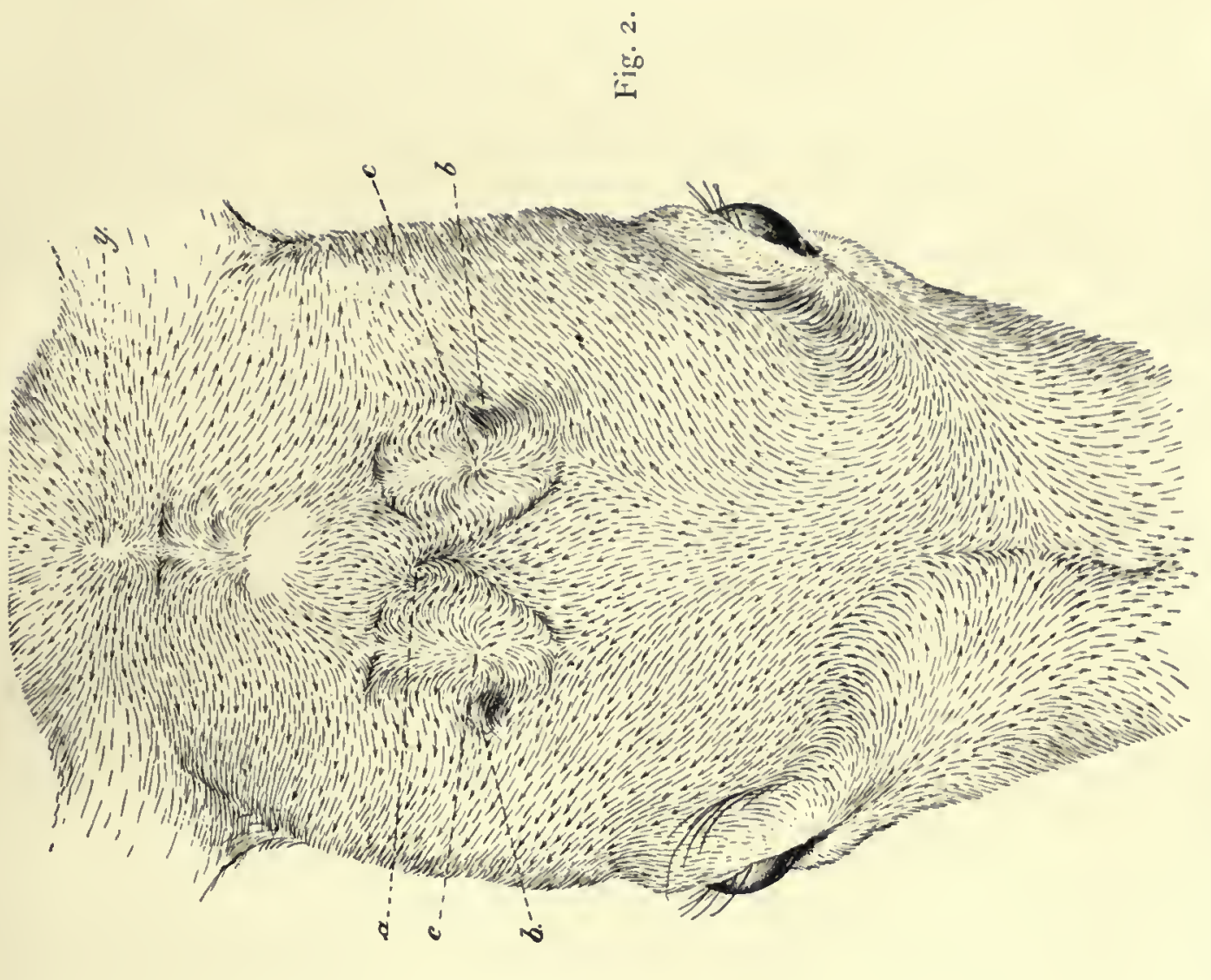

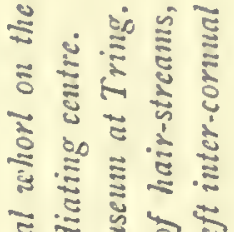

ป气

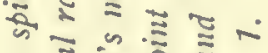

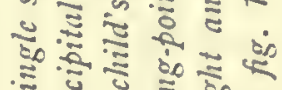

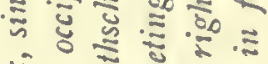

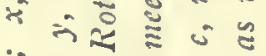

ڤิ)

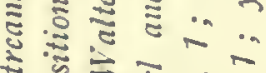

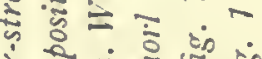

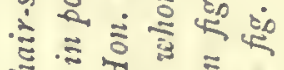

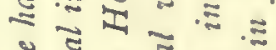

วั้

के

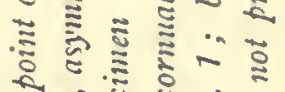

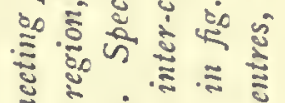

ङ

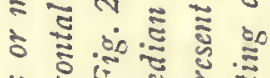

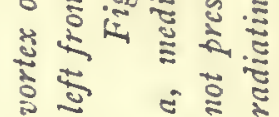

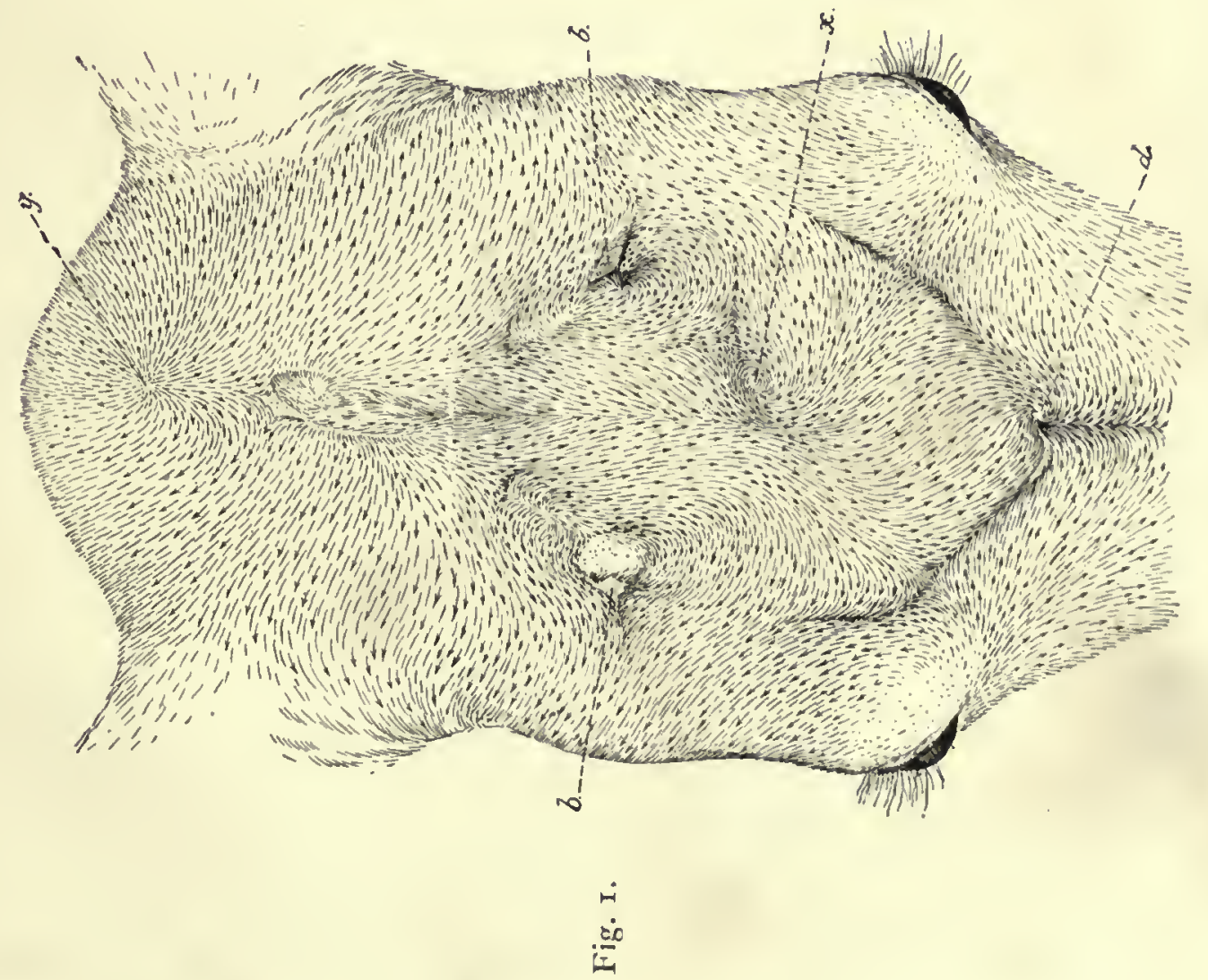

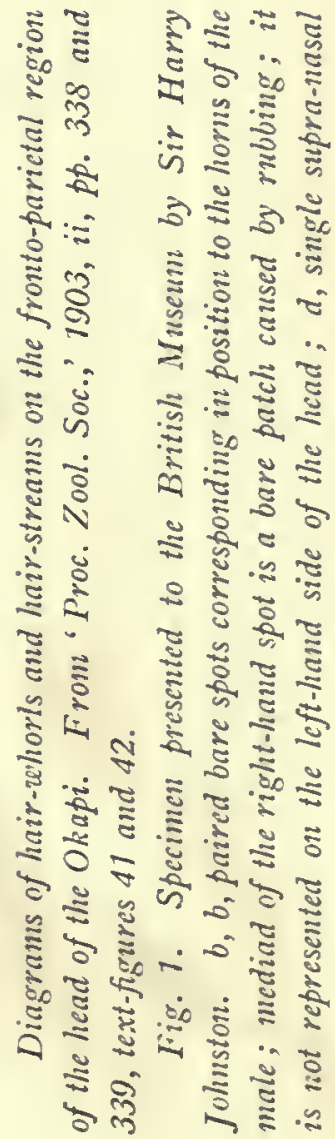


$\because 50=$

. 22

$=84$ 
. 

PLEASE dO NOT REMOVE CARDS OR SLIPS FROM THIS POCKET UNIVERSITY OF TORONTO LIBRARY

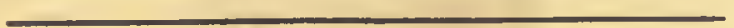

BioMed 
